\title{
Agykérgi szinapszisok összehasonlító vizsgálata és a szinapszisszám változása posztpartum depresszióban
}

\author{
Doktori értekezés
}

Baka Judith

Témavezetők:

Dr. Hajszán Tibor

Magyar Tudományos Akadémia

Szegedi Biológiai Kutatóközpont

Biofizika Intézet
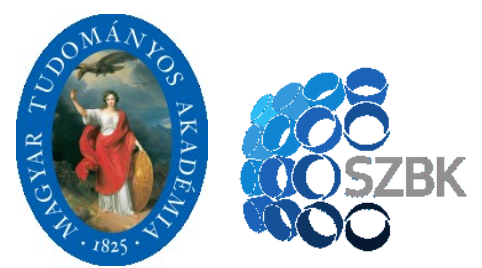

Dr. Tamás Gábor

Szegedi Tudományegyetem

Természettudományi és Informatikai Kar Élettani, Szervezettani és Idegtudományi

Tanszék

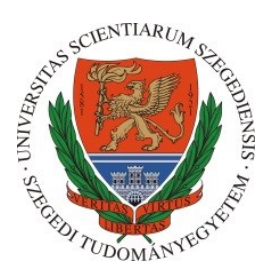

Szegedi Tudományegyetem

Biológia Doktori Iskola

Szeged

2017 
Loch Vilmos emlékére 


\section{TARTALOMJEGYZÉK}

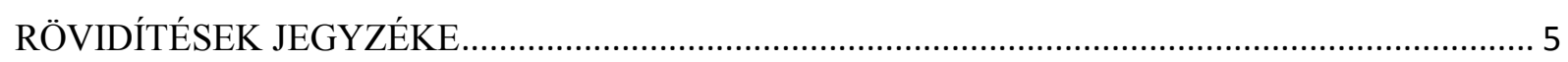

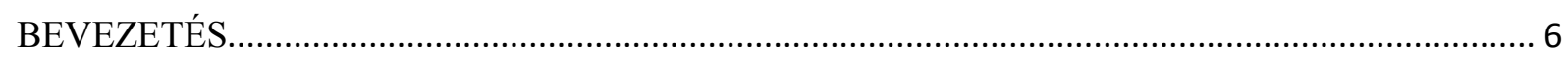

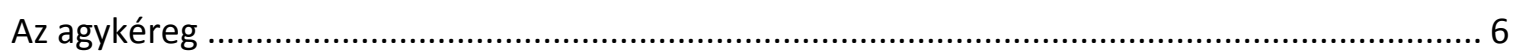

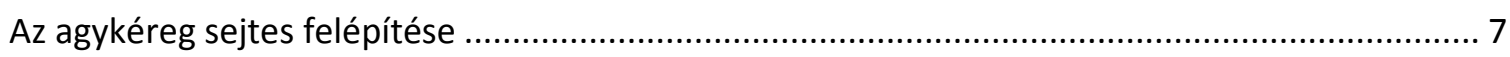

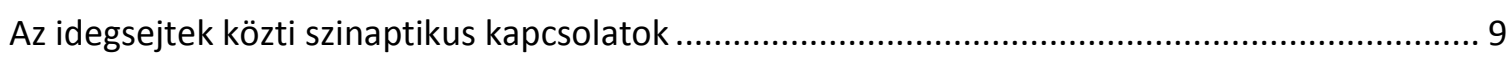

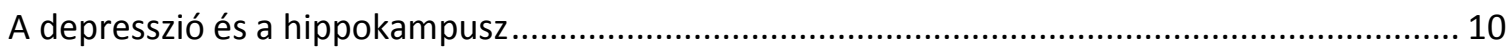

A terhesség utáni (posztpartum) depresszió..................................................................................... 11

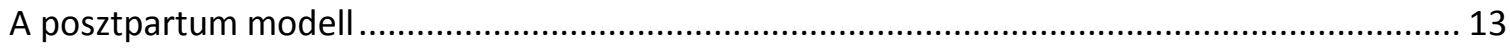

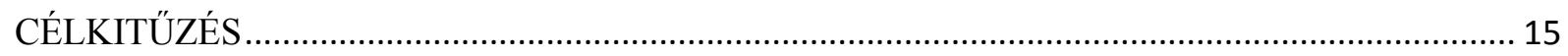

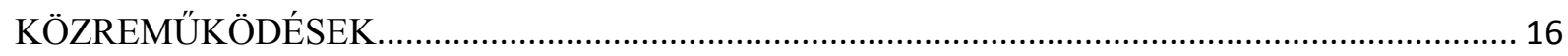

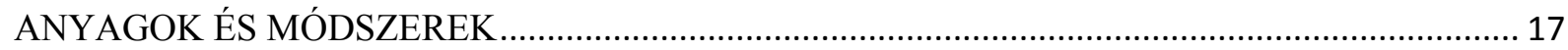

1. Kosársejtekre érkező aszimmetrikus szinapszisok összehasonlitó vizsgálata humán és

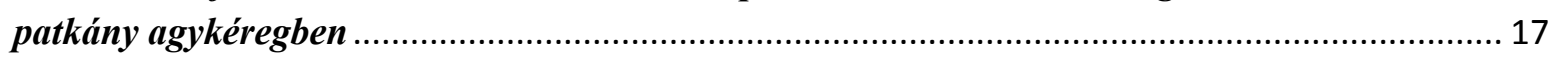

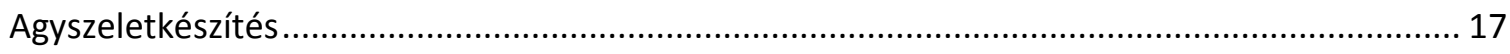

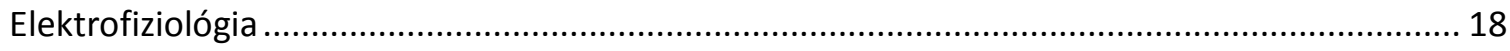

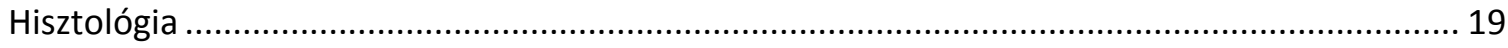

A sejtek azonosítás és háromdimenziós rekonstrukciója............................................................... 20

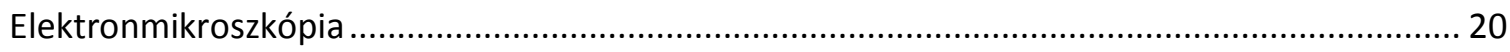

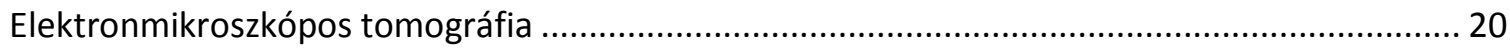

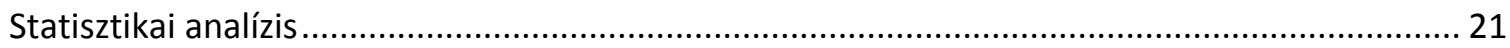

2. A terhesség utáni stressz vizsgálata posztpartum modellen .............................................. 21

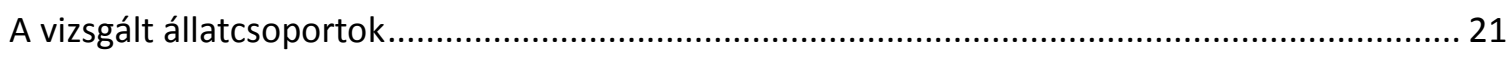

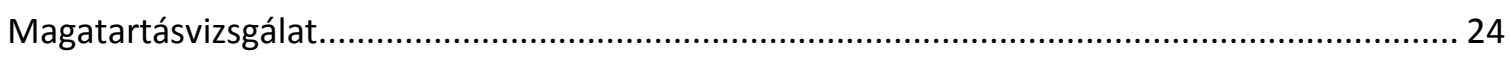

Hisztológia, elektronmikroszkópia és a tüskeszinapszisok számának meghatározása ................... 25

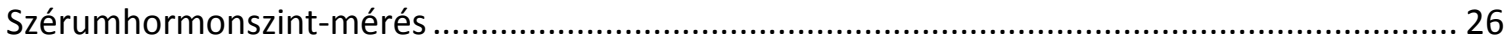

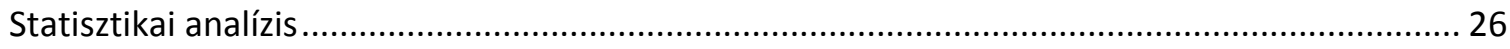

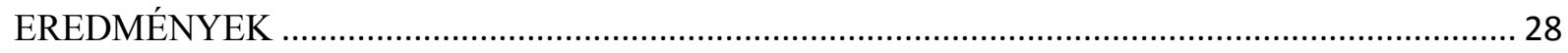

1. Kosársejtekre érkezö aszimmetrikus szinapszisok összzehasonlitó vizsgálata humán és

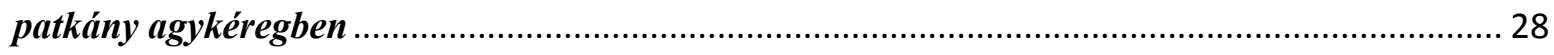

Azonosított piramissejtek és kosársejtek kapcsoltságának fénymikroszkópos vizsgálata............ 28

A kosársejtekre érkező serkentő bemenetek elektronmikroszkópos vizsgálata ........................... 32

2. A terhesség utáni stressz vizsgálata posztpartum modellen ............................................... 36 
A stressz és a megváltozott hormonszintek hatása a magatartásra 36

A stressz és a megváltozott hormonszintek hatása a hippokampális tüskeszinapszisokra 40

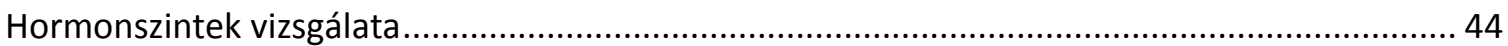

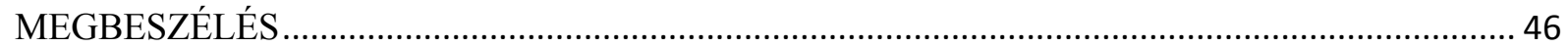

A humán kosársejtekre érkező helyi serkentő szinaptikus bemeneteket multivezikuláris

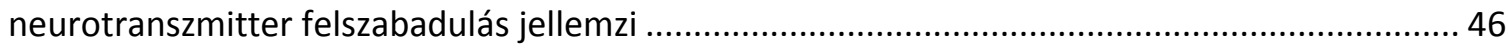

A terhesség utáni stressz szinapszisszám-csökkenést és depressziós viselkedést eredményez ... 48

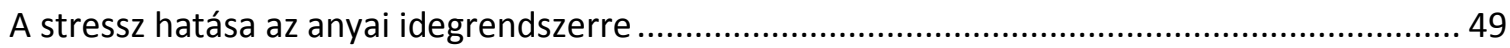

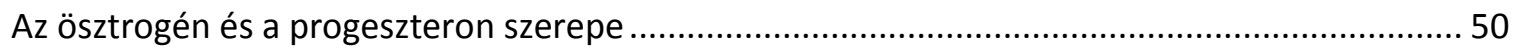

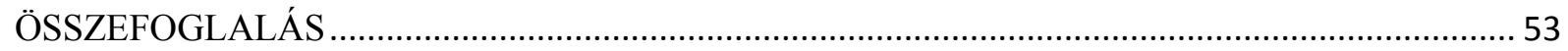

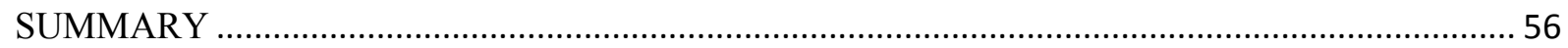

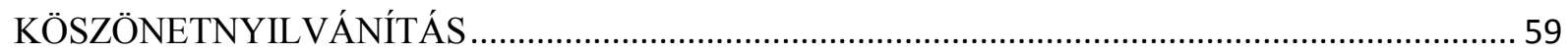

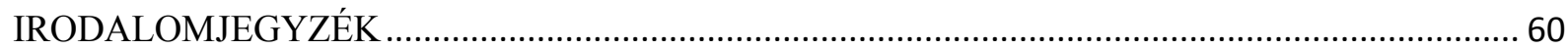




\section{RÖVIDÍTÉSEK JEGYZÉKE}

ABC

AE

ANOVA

AZ

CA

CA1sr

CA3sl/sr

DAB

DG

DGsm

DIC

EIA

EM

EPSC

EPSP

GABA

Horm

HPA

IS

LH

MW U-teszt

NS

PPD

PpD

ProE

TK-teszt

Veh avidin-biotin-komplex

aktív menekülési (active escape) teszt

varianciaanalízis

aktív zóna

Ammon-szarv (Cornu Ammonis)

a hippokampusz Ammon-szarv (Cornu Ammonis) egyes régiójának a stratum radiatum rétege

a hippokampusz Ammon-szarv (Cornu Ammonis) hármas régiójának a stratum lucidum és a stratum radiatum rétege

3'3-diaminobenzidin

gyrus dentatus

a hippokampusz gyrus dentatus régiójának a stratum moleculare rétege

differenciál interferencia kontraszt

enzim immunoassay

elektronmikroszkópia

serkentő posztszinaptikus áram

serkentő posztszinaptikus potenciál

gamma-amino-vajsav

terhesség utáni hormonkezelt csoport

hipotalamusz-hipofizis-mellékvese

elkerülhetetlen stressz (inescapable stress)

tanult tehetetlenség (learned helplessness)

Mann-Whitney U teszt

stresszmentes

terhesség utáni (posztpartum) depresszió

terhesség utáni (hormonmegvont) csoport

proösztrusz csoport

Tukey-Kramer posthoc teszt

kontrollcsoport 


\section{BEVEZETÉS}

Ma már általánosan elfogadott az a tény, hogy a központi idegrendszer az egyedfejlődés során különböző plasztikus változásokon megy át. Több mint 100 évvel ezelőtt Ramón y Cajal már feltételezte, hogy a felnőtt állatok neuronális összeköttetései az idegrendszer működése során változhatnak. Széles körben ismert, hogy a neuronális kapcsolatok fő formája a kémiai szinapszis, amelynek változása és változékonysága a magasabb rendủ fajok idegrendszerének jellemzője. Ezért vizsgálatuk mind az idegrendszer müködése, mind betegségeinek megértése szempontjából alapvető fontosságú.

$\mathrm{Az}$ ezen irányelvek mentén elvégzett vizsgálataink hátteréül az alábbiakban összefoglalom a munkám szempontjából alapvető fontosságú jelenlegi ismereteinket az agykéregről és az agykéreg sejtes szerveződéséről, a szinaptikus kapcsolatokról, a hippokampusz depresszióban betöltött szerepéről és a terhesség utáni (posztpartum) depresszióról.

\section{Az agykéreg}

Az agykéreg a sejtes szerveződés egyik legkomplexebb struktúrája. A központi idegrendszer sejtes felépítését és az idegsejtek szinaptikus kapcsoltságát a XIX. század végén fedezte fel Ramón y Cajal, Golgi-féle festési eljárásának köszönhetően (Ramón y Cajal, 1904, 1911). Az emberi agykérget $10^{10}$ számú idegsejt és ugyanennyi gliasejt alkotja (Bartheld et al., 2016), ami az egész agy sejtes felépítésének a 90\%-a. Az emberi agykéregben az idegsejtek közötti kapcsolatok száma $10^{12}$ és $10^{14}$ között van, nemtől, kortól és egészségi állapottól függően (Mountcastle, 1997; Tang et al., 2001). Az agykéreg az alapvető motoros és érző funkciókon kívül a memóriáért, a tanulásért, az érzelmek kialakulásáért, illetve számos magasabb rendủ funkciókért is felel, mint amilyen a beszéd létrehozása és megértése, a tudat és számos egyéb kognitív folyamat. Ezekért a funkciókért különböző agyi területek felelnek, amit a lokalizált, szelektív sérüléseket követő funkcióvesztéses esetekből ismerünk már a XIX. század eleje óta (Shepherd, 2004).

A Nissl által kifejlesztett festési eljárásnak köszönhetően tudjuk, hogy az idegsejtek eloszlása az ember és más emlősfajok agykérgében rétegesen szerveződött. Brodmann ismerte fel, hogy ez a réteges szerveződés fajspecifikus módon területi különbségeket mutat az 
emlősök agykérgében. Ezek alapján Brodmann az emberi agykérget több mint 40 citoarchitektonikailag különbözö területre osztotta, amelyekről a későbbiekben kiderült, hogy azok funkcionálisan is jól körülírható régiókat alkotnak (Brodmann, 1909; Shepherd, 2004).

Az emlősök között a főemlősök rendelkeznek a legnagyobb aggyal a testtömegükhöz képest. Az emberi agy pedig még ezeken is túltesz (Herculano-Houzel, 2009; DeFelipe, 2011), aminek hátterében nagyrészt a magasabb rendủ kognitív funkciók működésében szerepet játszó asszociációs és prefrontális agykérgi területek relatív súlyának növekedése áll (Shepherd, 2004). A humán és a nem humán fajok között fennálló, az agykéreg felépítésére vonatkozó különbségek nemcsak az eltérő funkciójú területek relatív súlyában nyilvánulnak meg, hanem az agykérget alkotó idegsejtek sürüségében és szinaptikus kapcsoltságukban is. A humán agykéreg egységnyi térfogatában kevesebb idegsejt található, mint az alacsonyabb rendű emlős fajokéban, viszont az egy idegsejtre érkező átlagos szinapszisszám, különösen a kognitív müködésekben szerepet játszó területeken, magasabb, mint más emlős fajokban (Cragg, 1967; DeFelipe et al., 2002; Elston, 2003). Habár a humán és nem humán fajok kognitív képességei között tapasztalt különbségeket leginkább az emberi neokortex, azon belül is, föként a prefrontális kéreg fejlettségének és egyediségének tulajdonítjuk, az anatómiai és méretbeli különbségek ellenére a humán agykérget alkotó egyedi idegsejtek és idegsejthálózatok működéséről keveset tudunk.

\section{Az agykéreg sejtes felépítése}

A központi idegrendszer sejtes felépítését és az idegsejtek szinaptikus kapcsoltságát a XIX. század végén fogadták el Ramón y Cajal, Golgi-féle festési eljárásainak köszönhetően (Ramón y Cajal, 1904, 1911), amivel megdöntötte Gerlach elméletét, miszerint az idegrendszert alkotó idegrostok folytonosak, vagyis egy végtelen, szinciciális rendszert alkotnak. Cajal, az ezüst impregnációs technikával számos idegsejttípust tanulmányozott és nevezett el. Annak ellenére, hogy számos, az agykérget érintő korai anatómiai megfigyelést emberi agykérgen végeztek, az agykérgi sejthálózatok felépítésére és működésére vonatkozó pontosabb ismereteink túlnyomórészt más emlősfajokon, föként rágcsálókon végzett kísérletekből származnak.

Az agykérgi idegsejtek két fő csoportba sorolhatóak a neurotranszmitterük alapján. A nagyobb csoportot alkotó piramissejtek serkentő hatású, glutamát neurotranszmittert 
termelnek. Ez a csoport az idegsejtek körülbelül 80\%-át teszi ki. A másik csoportot az idegsejtek 20\%-át kitevő GABAerg interneuronok változatos típusai alkotják, amelyeket hagyományosan gátló sejteknek tekintünk (Sloper et al., 1979; Winfield et al., 1980; Kawaguchi, 1993; Somogyi et al., 1998; Markram et al., 2004).

A piramissejtek jellegzetes morfológiájúak, ami a szembetűnő, egységesen tüskézett dendritfáról és a kéreg felszíne felé, arra merőlegesen futó, majd a terminális régióban elágazódó vastag apikális dendritről ismerhető fel. Az apikális dendrit mellet számos dendrit ered a sejttest bazális részéről. A piramissejtek másik szembetűnő tulajdonsága, hogy a piramis alakú sejttestük bazális területéről eredő axonjuk fóága a kéreg alatt elhelyezkedő fehérállomány felé veszi az irányt, amely oda kilépve más kérgi valamint kéreg alatti területekre jut el, és azok idegsejtjeivel létesít szinaptikus kapcsolatot. Ezzel szemben a fóágról még a fehérállományba való kilépés előtt leváló oldalágak helyi idegsejtekkel létesítenek szinaptikus kapcsolatokat.

A GABAerg interneuronok kis számuk ellenére igen heterogén csoportot alkotnak. Neurotranszmitterük a gamma-amino-vajsav (GABA), ezért hagyományosan gátló idegsejteknek tekintjük őket. Azonban az utóbbi években kiderült, hogy az e sejtek kis hányadát képező axo-axonikus sejtek akár serkentő hatásúak is lehetnek (Szabadics et al., 2006). Egyes GABAerg sejtek szinaptikus kapcsolatrendszerei, valamint morfológiai, elektrofiziológiai és molekuláris jellemzőik jól korrelálnak, így ezek alapján osztályokba rendezhetőek (Kawaguchi \& Kubota, 1993, 1996, 1997). Alakjuk változatos, nincs kitüntetett apikális dendritjük, axonjuk pedig jellemzően ugyanabban a kérgi régióban szinaptizál, amelyben a sejttest és a dendritek is találhatók. A GABAerg sejtek legnagyobb százalékát a Ramón y Cajal által elnevezett kosársejtek alkotják (Markram et al., 2004). A kosársejtek sima, tüskézetlen dendritü heterogén sejtpopulációt alkotnak, melyek jellemzően a piramissejtek sejttestét (szóma) és proximális dendritjeit idegzik be (Somogyi et al., 1983; Kisvárday et al., 1993; Freund \& Katona, 2007). Gyors membrán-időállandójuknak köszönhetően, a rájuk érkező serkentő bemenetek gyorsan és viszonylag nagy precizitással kelthetnek akciós potenciált bennük (Fricker \& Miles, 2000; Galarreta \& Hestrin, 2001). Egymással kölcsönös rés- és szinaptikus kapcsolatokat alkotva a kosársejtek hatékonyan szinkronizálják egymást, és milliszekundumos pontossággal időzítik posztszinaptikus sejtjeik müködését (Galarreta \& Hestrin, 1999, 2001; Gibson et al., 1999; Tamás et al., 2000, 2004). 


\section{Az idegsejtek közti szinaptikus kapcsolatok}

Agyunk fő feladata, hogy a külső és belső környezetből érkező, folyamatosan változó és hatalmas mennyiségü információt feldolgozza, tárolja és arra megfelelö választ adjon. Ezen feladatok ellátását az idegsejtek és a köztük lévő szinaptikus kapcsolatok változatossága és plaszticitása teszi lehetővé. Az agykérgi idegsejteken 5000 - 60000 szinapszis is lehet (Cragg, 1967; DeFelipe \& Fariñas, 1992). Ezeket a kapcsolatokat elöször Held és Auerbach anilinfeséssel mutatta ki, amit Sherrington szinapszisnak nevezett el, és definiálta, mint azt a struktúrát, ahol az idegimpulzus az egyik sejtről a másikra terjed. A szinapszison keresztüli jelátvitelt Castillo és Katz tanulmányozta és írta le mint a szinaptikus transzmisszió ma már széles körben elfogadott kvantális modelljét (del Castillo \& Katz, 1954), melynek azóta az anatómiai hátterére is fény derült. A neurotranszmitter a preszinaptikus sejt axonterminálisaiban vezikulumokban raktározódik. A szinaptikus transzmisszió folyamán ezek a vezikulumok szabadítják fel a bennük lévő neurotranszmittert, ami a szinaptikus résbe ürülve a posztszinaptikus sejten fejti ki hatását. A felszabadításra váró vezikulumok a preszinaptikus aktív zónához (AZ) horgonyzódnak (dokkolt vezikulák), és az akciós potenciál hatására exocitózissal ürülhetnek. Ezek a vezikuláris neurotranszmitter-csomagok okozzák a szinaptikus transzmisszió kvantális természetét.

Az agykérgi piramissejtek glutamáterg szinapszisaikkal serkentik a helyi gátló sejteket. A legszélesebb körben alkalmazott rágcsáló-modellállatokon már több tanulmány is készült ezen kapcsolatok müködéséről (Ali et al., 1998; Holmgren et al., 2003; Brecht, 2012). Ezek a szinaptikus kapcsolatok átlagosan 1-4 mV amplitúdójúak, melyek általában egyedül nem képesek a posztszinaptikus interneuronon akciós potenciált kiváltani. Ezzel ellentétben, az emberi agykéregben ugyanezen szinapszisok jóval hatékonyabbak is lehetnek: egy piramissejt egyetlen akciós potenciálja képes lehet a környező gyorsan tüzelő interneuronokat nyugalmi membránpotenciáljukról küszöb fölé depolarizálni és akciós potenciálba vinni (Molnár et al., 2008). A hatékony serkentés hatására poliszinaptikus hálózatok aktiválódnak, amelyek a Hebb-féle hálózatok alapjául szolgálhatnak (Hebb, 1949; Molnár et al., 2008). 


\section{A depresszió és a hippokampusz}

A major depresszió súlyos mentális betegség (Belmaker, 2008), amely minden ötödik ember életében legalább egyszer előfordul (Kessler et al., 1994). A Világegészségügyi Szervezet (WHO) szerint a depresszió fokozatosan a második legnagyobb népegészségügyi problémává válik a fejlett világban. Mindamellett, hogy különféle társbetegségek (kardiovaszkuláris betegségek (Carney et al., 2002), demencia (Kanner, 2005)) kialakulásának gyakoriságát növeli, a depressziós betegek 15\%-a öngyilkosságba menekül. Az is bizonyított, hogy az öngyilkosságok $70 \%$-át kezeletlen vagy nem megfelelöen kezelt depressziós állapotban követik el.

A betegség kialakulását leggyakrabban valamilyen élethelyzeti stresszhatás váltja ki (Kendler et al., 1999; McEwen, 2003). A depresszióhoz vezető neurobiológiai folyamatok részletei viszont mindmáig tisztázatlanok, akárcsak az antidepresszánsok pontos terápiás hatásmechanizmusai. A ma elérhető antidepresszáns gyógyszerek (Trivedi et al., 2006) farmakológiai hatása szinte kizárólag a 60 éves monoamin hipotézisre épül (Loomer et al., 1957). Ennek értelmében a depresszió tüneteiért a szerotonin-, az adrenalin/noradrenalin- és a dopamin rendszerek müködési zavarai, illetve ezen neurotranszmitterek elégtelen mennyisége a szinaptikus jelátviteli folyamatokban a felelős. Ez a teória azonban nem ad magyarázatot arra az időeltolódásra, ami a farmakológiai és a terápiás válasz között telik el, mivel az antidepresszánsok a monoaminok szintjét azonnal megemelik, viszont a hangulat stabilizálódása csupán hetekkel később tapasztalható. Ezen megfigyelések hatására az elmúlt években számos alternatív hipotézis született a depresszió kiváltó okával kapcsolatban, melyekben többek között felmerült az NMDA receptorok és a glutamáterg transzmisszió lehetséges szerepe (Palucha \& Pilc, 2005). Az agyi képalkotó vizsgálatok, valamint a postmortem szövettani elemzések arra utalnak, hogy az érzelmekért felelös agyterületekhez köthető a depresszió kialakulása. A depressziós betegek számos kognitív- és memóriatünetet mutatnak, főként a szelektív figyelem és az explicit memória terén. A hippokampusz az egyik legfontosabb központ a memória szerveződésében, mivel az információfeldolgozás és az érzelmek, illetve a deklaratív memóriát szabályozó neuronális kör része. A depressziós egyénekben csökkent volumenű hippokampuszt írtak le (Manji et al., 2001; Price \& Drevets, 2010).

A hippokampusz, ahogy az egész agykéreg is, lamináris szerveződésü. A principális sejtjei két morfológiai csoportot alkotnak. A gyrus dentatus (DG) stratum granulosum 
rétegében találhatóak az úgynevezett szemcsesejtek sejttestei, amelyek ahogyan a piramissejtek is, sürün tüskézett dendrittel és glutamát neurotranszmitterrel rendelkeznek. A másik fö serkentő sejt a piramissejt, amely sejttestje az Ammon-szarv (CA) stratum pyramidale rétegben helyezkedik el. A további rétegek a principális sejtek dendritszakaszait tartalmazzák. A hippokampusz sejtjei az úgynevezett triszinaptikus körben kommunikálnak egymással aszimmetrikus tüskeszinapszisokon keresztül (Andersen et al., 1971). Ennek első tagja az úgynevezett perforáns pálya, ahol az entorhinális kéregből érkező serkentő rostok a szemcsesejtek gyrus dentatus stratum moleculare-ba (DGsm) nyúló tüskézett dendritjein végződnek (Blackstad, 1958; Witter, 1993). Ezt az információt a szemcsesejtek axonjai továbbítják a CA3 piramissejtjeinek a stratum lucidum (CA3sl) rétegben lévő speciális dendrittüskéire (Claiborne et al., 1986), majd innen a piramissejtek Schaffer-kollaterálisain keresztül az információ a CA1 piramissejtjeinek stratum radiatum (CA1sr) területén lévő dendrittüskéire érkezik, és végül ezen sejtek axonjain keresztül jut ki a hippokampuszból.

A major depresszió patomechanizmusának egyik fő komponense a hippokampusz müködésének rendellenessége (Nestler et al., 2002). A rendellenes müködéssel együtt jár a hippokampusz térfogatának csökkenése, a hippokampális neurogenezis hanyatlása és a fent említett triszinaptikus kört alkotó tüskeszinapszisok számának csökkenése, amelyek hatékony antidepresszáns-kezelésekkel visszafordíthatóak vagy megakadályozhatóak (Sheline et al., 2003; Duman \& Monteggia, 2006; Hajszan et al., 2009). Habár a legutóbbi kutatási eredmények beszámolnak a hippokampusz anyai stressz indukálta strukturális változásairól (Green \& Galea, 2008; Pawluski et al., 2016), közvetlen elektronmikroszkópos bizonyítéka a hippokampusz szinaptikus változásainak posztpartum depresszióban jelenleg nem ismert. Figyelembe véve a major depresszióban már jól ismert szinaptikus elváltozásokat, a posztpartum depresszió kínálkozó lehetőséget biztosított, hogy szinaptikus vizsgálatainkat kiterjesszük azok klinikai aspektusaira is.

\section{A terhesség utáni (posztpartum) depresszió}

Számos tanulmány számolt be arról, hogy a tartós stressz a terhesség alatti időszakban szorongásos viselkedést okoz a szülést követően (Darnaudéry et al., 2004; Smith et al., 2004; O’Mahony et al., 2006; Brummelte \& Galea, 2010; Hillerer et al., 2011). A terhesség alatti stresszel ellentétben, a terhesség utáni közvetlen stressz hatását kevésbé vizsgálták, holott a 
szülés utáni időszakban az újszülött szükségleteinek a kielégítése komoly stresszforrás lehet az anya számára. Kutatócsoportunk korábbi eredményei azt mutatták, hogy már a petefészek eltávolításával, vagyis a nemi hormonok megvonásával is enyhe depresszív magatartás következhet be (Hajszan et al., 2010). Ezért kíváncsiak voltunk, hogy a stressz és a nemi hormonok milyen kapcsolatban állhatnak, és azok hogyan hatnak egy terhességi/posztpartum modellben.

A depresszió és a szorongás a terhesség utáni időszak gyakori szövődménye. A szülést követő első három hónapban az anyák 15\% -a szenved a terhesség utáni depresszióban (PPD) (American Psychiatric Association, 2000; Gavin et al., 2005; O’Hara \& Wisner, 2014). A tünetek többsége megegyezik a major depresszió tüneteivel. Ilyenek többek között az érzelmi ingadozások, a kognitív funkciók károsodása, a gyakori büntudat és az elégedetlenség érzése (Melges, 1968; Pitt, 1968; Laura J. Miller, 2002; Crawley et al., 2003; O’Hara \& Wisner, 2014). Extrém esetekben ez a megbetegedés az anya öngyilkosságához vagy akár a gyermek meggyilkolásához vezet (Pariser et al., 1997; Spinelli, 2004). Ez a legextrémebb megnyilvánulása annak a ténynek, hogy a PPD az egész családot érintő betegség, ami a kognitív és a pszichoszociális deficiteken keresztül az utódok fejlődésére is hatással van (Grace et al., 2003; Nomura et al., 2006; Letourneau et al., 2012; Verbeek et al., 2012).

Hasonlóan a major depresszióhoz (McEwen, 2003) epidemiológiai kutatások kimutatták, hogy a PPD fő kockázati tényezője a stressz (Lancaster et al., 2010; Davey et al., 2011; Stewart, 2011; Hillerer et al., 2012). Humán felmérések (Moses-Kolko et al., 2014) és rágcsálókon végzett kísérletek (Gemmel et al., 2016; Haim et al., 2016; Pawluski et al., 2016) is bizonyítják azt a tényt, hogy a stressznek idegrendszert befolyásoló hatása van a terhesség alatti időszakban, ugyanis a terhesség alatti folyamatos stressz szorongásos viselkedést és a szülői gondoskodás hiányát eredményezte a terhesség után (Darnaudéry et al., 2004; Smith et al., 2004; Brummelte \& Galea, 2010). Ez a megfigyelés a depresszió szinaptogenikus hipotézisével összhangban állhat (Hajszan et al., 2010), miszerint a terhesség alatti stressz az idegsejtek specifikus strukturális változását válthatja ki az anya központi idegrendszerében, hozzájárulva a szülést követő megváltozott kedélyállapothoz (Pawluski et al., 2016). E hipotézis tesztelésére szükségszerű egy olyan vizsgálat, amellyel jobban megértenénk, hogy az idegsejtek plaszticitása milyen mértékben érintheti a stressz okozta anyai hangulatváltozást.

A terhesség utáni időszak egyik mérhető sajátossága a női nemi hormonok ingadozása. A terhesség alatt a $17 \beta$-ösztradiol és a progeszteron szérumkoncentrációja fokozatosan emelkedik, és a menstruációs ciklus szintjének a százszorosát (17ß-ösztradiol), illetve a 
tízszeresét (progeszteron) érik el (Hendrick et al., 1998). Szülés után viszont ez a megemelkedett hormonkoncentráció rövid időn belül drasztikusan lecsökken, és így a szülés utáni időszakot a női nemi hormonok gyakorlatilag hypogonadálisnak minősülő koncentrációja jellemzi (McNeilly, 2001). Korábbi munkánkban megvizsgáltuk, hogy a 17ßösztradiol képes-e segíteni a szervezetnek a stresszel szemben (Hajszan et al., 2010). Az eredményeink azt mutatták, hogy azokban az állatokban nem mutatkozott depresszív magatartás, amelyek részesültek a hormonkezelésben. Figyelembe véve azt a tényt, hogy a női nemi hormonok erősen befolyásolják a szervezet válaszait stresszel szemben (Woolley \& McEwen, 1992; Brunton et al., 2009), fennáll annak a lehetősége, hogy a stressz szinaptolitikus hatását és/vagy a szinapszisok számának összefüggését a depresszív viselkedéssel a nemi hormonok jelentősen megváltoztatják. Így a terhesség és a szülés utáni időszak kihívást jelentett a depresszió szinaptogenikus hipotézisének érvényessége szempontjából.

A női nemi hormonok ingadozása alatt a nők gyakran számolnak be depressziós tünetek megjelenéséről, illetve ezen tünetek felerősödéséről (Bloch et al., 2003; Rubinow \& Schmidt, 2006; Schmidt \& Rubinow, 2009), ami a hormonok kritikus szerepére utalhat a hangulati rendellenességek patomechanizmusában (Galea et al., 2001; Studd \& Panay, 2004; Hajszan et al., 2010). Ezen megállapítások alapján a terhesség utáni depresszió egy hormonmegvont állapottal jár együtt, ami feltételezi, hogy a női nemi hormonok drasztikus csökkenése áll a szülés utáni időszak depressziós tüneteinek hátterében (Parry et al., 2003; Steiner et al., 2003; Douma et al., 2005). Ezt a megállapítást humán vizsgálatokban (Bloch et al., 2000, 2003) és állatmodelleken (Galea et al., 2001; Stoffel \& Craft, 2004; Suda et al., 2008) is igazolták. Érdekes módon több klinikai vizsgálat eredményei is azt sugallták, hogy a hormonális változások csak az arra érzékeny nőknél idéztek elő depressziós tüneteket (Heidrich et al., 1994; Klier et al., 2007).

\section{A posztpartum modell}

A hormonmegvont állapot következményének vizsgálatához Galea és munkatársai elsőként modellezték állatokon a terhesség utáni depresszió hormonális aspektusait. A vizsgálataikban használt patkányokon az ovárium eltávolításával, majd a nemi hormonok megfelelő koncentrációjú pótlásával szimulált terhességi állapotot hoztak létre, majd a 
hormonkezelés megszüntetésével imitálták a szülés utáni időszakot (Galea et al., 2001). A hormonmegvont patkányok ebben a modellben több ideig voltak mozdulatlanok a forced swim viselkedéstani tesztben, mint a kontrollcsoport, amelynek egyedei folyamatosan a kiutat keresték. Ezekben a posztpartum modellezett állatokban a hippokampális neurogenezis csökkent, amit addig valószínüleg az ösztrogén magasabb koncentrációja tartotta fenn (Galea et al., 2001; Stoffel \& Craft, 2004; Green \& Galea, 2008), viszont szorongásos viselkedés, ami kapcsolódik a posztpartum depresszióhoz is, ebben a modellben nem mutatkozott (Stoffel \& Craft, 2004). Ezen modell alapján képesek lehetünk megérteni az egyes hormonok hatását a posztpartum depresszióban tapasztalható viselkedési és plaszticitási változásokra.

Suda és munkatársai továbbgondolták a posztpartum depresszió hormonmegvonásos modelljét (Suda et al., 2008), és a progeszteron hatására helyezték a hangsúlyt. Ez a lépés kritikus lehet egy megfelelő PPD-modell kialakításához, mivel a progeszteron hatással van mind a stresszválaszra, mind az idegsejtek serkenthetőségére (Bitran \& Dowd, 1996; Brunton et al., 2009). Galea és munkatársai modelljében a „terhesség” egésze alatt az állatok ösztrogénkezelést kaptak, míg a progeszteronkezelést csak a „terhesség” 16. napjáig. Ennek eredményeképpen a posztpartum periódus kezdetén csak az ösztrogén került hirtelen megvonásra (Galea et al., 2001). Ez a hormonális változás a rágcsálók terhességére jellemző, ahol a progeszteron szintje a terhesség második fele alatt folyamatosan csökken (Grota \& EikNes, 1967; Pepe \& Rothchild, 1974). Ezzel ellentétben ember esetében mind az ösztrogén, mind a progeszteron szintje folyamatosan növekszik a terhesség folyamán (Hendrick et al., 1998). Az emberre jellemző hormonális változások modellezése érdekében Suda és munkatársai modelljükben az ösztrogénnel együtt a progeszteront is hirtelen megvonták a „terhesség” végén. Ebben a modellben a hormonmegvonási időszak alatt az állatok posztpartum depresszióra jellemző tüneteket produkáltak, úgy, mint a szorongás, az aggresszió és a depresszív viselkedés. 


\section{CÉLKITÜZÉS}

Kutatócsoportunk a közelmúltban kimutatta, hogy a szinaptikus kapcsolatok rendkívül hatékonyan müködhetnek az emberi agykéregben: egy piramissejt egyetlen akciós potenciállal képes lehet egyes interneuronokat nyugalmi membránpotenciáljukról küszöb fölé depolarizálni és akciós potenciálba vinni, míg rágcsálók esetében ugyanezen sejtek csupán küszöb alatti depolarizációt érnek el (Molnár et al., 2008). Disszertációm első fele az agykérgi szinapszisok fajok között megfigyelt különbségét vizsgálja fény- és elektronmikroszkópos technikákkal. A következő kérdésre kerestük a választ:

1. Mi az anatómiai háttere annak, hogy az emberi agykérgi kosársejtekre érkező helyi serkentő bemenetek hatékonysága jelentősen nagyobb, mint a rágcsálók agykérgében?

Csoportunk korábbi tanulmányából az is kiderült, hogy a depresszív viselkedés kialakulásában szerepet játszhat a hippokampális tüskeszinapszisok mennyiségének csökkenése (Hajszan et al., 2009). Felmérésekből arra is fény derült, hogy a nők a szülés utáni időszakban depresszív magatartást mutatnak. Kutatócsoportunk korábbi eredményei azt mutatták, hogy a nemi hormonok megvonásával is enyhe depresszív magatartás következhet be (Hajszan et al., 2010), ezért kíváncsiak voltunk arra, hogy a stressz és a nemi hormonok milyen kapcsolatban állhatnak és hogyan hatnak egy terhességi/posztpartum modellben. A következő kérdésekre kerestük a választ:

2. Milyen viselkedésbeli hatása van a stressznek a terhességi/posztpartum modellállatainkra?

3. Van-e összefüggés a viselkedési tesztben kapott eredmények és a hippokampális tüskeszinapszisszám között ebben a modellben? 


\section{KÖZREMÜKÖDÉSEK}

A disszertációm első feléhez tartozó elektrofiziológiai vizsgálatok tervezését és kivitelezését Molnár Gábor, Rózsa Márton, Nusser Zoltán és Tamás Gábor végezték. Az elektronmikroszkópos vizsgálatok tervezését négyen végeztük, jómagam, Holderith Noémi, Nusser Zoltán és Tamás Gábor. A $20 \mathrm{~nm}$ vastagságú sorozatmetszeteket és rekonstrukcióit jómagam végeztem, az elektronmikroszkópos tomogrammok készítését pedig Holderith Noémi. A vezikulák számolását mind a $20 \mathrm{~nm}$ vastagságról készült sorozatfelvételeken, mind a tomogrammokon Holderith Noémi és jómagam végeztük. A humán mintákat Dr. Barzó Pál biztosította számunkra. A hisztológiai munkákat Tóth Éva végezte, a sejtek háromdimenziós rekonstrukcióit Ábrahám-Tóth Nelli készítette.

A disszertációm második feléhez tartozó magatartás- és ultrastrukturális vizsgálatok tervezését Leranth Csaba, Neil J. Maclusky, Siklós László, Ronald S. Duman és Hajszán Tibor végezte. A magatartásteszt vizsgálatait Huzián Orsolyával, az elektronmikroszkópos vizsgálatokat pedig Csákvári Eszterrel végeztük. A szérum hormonvizsgálatot Dobos Nikoletta végezte. A tüskeszinapszisszám meghatározás, valamint a statisztikai analízis Hajszán Tibor munkája. 


\section{ANYAGOK ÉS MÓDSZEREK}

\section{Kosársejtekre érkezö aszimmetrikus szinapszisok összehasonlító vizsgálata humán és patkány agykéregben}

\section{Agyszeletkészítés}

Minden vizsgálat a Helszinki Nyilatkozat értelmében és a Szegedi Tudományegyetem Etikai Bizottságának engedélyével történt.

A humán agykérgi szeletek olyan kéreg alatti tumorban szenvedő betegek akut biopsziás szöveteiből készültek, akiknél a tumor sebészeti megközelítéséhez szükségszerü volt eltávolítani a frontális, parietális vagy temporális kérgi területek egy részét. A betegek (nők, $\mathrm{n}=15,53 \pm 13$ év; férfiak, $\mathrm{n}=11,43 \pm 24$ év) a mütét előtt a szövetminták ilyen jellegü kutatásra való felhasználását írásban engedélyezték. A műtétek a Szegedi Tudományegyetem Idegsebészeti Klinikáján történtek. Az altatás midazolam $(0,03 \mathrm{mg} / \mathrm{kg})$ és fentanil $(1-2 \mu \mathrm{g} / \mathrm{kg})$ intravénás adásával, valamint intravénás bolusban adott propofollal $(1-2 \mathrm{mg} / \mathrm{kg})$ történt. $\mathrm{Az}$ endotracheális intubáció könnyítésére a páciensek rocuronimot $(0,5 \mathrm{mg} / \mathrm{kg})$ kaptak. Az intubáció 120 másodperccel ezt követően történt és a pácienst $\mathrm{O}_{2}$ és $\mathrm{N}_{2} \mathrm{O} 1$ : 2 arányú elegyével lélegeztették. Az altatás megfelelő szinten tartása szevofluránnal történt. A sebészileg eltávolított szövetblokkokat a mütőben azonnal jéghideg $\left(3-8{ }^{\circ} \mathrm{C}\right)$ magas szacharóz tartalmú mesterséges agy-gerincvelő folyadékba helyeztük $(85 \mathrm{mM} \mathrm{NaCl}, 2,5 \mathrm{mM} \mathrm{KCl}, 1,25$ $\mathrm{mM} \mathrm{NaH}_{2} \mathrm{PO}_{4}, 25 \mathrm{mM} \mathrm{NaHCO}_{3}, 0,5 \mathrm{mM} \mathrm{CaCl}_{2}, 4 \mathrm{mM} \mathrm{MgSO}_{4}, 25 \mathrm{mM}$ d(+)-glükóz, $75 \mathrm{mM}$ szacharóz, 95\% $\mathrm{O}_{2}$-t és $5 \% \mathrm{CO}_{2}$-t tartalmazó gázeleggyel telítve) és a metszés végéig ebben tartottuk.

Patkány agyszeletek készítésénél Wistar törzset használtunk (P 18-28; hím és nőstény egyaránt). Halotán altatás alatt (2-bromo-2chloro-1,1,1-trifluoroetén) dekapitáltuk az állatokat, majd a kipreparált agyszövetüket jéghideg $\left(3-8{ }^{\circ} \mathrm{C}\right)$, magas szacharóz tartalmú, mesterséges agy-gerincvelő folyadékba helyeztük (az összetételét lásd fentebb), és metszés végéig ebben tartottuk. 
A humán vagy a patkány agyszöveteket vibráló pengéjü mikrotómmal (Microm HM 650 V) $350 \mu \mathrm{m}$ vastag szeletekre metszettük. A patkány mintáknál a szeletek koronális síkban készültek az agy szomatoszenzoros részéből. A szeleteket a metszés során használt mesterséges agy-gerincvelő folyadékban hagytuk, amit már $36{ }^{\circ} \mathrm{C}$-ra felfütöttünk. 30 perc inkubáció után ezt a folyadékot fokozatosan lecseréltük alacsony kalciumtartalmú elvezető oldatra $\left(130 \mathrm{mM} \mathrm{NaCl}, 3,5 \mathrm{mM} \mathrm{KCl}, 1 \mathrm{mM} \mathrm{NaH}_{2} \mathrm{PO}_{4}, 24 \mathrm{mM} \mathrm{NaHCO}_{3}, 1 \mathrm{mM} \mathrm{CaCl}, 3 \mathrm{mM}\right.$ $\mathrm{MgSO}_{4}, 10 \mathrm{mM} \mathrm{d}(+)$-glükóz, $95 \% \mathrm{O}_{2}$-t és 5\% $\mathrm{CO}_{2}$-t tartalmazó gázeleggyel telítve). Újabb 30 perc után a hömérsékletet lecsökkentettük $16{ }^{\circ} \mathrm{C}$-ra. A szeleteket további felhasználásukig ebben az oldatban tároltuk.

\section{Elektrofiziológia}

$\mathrm{Az}$ elektrofiziológiai vizsgálatokhoz a szeleteket $36{ }^{\circ} \mathrm{C}$-os elvezető kamrába helyeztük, amelyen keresztül mesterséges agy-gerincvelő folyadékot áramoltattunk 2-3 $\mathrm{ml} /$ perc sebességgel. Az elektrofiziológiai elvezetés során használt mesterséges agygerincvelő folyadék annyiban különbözött a tároláshoz használt oldattól, hogy az $3 \mathrm{mM}$ $\mathrm{CaCl}_{2}$-ot és $1,5 \mathrm{mM} \mathrm{MgSO}_{4}$-ot tartalmazott. Az elektrofiziológiai elvezetéseket whole cell patch clamp technikával végeztük egyszerre legfeljebb kettő II/III. rétegbeli idegsejtből. A sejteket infravörös differenciál interferencia kontraszt (DIC) videomikroszkópia (Zeiss Axioskop FS mikroszkóp, Hamamatsu C2400 CCD kamera, Luigs \& Neumann Infrapatch SM1 manipulátorrendszer, illetve Olympus BX61WI mikroszkóp, PCO CCD kamera, Luigs \& Neumann Infrapatch SM5 manipulátorrendszer) segítségével vizualizáltuk 60-130 $\mu \mathrm{m}$-re a szelet felszínétől 40x vízimmerziós objektívvel. A piramissejtekből történő elvezetéshez háromszög (piramis) alakú sejteket kerestünk, melyek vastag apikális dendritje jól kivehető volt a szeletben. A kosársejtek célzott keresésekor az elöbbiektől különbözö, főként kisebb, kerek, hosszúkás sejteket kerestünk, melyeknél nem volt apikális dendrit jelenlétére utaló jel.

A mikropipettákat (4-6 MOhm) alacsony kloridion tartalmú intracelluláris oldattal töltöttük meg (pH 7,25, 300 mOsm), hogy a GABAerg és glutamáterg események könnyen elkülöníthetőek legyenek. Az elvezetésekhez a következő összetételü intracelluláris oldatot használtuk: $126 \mathrm{mM}$ K-glükonát, $4 \mathrm{mM} \mathrm{KCl,} 4 \mathrm{mM}$ ATP-Mg, 0,3 mM GTP-Na, $10 \mathrm{mM}$ HEPES, $10 \mathrm{mM}$ kreatin-foszfát és $8 \mathrm{mM}$ biocitin. Az elektrofiziológiai elvezetések folyamán a preszinaptikus piramissejtet áramzár üzemmódban, míg a posztszinaptikus interneuront 
feszültségzár üzemmódban tartottuk (HEKA EPC 9/2, HEKA EPC 10 patch-clamp erősítők), a mért elektromos jeleket $8 \mathrm{kHz}$-en szürtük, $50 \mathrm{kHz}$-en digitalizáltuk, és a PatchMaster (HEKA, Lambrech/Pfalz, Németország) szoftver segítségével mértük, majd analizáltuk.

A sejtek passzív elektromos tulajdonságait és tüzelési mintázatukat a bevett gyakorlat szerint a sejtek nyugalmi membrán potenciálján mértük áramzár üzemmódban, 2 másodpercenként 800 ms-os négyszögimpulzust injektálva a sejtbe. A négyszögimpulzusok -100 pA-től kezdődtek és 20 pA-el növekedtek minden egyes ismétléskor. Szinaptikus kapcsolatok vizsgálata során a preszinaptikus sejteket rövid 2-8 ms-os, 600-950 pA-es áraminjekcióval stimuláltuk, hogy akciós potenciált váltsunk ki bennük.

\section{Hisztológia}

A hisztológiai eljárás célja az elektrofiziológiai elvezetések során biocitinnel feltöltött idegsejtek fény- és elektronmikroszkópos vizsgálatokra történő előkészítése volt. Az elektrofiziológiai kísérleteket követően a szeleteket szürőpapírok közé (Millipore) helyeztük a deformáció elkerülése érdekében, majd legalább 12, de legfeljebb 72 órán keresztül fixáltuk 4\% paraformaldehidet, $1,25 \%$ glutáraldehidet és $15 \%$ pikrinsavat tartalmazó $0,1 \mathrm{M}$ foszfátpufferoldatban ( $\mathrm{pH}: 7,4)$. A fixáló oldatot $0,1 \mathrm{M}$ foszfátpufferoldattal történő többszöri átmosással eltávolítottuk a szeletről. A mintákat 10\%, majd 20\% szacharózt tartalmazó $0,1 \mathrm{M}$ foszfátpufferoldattal előkészítettük a fagyasztással történő sejtfeltárásra, amit folyékony nitrogénnel végeztünk. Ezt követően 10\%-os zselatinba ágyazva a mintákat $70 \mu \mathrm{m}$-es metszeteket készítettünk Leica VT 1000S mikrotómmal. A metszeteket ezt követően trispufferoldatban (pH: 7,4) 1 : 100 arányban oldott avidin-biotin-tormaperoxidázkomplexben (ABC, Vector Labs) inkubáltuk $4{ }^{\circ} \mathrm{C}$-on egy éjszakán át. Az enzimreakcióhoz kromogénként 0,05\%-os 3'3-diaminobenzidine (DAB) tetrahidrokloridot, oxidálószerként pedig $0,01 \%$-os $\mathrm{H}_{2} \mathrm{O}_{2}$-ot használtunk. A reakció végeztével a DAB sötétbarna csapadékként csapódott ki a biocitint tartalmazó sejtekben. A metszeteket $0,1 \mathrm{M}$ foszfátpufferoldatban feloldott 1\%-os $\mathrm{OsO}_{4}$-val utófixáltuk, majd desztillált vizes mosás után 1\%-os uranil-acetáttal kontrasztosítást végeztünk. Végezetül a szeleteket gyors felszálló alkoholsorral dehidratáltuk, majd epoxigyantába (Durcupan, Fluka) ágyaztuk tárgylemezre helyezve, amit 48 órán át 56 ${ }^{\circ} \mathrm{C}$-on polimerizáltattunk. 


\section{A sejtek azonosítás és háromdimenziós rekonstrukciója}

A hisztológiai eljárás során láthatóvá tett sejteket jellegzetes morfológiájuk alapján azonosítottuk (Komlósi et al., 2012). Kosársejteknek tekintettük azokat az interneuronokat, amelyek fénymikroszkópos vizsgálat alapján potenciális szinapszist formáltak más sejtek szómájával, illetve periszomatikus régióival. A biocitinnel feltöltött sejtek háromdimenziós rekonstrukcióját a Neurolucida rendszer (MicroBrightField, Colchester, USA) és a BX-60F (Olympus, Tokyo, Japan) fénymikroszkóp segítségével végeztük, 100x olajimmerziós objektívvel. A rekonstrukciók során rekonstruáltuk a sejtek sejttestét, dendritfáját és axonját.

\section{Elektronmikroszkópia}

A fénymikroszkóppal és elektrofiziológiai mérésekkel azonosított kosársejtek ( $\mathrm{n}=3$ humán sejt, három különböző betegből; $n=3$ patkány sejt, három különböző egyedből) dendritszakaszait (human: $150 \mu \mathrm{m}$ távolságban a sejttesttől; patkány: $50 \mu \mathrm{m}$ távolságban a sejttesttől) kivágtuk a metszetükből, és átágyaztuk epoxigyanta blokkokba. A kivágott metszetből ultramikrotómmal (RMC MTXL, Boeckler Instruments, Tucson, Arizona; Ultra $45^{\circ}$, Diatome) $20 \mathrm{~nm}$ vastagságú sorozatmetszeteket készítettünk, melyeket hártyásított (Formvar, TAAB), egylyukú rézgridekre emeltünk. Az ultravékony metszeteket FEI/Philips CM10 elektronmikroszkóppal vizsgáltuk $120 \mathrm{kV}$ feszültségen, 64000x nagyításon, és digitális képeket készítettünk róluk MegaView G2 kamerával. A dendritekről és a preszinaptikus axonterminálisokról háromdimenziós rekonstrukció készült a Reconstruct program segítségével (http://synapses.clm.utexas.edu/).

\section{Elektronmikroszkópos tomográfia}

Az elektronmikroszkópiára átágyazott mintákból $200 \mathrm{~nm}$ vékony metszeteket készítettünk ultramikrotómmal (RMC MTXL, Boeckler Instruments, Tucson, Arizona; Ultra $45^{\circ}$, Diatome), amiket hártyásított (Formvar, TAAB), egylyukú rézgridekre emeltünk. A metszetek pontos vastagságának meghatározására $3: 1$ arányú, kétszeresen desztillált vizes 
oldatban protein A-ra (ProtA) konjugált $10 \mathrm{~nm}$ átmérőjü aranyszemcsékkel jelöltük a gridek mindkét oldalát (Cytodiagnostics - Absource Diagnostics GmbH, Munich, Germany). Kétszeresen desztillált vizes mosás és szárítás után a minták készen álltak a tomográfiára, amit FEI Tecnai G2 Spirit BioTWIN transzmissziós elektronmikroszkóppal 120 kV-on és Eagle 4K HS digitális kamerával, a FEI Xplore3D program segítségével (FEI Europe Nanoport, Eindhoven, The Netherlands) végeztük. $\pm 45^{\circ}$ döntési szögig a digitális felvételek $2^{\circ}$-onként készültek, majd $\pm 45^{\circ}$ és $\pm 65^{\circ}$ között $1^{\circ}$-onként 30000x nagyításon. Az IMODprogramcsomag segítségével készítettük el a tomogrammokat a folyamatosan döntött sorozatképekböl.

\section{Statisztikai analízis}

Eredményeinkben valamennyi értéknek az átlagát és szórását ( $\pm \mathrm{SD}$ ) adtuk meg, feltüntetve a kiértékelésbe belevett minták számát (n) és az eredmények szignifikanciaszintjét. Szignifikánsnak tekintettünk egy eredményt $\mathrm{p}<0,05$ esetén.

\section{A terhesség utáni stressz vizsgálata posztpartum modellen}

\section{A vizsgált állatcsoportok}

Kísérleteinkben közel azonos korú (60-70 posztnatális nap) és tömegü (200-250 g) felnőtt nőstény Sprague-Dawley patkányokat (Charles-River Laboratories, Vác, Magyarország) használtunk. Az állatokat normál körülmények között tartottuk 12 órás fény/sötétség ciklusban, $24{ }^{\circ} \mathrm{C}$-os hőmérsékleten, folyamatosan elérhető ivóvizet és tápot biztosítva. A kísérleteink során az állatok gondozása és laboratóriumi felhasználása a Magyar Egészségügyi Bizottság által elfogadott állatgondozási protokoll (1998) és az Európai Közösségek Tanácsának rendelete alapján (86/609/EEC) történt. 


\begin{tabular}{|c|c|c|c|c|c|}
\hline csoportok & 1. nap & 21. nap & 26. nap & 27. nap & 28. nap \\
\hline \multirow{4}{*}{$\begin{array}{c}\text { Kontroll- } \\
\text { csoport } \\
(\text { Veh, } \mathbf{n}=\mathbf{2 0})\end{array}$} & \multirow{4}{*}{$\begin{array}{c}\text { Ovárium } \\
\text { eltávolítása, } \\
\text { placebo- } \\
\text { kapszula } \\
\text { behelyezése }\end{array}$} & \multirow{4}{*}{$\begin{array}{l}\text { Új placebo- } \\
\text { kapszula } \\
\text { behelyezése }\end{array}$} & & $\begin{array}{l}\text { Nincs stressz } \\
\qquad(\mathrm{n}=3)\end{array}$ & $\begin{array}{l}\text { Szinapszis- } \\
\text { számlálás }\end{array}$ \\
\hline & & & & Stressz $(n=3)$ & $\begin{array}{l}\text { Szinapszis- } \\
\text { számlálás }\end{array}$ \\
\hline & & & & & Active escape teszt \\
\hline & & & & Stressz $(n=14)$ & $\begin{array}{c}\text { Szérumhormonszint } \\
\text { mérés }\end{array}$ \\
\hline \multirow{4}{*}{$\begin{array}{c}\text { Terhesség } \\
\text { utáni csoport } \\
(\mathbf{P p D}, \mathbf{n = 2 0})\end{array}$} & \multirow{4}{*}{$\begin{array}{c}\text { Ovárium } \\
\text { eltávolítása, } \\
\text { hormon- } \\
\text { kapszula } \\
\text { behelyezése }\end{array}$} & \multirow{4}{*}{$\begin{array}{l}\text { Placebo- } \\
\text { kapszulára } \\
\text { váltás }\end{array}$} & & $\begin{array}{l}\text { Nincs stressz } \\
\qquad(\mathrm{n}=3)\end{array}$ & $\begin{array}{l}\text { Szinapszis- } \\
\text { számlálás }\end{array}$ \\
\hline & & & & Stressz $(n=3)$ & $\begin{array}{l}\text { Szinapszis- } \\
\text { számlálás }\end{array}$ \\
\hline & & & & & Active escape teszt \\
\hline & & & & Stressz $(n=14)$ & $\begin{array}{c}\text { Szérumhormonszint } \\
\text { mérés }\end{array}$ \\
\hline \multirow{3}{*}{$\begin{array}{c}\text { Proösztrusz } \\
\text { csoport } \\
\text { (ProE, } n=16)\end{array}$} & \multirow{3}{*}{$\begin{array}{c}\text { Ovárium } \\
\text { eltávolítása, } \\
\text { placebo- } \\
\text { kapszula } \\
\text { behelyezése }\end{array}$} & \multirow{3}{*}{$\begin{array}{l}\text { Új placebo- } \\
\text { kapszula } \\
\text { behelyezése }\end{array}$} & \multirow{3}{*}{$\begin{array}{c}3 \mathrm{mg} / \mathrm{kg} \text { és } \\
4 \mathrm{mg} / \mathrm{kg} \\
\text { ösztradiol- } \\
\text { benzoát } \\
\text { injekció }\end{array}$} & $\begin{array}{l}\text { Ösztrogén- és } \\
\text { progeszteron- } \\
\text { injekció + Nincs } \\
\text { stressz }(n=3)\end{array}$ & $\begin{array}{l}\text { Szinapszis- } \\
\text { számlálás }\end{array}$ \\
\hline & & & & $\begin{array}{c}\text { Ösztrogén- és } \\
\text { progeszteron- } \\
\text { injekció + Stressz } \\
(\mathrm{n}=3)\end{array}$ & $\begin{array}{l}\text { Szinapszis- } \\
\text { számlálás }\end{array}$ \\
\hline & & & & $\begin{array}{c}\text { Ösztrogén- és } \\
\text { progeszteron- } \\
\text { injekció + Stressz } \\
(\mathrm{n}=10)\end{array}$ & $\begin{array}{l}\text { Active escape teszt } \\
\text { Szérumhormonszint } \\
\text { mérés }\end{array}$ \\
\hline \multirow{3}{*}{$\begin{array}{c}\text { Terhesség } \\
\text { utáni kezelt } \\
\text { csoport } \\
\text { (Horm, n=20) }\end{array}$} & \multirow{3}{*}{$\begin{array}{c}\text { Ovárium } \\
\text { eltávolítása, } \\
\text { hormon- } \\
\text { kapszula } \\
\text { behelyezése }\end{array}$} & \multirow{3}{*}{$\begin{array}{l}\text { Új hormon- } \\
\text { kapszula } \\
\text { behelyezése }\end{array}$} & & $\begin{array}{l}\text { Nincs stressz } \\
\quad(\mathrm{n}=3)\end{array}$ & $\begin{array}{l}\text { Szinapszis- } \\
\text { számlálás }\end{array}$ \\
\hline & & & & Stressz $(n=3)$ & $\begin{array}{l}\text { Szinapszis- } \\
\text { számlálás }\end{array}$ \\
\hline & & & & Stressz $(n=14)$ & $\begin{array}{l}\text { Active escape teszt } \\
\text { Szérumhormonszint } \\
\text { mérés }\end{array}$ \\
\hline
\end{tabular}

1. táblázat. Az állatcsoportok és kezelésük 
Minden állatot a kísérlet első napján ovariektomizáltunk. Az ovárium eltávolításával kivédtük a ciklusbeli hormonváltozásokat, amelyek így nem befolyásolták az eredményeinket. Az ovariektómiát altatás alatt végeztük fiziológiás sóoldatban elkevert ketamine alapú altatószerrel (25 $\mathrm{mg} / \mathrm{ml}$ ketamine, $1,2 \mathrm{mg} / \mathrm{ml}$ xylazine, $0,03 \mathrm{mg} / \mathrm{ml}$ acepromazine) izomba injektálva ( $3 \mathrm{ml} / \mathrm{kg}$ dózisban).

Négy csoportot hoztunk létre. Az első csoport az abszolút kontrollcsoport (Veh, $\mathrm{n}=$ 20), amelynek állatai a kísérlet folyamán semmiféle hormonkezelésben nem részesültek, csak hormonmentes placebokapszulát kaptak a börük alá az 1. és a 21. napon. A második csoport a „terhesség utáni”, vagyis a posztpartum csoport $(\mathrm{PpD}, \mathrm{n}=20)$, mely egyedeinek az ovariektomizálás napján ösztrogén és progeszteron tartalmú kapszulát (0,5 mg 17ß-ösztradiol, 50 mg progeszteron, Innovative Research of America, Sarasota, Florida) ültettünk a börük alá, melyből a hormonok a vizsgálat 21 napja során folyamatosan szabadultak fel. A 21. napon a hormonkapszulákat eltávolítottuk, és hormonmentes placebokapszulákat tettünk a helyére. A harmadik csoport a ,proösztrusz” csoport (ProE, $\mathrm{n}=16$ ), amellyel az ösztrusz ciklus proösztrusz fázisára jellemző hormonszintek hatását vizsgáltuk. Ezek az állatok hormonmentes placebokapszulát kaptak a börük alá az 1. és a 21. napon. A 26. napon $3 \mathrm{mg} / \mathrm{kg}$ ösztradiol-benzoátot injektáltunk (szezámolajban feloldva, szubkután) reggel, majd este megismételve $4 \mathrm{mg} / \mathrm{kg}$-ot. A 27. napon 2 órával a stressznek kitevés (vagy stressznek ki nem tevés) előtt ismételten $3 \mathrm{mg} / \mathrm{kg} 17 \beta$-ösztradiolt adagoltunk illetve ezen a napon még $2 \mathrm{mg} / \mathrm{kg}$ progeszteront is bejuttattunk (szezámolajban feloldva, szubkután) a stressznek kitevés (vagy stressznek ki nem tevés) előtt 5 órával. A negyedik csoport a „terhesség utáni kezelt”, vagyis a hormonkezelt csoport (Horm, $n=20$ ), mely egyedeinél szintén beültetésre kerültek a három hétig adagoló hormonkapszulák, amiket a 21. napon ugyanolyan hormontartalmú kapszulákra cseréltünk. A 27. napon csoportonként három állat nem lett stressznek kitéve (NS) a többi állattal szemben, amelyeket elkerülhetetlen stresszkezelésnek (IS) vetettünk alá. A 28. napon a stressznek kitett állatok közül csoportonként három állatot és a stressznek nem kitett állatokat elektronmikroszkópos analízisre használtuk fel. A megmaradt állatokon magatartástesztet (aktív menekülési teszt - AE) végeztünk és szérumhormonszinteket mértünk.

Ezen módszerek menetét és módját a Magatartásvizsgálat részben részletesen kifejtjük. A kísérlet sematikus menetét az 1. táblázatban vázoltuk. 


\section{Magatartásvizsgálat}

Mivel a depressziónak a stressz az egyik legerősebb rizikófaktora (Sousa et al., 2000), a laboratóriumunkban is alkalmazott learned helplessness (LH) platform a major depresszió egyik legmegbízhatóbb állatmodellje (Hajszan et al., 2009). Ebben a modellben a kezdeti elkerülhetetlen stressz (IS) megzavarja az állat tanulási képességét, és ugyanabban a környezetben később már nem lesz képes elmenekülni a már elkerülhető stressz elöl, ami depressziós magatartásnak tekinthető, és az IS-t követően 24 órán belül kialakul (Hajszan et al., 2009). Az LH-kísérletek egy külön erre a célra kialakított ketrecben, az ún. shuttle boxban történnek (Med Associates, St Albans, Vermont, USA) (1. ábra). Ezek a ketrecek patkányokra méretezettek és egy számítógépesen vezérelt guillotine-ajtóval két egyforma részre vannak felosztva. Az IS kivitelezése az állatok talpára adott áramütés formájában történik a ketrec alján lévő fémrácsozaton keresztül. Az első napon az állatok IS kondicionálást kapnak, ami a shuttle boxok egyik felében történik $0,85 \mathrm{~mA}$ áramerősségen. A guillotine-ajtó a kondicionálás teljes időtartama alatt zárva marad. Az IS-kondicionálás 60 áramütésből áll. Egy áramütés átlagosan $15 \mathrm{~s}$ időtartamú váltakozó áramimpulzust és átlagosan $45 \mathrm{~s}$ szünetet jelent. A patkányok „,helpless” viselkedésének súlyosságát az ún. aktív menekülési (active escape - AE) teszttel vizsgáljuk ugyanabban a shuttle boxban, amelyben az IS-t is végrehajtottuk. A menekülési teszt 30 elkerülhető áramütésböl áll, ahol minden egyes áramütés egy maximum $35 \mathrm{~s}$-ig tartó $0,65 \mathrm{~mA}$-os áramimpulzus. Minden egyes áramütés kezdetével egy időben a guillotine-ajtó kinyílik, és az állat a ketrec másik oldalára átszaladva elmenekülhet a stresszhatás elől. Az első 5 próbán az állatoknak a guillotine-ajtón kell átmenniük ahhoz, hogy megszünjön az áram, azonban az ezt követő 25 próbán egy oda-vissza út szükséges. A sikeres meneküléshez szükséges időt mérjük (menekülési latencia) és rögzítjük. Amennyiben az állat $35 \mathrm{~s}$ alatt nem teljesíti a menekülési kritériumot, akkor az hibának minősül (menekülési hiba).

A stressznek ki nem tett állatok is ugyanabban az időben, ugyanannyi időt töltöttek a shuttle boxokban, mint a stressznek kitett állatok, azzal a különbséggel, hogy őket nem érte áramütés (NS). 

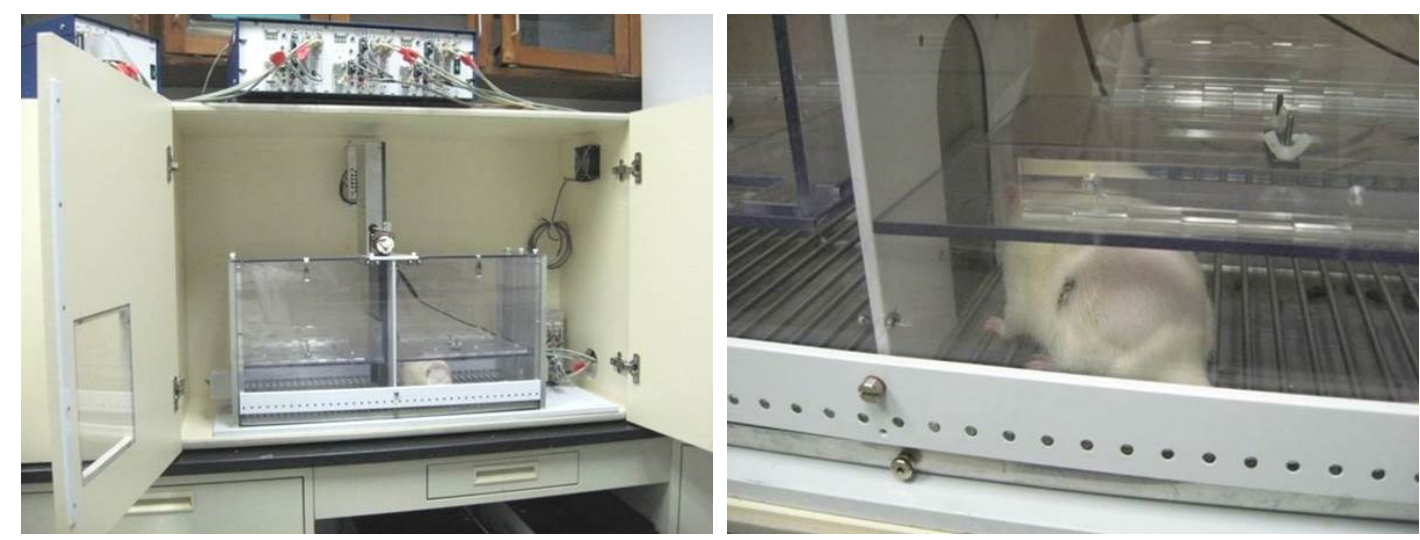

1. ábra. A Med Associates shuttle box rendszer

\section{Hisztológia, elektronmikroszkópia és a tüskeszinapszisok számának meghatározása}

A stresszt követő depresszió bizonyítottan hippokampális szinapszisvesztéssel jár (Hajszan et al., 2009). Ezért a csoportokban lévő állatok egyes hippokampális régióit (CA1sr, CA3sl/sr és DGsm) elektronmikroszkópiával vizsgáltuk meg.

Az állatokat ketamine alapú altatás alatt $(25 \mathrm{mg} / \mathrm{ml}$ ketamine, $1,2 \mathrm{mg} / \mathrm{ml}$ xylazine, $0,03 \mathrm{mg} / \mathrm{ml}$ acepromazine keveréket izomba adagolva $3 \mathrm{ml} / \mathrm{kg}$ dózisban) transzkardiálisan 4\%-os paraformaldehid és $0,1 \%$-os glutáraldehid fixáló oldattal perfundáltuk, majd a kipreparált agyakon 24 órás utófixálást végeztünk $4{ }^{\circ} \mathrm{C}$-on $4 \%$-os paraformaldehiddel. A fixált agyszövetekből kipreparáltuk a hippokampusz régiót. Ezekből $100 \mu \mathrm{m}$-es koronális metszeteket készítettünk. A metszés folyamán a metszeteket 10 csoportba rendeztük, csoportonként kb. $10 \mathrm{db}$ metszettel (az egymást követő metszeteket, egymást követő csoportba helyeztük) és 0.1 M-os foszfátpufferoldatban $(\mathrm{pH} \mathrm{7,4)} \mathrm{tároltuk} \mathrm{beágyazásig.}$ Véletlenszerüen választottunk egy csoportot, melynek metszeteit $0,1 \mathrm{M}$-os foszfátpufferben feloldott $1 \%$-os $\mathrm{OsO}_{4}$-val utófixáltuk. Ezt követően többszörös $0,1 \mathrm{M}$-os foszfátpufferes mosás után a metszeteket felszálló alkoholsorral dehidráltuk, közbeiktatva a 70\%-os etanolban feloldott $1 \%$-os uranil-acetátos kontrasztosítást. Végezetül epoxigyantába (Durcupan, Fluka) tettük a szeleteket, majd tárgylemezen a gyantába ágyazott mintákat 48 órán át $56{ }^{\circ} \mathrm{C}$-on polimerizáltattuk. 
A gyantába ágyazott metszetek a hippokampusz 10 egymástól egyenlő távolságra lévő koronális metszete. A beágyazott metszetekböl kivágtuk a hippokampusz CA1sr, CA3sl/sr és DGsm régióit, majd ezeket gyantablokkokra ragasztottuk. A kivágott metszetekből ultramikrotómmal (Ultracut UCT, Leica) 70 nm-es sorozatmetszeteket készítettünk, melyeket hártyásított (Formvar, TAAB), egylyukú rézgridekre emeltünk. Az ultravékony metszeteket elektronmikroszkóppal (Zeiss CEM 902) vizsgáltuk 11000x nagyításon, majd a szinapszisokról, az egymást követő metszeteken digitális képeket készítettünk. A tüskeszinapszisok számlálását az ún. diszektor módszerrel végeztük (Sterio, 1984). Minden mért régióról 20 diszektor területen (10 pár) számoltunk aszimmetrikus tüskeszinapszisokat állatonként (összesen 60 diszektor terület/állat). A szinapszisokat a posztszinaptikus denzitás és a preszinaptikus aktív zónában a vezikulák együttes jelenlétével azonosítottuk.

\section{Szérumhormonszint-mérés}

Ahhoz, hogy megbizonyosodjunk az állatoknak adagolt nemi hormonok megfelelő vérszintjéröl és a stresszválasz nagyságáról, vérmintákat gyüjtöttünk össze rögtön a menekülési teszt végeztével, ketamine alapú altatószerrel (lásd fentebb) altatott állatokból dekapitálás után. A vérmintákból centrifugálással elválasztottuk a szérumot, amit $-20{ }^{\circ} \mathrm{C}$-on tároltunk a vizsgálatig. A szérumok, 17- $\beta$-ösztradiol, progeszteron és kortikoszteron teljes koncentrációjának a meghatározását enzim immunoassey (EIA) kitek segítségével végeztük. Minden minta esetében két párhuzamos mérést végeztünk.

\section{Statisztikai analízis}

Eredményeinkben valamennyi értéknek az átlagát, szórását (SD - szinapszisszámolás) és átlag standard hibáját (SEM - menekülési teszt és szérumhormon-koncentráció) tüntettük fel, jelezve a kiértékelésbe belevett minták számát (n) és az eredmények szignifikanciaszintjét. Szignifikánsnak tekintettünk egy eredményt $\mathrm{p}<0,05$ esetén. A szinapszisszámolásnál többszempontos varianciaanalízist használtunk (three-way ANOVA), aminél szempont volt a stressz, a hormonkezelés és állaton belüli ismétlődő szempontként a vizsgált agyterület. A varianciaanalízist Tukey-Kramer posthoc teszt követte, hogy összehasonlítsuk a csoportokat. 
A csoportok menekülési tesztjének latenciaeredményeinél és a szérumhormonszintkoncentráció összehasonlításainál egyszempontos varianciaanalízist (one-way ANOVA) és Tukey-Kramer posthoc tesztet használtunk. A csoportok menekülési teszt hibaszámainál nemparametrikus Kruskal-Wallis egyszempontos varianciaanalízist (one-way ANOVA on the ranks) alkalmaztunk Mann-Whitney U-teszttel. 


\section{EREDMÉNYEK}

\section{Kosársejtekre érkezö aszimmetrikus szinapszisok összehasonlító vizsgálata humán és patkány agykéregben}

\section{Azonosított piramissejtek és kosársejtek kapcsoltságának fénymikroszkópos vizsgálata}

Hogy jellemezhessük a humán és a rágcsáló agykérgi kosársejtekre érkező helyi serkentő bemeneteket, whole cell patch clamp technikával végeztünk szimultán elektrofiziológiai elvezetéseket II/III. rétegbeli piramissejt-kosársejt párokból. A sejteket biocitinnel töltöttük fel, hogy láthatókká tehessük a fény- és elektronmikroszkópos technikákhoz. Fénymikroszkóp segítségével háromdimenziós anatómiai rekonstrukciót készítettünk hét humán (2. ábra, B), valamint 15 patkány (3. ábra, B) agykérgi agyszelet preparátumban elvezetett monoszinaptikusan kapcsolt piramis-kosársejt párról. A páros elvezetésekböl kiderült, hogy a humán mintákban mérhető EPSC-k átlagosan nagyobb amplitúdójúak (258,8 $\pm 272,8$ pA; 2. ábra, A), mint a patkány mintákban mérteké $(75,8 \pm$ 58,7 pA; 3. ábra, A) ( $<$ 0,001; MW U-teszt). Annak eldöntésére, hogy a humán mintákban előforduló nagy amplitúdójú EPSC-k összefüggésben állnak-e a szinapszisok számával, fénymikroszkóp segítségével meghatároztuk mindkét fajban a piramissejtek axonjai és a kosársejtek dendritjei között létesített potenciális szinaptikus kapcsolatok számát. A humán piramissejtek átlagosan 3,3 $\pm 1,5$ fénymikroszkóposan azonosított szinapszist létesítettek a velük szinaptikusan kapcsolt kosársejtek dendritjeire (2. ábra, C), ami nem különbözött szignifikánsan a patkány piramissejtek esetében mért értékektöl $(2,9 \pm 1,5$ fénymikroszkóposan azonosított kapcsolat; $\mathrm{p}=0,35$; MW U-teszt) (3. ábra, C). A szinapszisok számának hasonlósága a két fajban arra utal, hogy az elektrofiziológiai mérésekben tapasztalt fajspecifikus különbség a szinapszisokon belül keresendö, ezért a kosársejtekre érkező serkentő bemeneteket elektronmikroszkópos technikákkal tovább vizsgáltuk. 


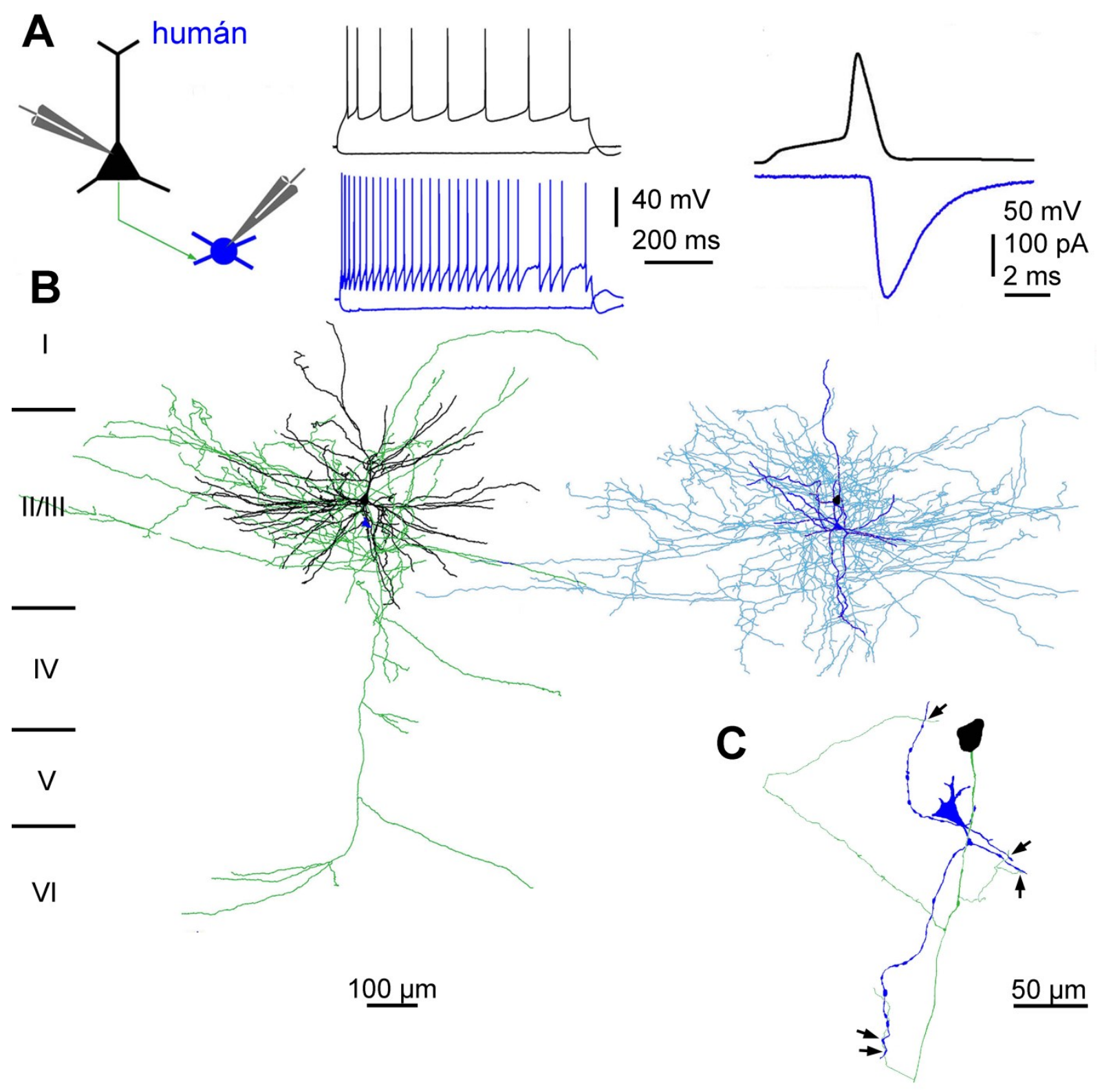

2. ábra. Humán agykérgi piramissejtek és kosársejtek közötti szinaptikus kapcsoltság vizsgálata

$\mathrm{Az}$ A panel bal oldalsó ábráján sematikusan mutatjuk be a szimultán elektrofiziológiai elvezetést egy szinaptikusan kapcsolt piramissejtből (fekete háromszög) és egy kosársejtböl (kék kör). Az A panel középső ábráján egy humán agykérgi piramissejt (fekete), illetve egy humán agykérgi kosársejt (kék) tüzelési mintázatát ábrázoltuk. Az A panel jobb oldalsó ábráján, a piramissejten kiváltott akciós potenciál (fekete) hatására a kosársejten mérhető posztszinaptikus áram (kék) látható. A B panelen egy humán agykérgi piramissejt (szóma, dendrit: fekete; axon: zöld) és egy kosársejt (szóma, dendrit: kék; axon: világoskék) fénymikroszkópos rekonstrukcióját láthatjuk. A sejtek egymáshoz képest fedésben voltak, ezért az egymáshoz viszonyított helyzetüket a másik sejt szómájának feltüntetésével (piramissejt szóma: fekete; kosársejt szóma: kék) ábrázoltuk mindkét rekonstrukción. A C panelen a piramissejt (szóma: fekete; axon: zöld) és a kosársejt (szóma, dendrit: kék) kapcsoltságának fénymikroszkópos azonosítása látható nyilakkal jelölve. 


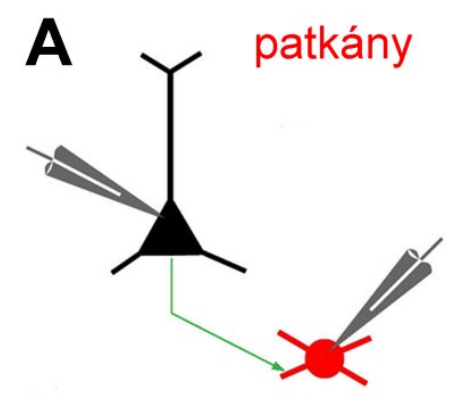

B
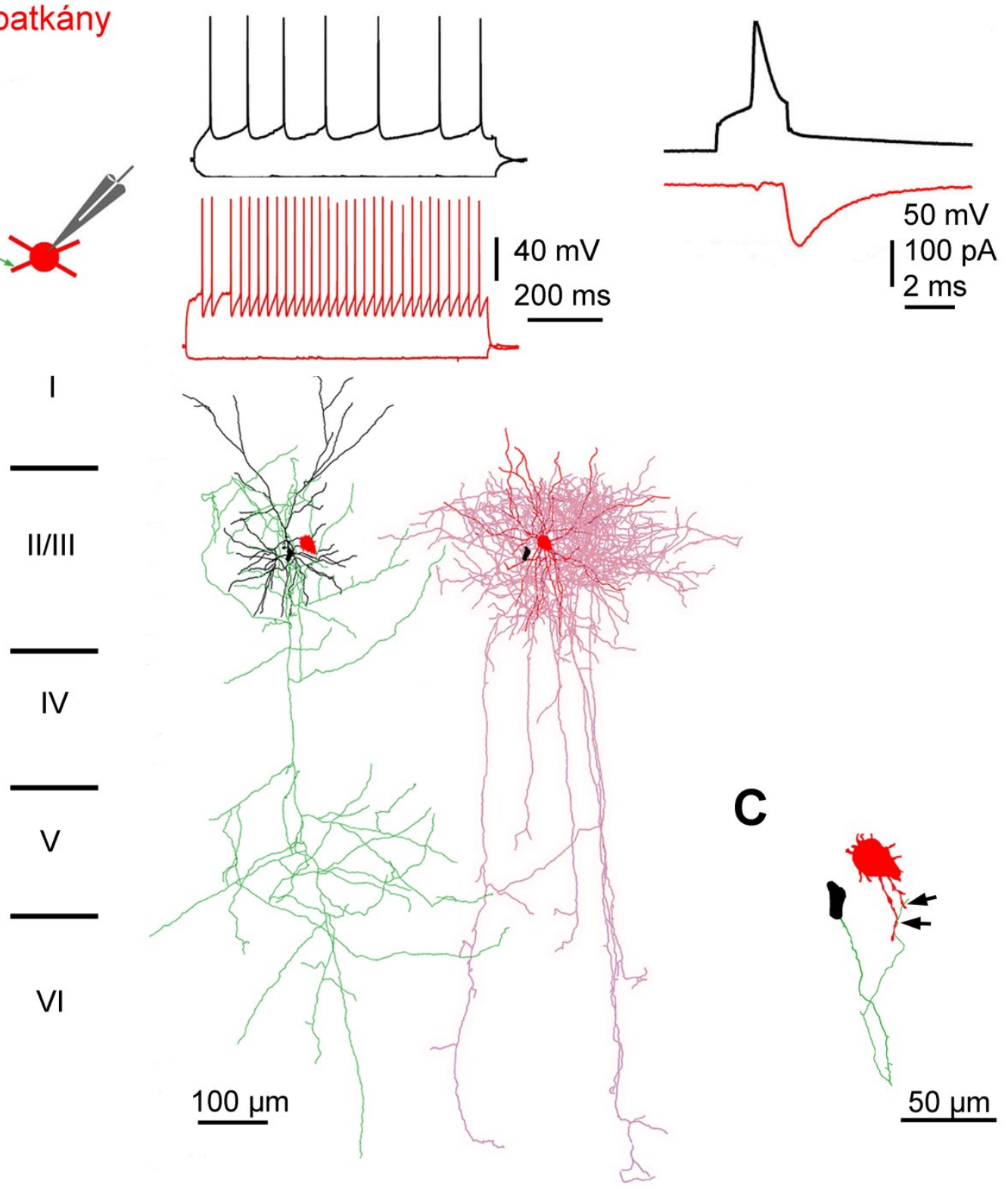

3. ábra. Patkány agykérgi piramissejtek és kosársejtek közötti kapcsoltság vizsgálata

Az A panel bal első ábráján sematikusan mutatjuk be a szimultán elektrofiziológiai elvezetést egy szinaptikusan kapcsolt piramissejtből (fekete háromszög) és egy kosársejtből (piros kör). Az A panel középső ábráján egy patkány agykérgi piramissejt (fekete), illetve egy patkány agykérgi kosársejt (piros) tüzelési mintázatát ábrázoltuk. Az A panel jobb oldalsó ábráján, a piramissejten kiváltott akciós potenciál (fekete) hatására a kosársejten mérhető posztszinaptikus áram (piros) látható. A B panelen egy patkány agykérgi piramissejt (szóma, dendrit: fekete; axon: zöld) és egy kosársejt (szóma, dendrit: piros; axon: rózsaszín) fénymikroszkópos rekonstrukcióját láthatjuk. A sejtek egymáshoz képest fedésben voltak, ezért az egymáshoz viszonyított helyzetüket a másik sejt szómájának feltüntetésével (piramissejt szóma: fekete; kosársejt szóma: piros) ábrázoltuk mindkét rekonstrukción. A C panelen a piramissejt (szóma: fekete; axon: zöld) és a kosársejt (szóma, dendrit: piros) kapcsoltságának fénymikroszkópos azonosítása látható nyilakkal jelölve. 

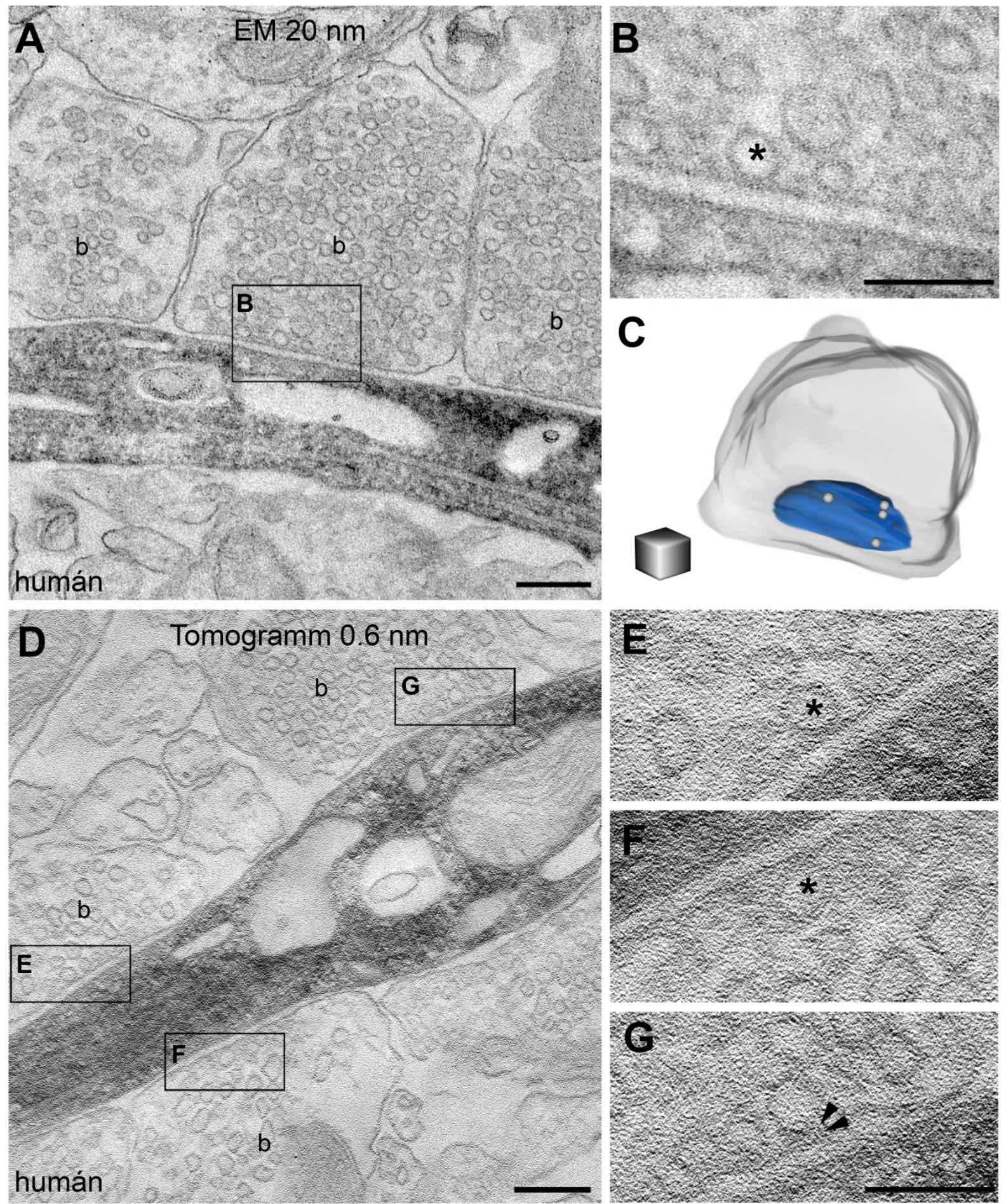

4. ábra. Humán agykérgi kosársejtekre érkezö serkentö bemenetek elektronmikroszkópos vizsgálata

A, B: $20 \mathrm{~nm}$ vastag sorozatmetszetről készült elektronmikroszkópos felvétel egy biocitinnel töltött humán kosársejt dendritjéről (sötét csapadék) és a rá érkező, aszimmetrikus szinapszist formáló serkentő bemenetekről (b: bouton). A B ábra egy közelebbi felvétel az egyik bouton aktív zónájában levő dokkolt vezikuláról (csillag). A C ábrán látható a B ábrán lévő bouton háromdimenziós rekonstrukciója: bouton (szürke), aktív zóna (kék), dokkolt vezikulák (szürke gömbök). D-G: Elektronmikroszkópos-tomográfiás felvétel egy biocitinnel töltött kosársejt dendritjéről (sötét csapadék) és a rá érkezö, aszimmetrikus szinapszist formáló serkentő bemenetekről (b: bouton). Az E, F és $\mathbf{G}$ kép egy közelebbi felvétel a boutonok aktív zónáiról és a bennük lévő dokkolt 
vezikulákról (csillag) vagy egy még nem dokkolt vezikuláról (amelynek a távolsága a membrántól kevesebb, mint 5 nm: nyilak). A lépték mérete az A és $\mathbf{D}$ felvételen $200 \mathrm{~nm}$, a B, E, F és $\mathbf{G}$ képen $100 \mathrm{~nm}$, valamint a $\mathbf{C}$ ábrán a kocka éle $200 \mathrm{~nm}$.

\section{A kosársejtekre érkező serkentő bemenetek elektronmikroszkópos vizsgálata}

Az agykérgi idegsejtek axonterminálisai (bouton) számos vezikulumot tartalmaznak. Ezek közül csak néhány helyezkedik el közvetlenül a preszinaptikus aktív zóna membránjánál, érintkezve azzal (dokkolt vezikulák). Valószínűleg ezek a dokkolt vezikulák azok, amelyek az axonterminálisba érkező akciós potenciál hatására tartalmukat a szinaptikus résbe üríthetik, és így szinaptikus potenciált alakíthatnak ki a posztszinaptikus sejten. A vezikulák gömb alakúak és átlagosan $40 \mathrm{~nm}$ átmérőjüek (Zhang et al., 1998), ezért, hogy a kosársejtekre érkező serkentő bemenetek dokkolt vezikuláinak a pontos számát meghatározhassuk, $20 \mathrm{~nm}$ vastagságú sorozatmetszetek készítésére volt szükségünk. Ezeket a vizsgálatokat három humán és három patkány agykérgi, II/III. rétegbeli kosársejtekre érkező aszimmetrikus szinapszist formáló axonterminálisokon végeztük el (4. és 5. ábra, A-C). A biocitinnel töltött, elektrofiziológiailag azonosított sejtpárok szinaptikus kapcsolatainak a vizsgálatát ellehetetlenítette az axonterminálisokban lévő DAB-csapadék, ezért ezeket a vizsgálatokat biocitinnel töltött kosársejtek dendritszakaszaira érkező jelöletlen aszimmetrikus szinapszisokon végeztük. A két fajban a kosársejtekre érkező azonosított serkentő bemenetek a fénymikroszkópos vizsgálatok alapján humán mintákban átlagosan 149,01 $\pm 137,42 \mu \mathrm{m}$, míg patkány mintákban 47,6 $\pm 25,88 \mu$ m távolságra érkeztek a kosársejtek szómájától. Így az elektronmikroszkópos vizsgálatokat a sejttestektől ilyen távolságokban végeztük.

A $20 \mathrm{~nm}$ vastagságú sorozatmetszetekből készített háromdimenziós rekonstrukciók alapján először a serkentő bemenetek aktív zóna (AZ) területét, majd az egyes aktív zónákra eső dokkolt vezikulák számát határoztuk meg. Az aktív zónák a preszinaptikus axonterminális membránjának azon része, ahol a szinaptikus rés jellegzetesen kiszélesedik. Az eredmények mindkét faj esetén nagy szórást mutattak, azonban elmondható, hogy a humán mintákban mért aktív zónák $\left(\mathrm{n}=22 ; 0,077 \pm 0,051 \mu \mathrm{m}^{2}\right)$ szignifikánsan nagyobbak, mint a patkány mintákban mértek $\left(\mathrm{n}=19 ; 0,041 \pm 0,017 \mu \mathrm{m}^{2}\right)(\mathrm{p}=0,002$; MW U-teszt; 6. ábra, $\mathbf{A})$. 

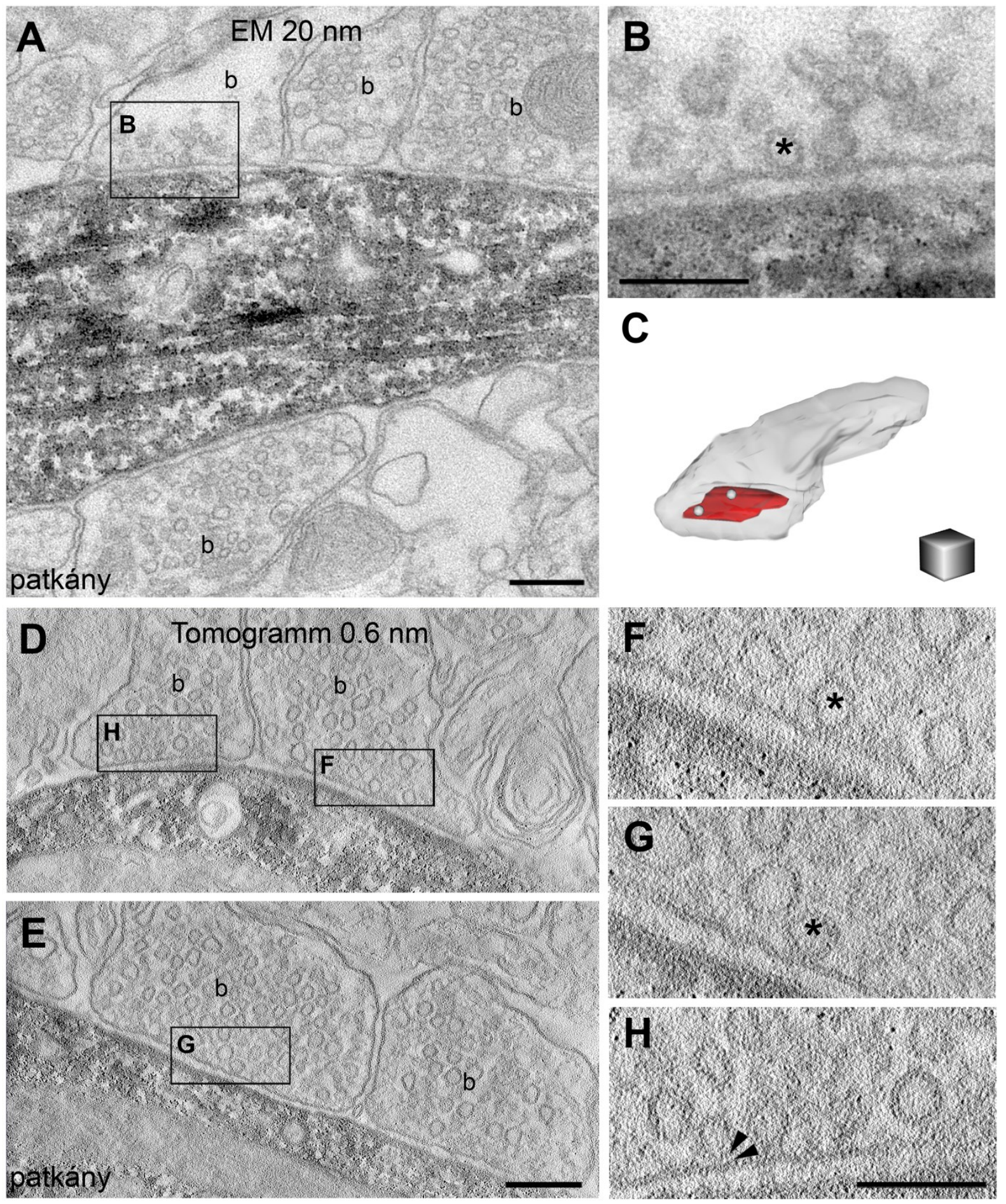

5. ábra. Patkány agykérgi kosársejtekre érkezö serkentö bemenetek elektronmikroszkópos vizsgálata

A, B: $20 \mathrm{~nm}$ vastag sorozatmetszetről készült elektronmikroszkópos felvétel egy biocitinnel töltött patkány kosársejt dendritjéről (sötét csapadék) és a rá érkező, aszimmetrikus szinapszist formáló serkentő bemenetekről (b: bouton). A B ábra egy közelebbi felvétel az egyik bouton aktív zónájában levő dokkolt vezikuláról (csillag). A C ábrán látható a $\mathrm{B}$ ábrán lévő bouton háromdimenziós rekonstrukciója: bouton (szürke), aktív zóna (piros), dokkolt vezikulák (szürke gömbök). D-H: Elektronmikroszkópos-tomográfiás felvétel egy biocitinnel töltött kosársejt dendritjéről (sötét csapadék) és a rá érkező, aszimmetrikus szinapszist formáló serkentő bemenetekről 
(b: bouton). Az E, G és H kép egy közelebbi felvétel a boutonok aktív zónáiról és a bennük lévő dokkolt vezikulákról (csillag) vagy egy még nem dokkolt vezikuláról (amelynek a távolsága a membrántól kevesebb, mint 5 nm: nyilak). A lépték mérete az A, D és $\mathbf{E}$ felvételen 200 nm, a B, F, G és $\mathbf{H}$ képen 100 nm, valamint a $\mathbf{C}$ ábrán a kocka éle $200 \mathrm{~nm}$.

Míg az aktív zóna területek esetében kétszeres különbséget találtunk, addig a dokkolt vezikulák számában négyszeres különbséget állapítottunk meg a két faj összehasonlításánál (p $<0,001$; MW U-teszt; 6. ábra, B). A humán aktív zónákban $(\mathrm{n}=21)$ számlált dokkolt vezikulák mennyisége $4,2 \pm 2,2$, míg a patkány esetében $(n=18)$ ez 1,3 $\pm 0,8$. Az aktív zónák területe és a hozzájuk tartozó dokkolt vezikulák száma között pozitív korrelációt találtunk mindkét faj esetén (Spearman-féle korreláció; rho humán $=0,71$; rho patkány $=0,54 ; \mathbf{6}$. ábra, D). Az aktív zónák mellett a humán mintákban lévő boutonok térfogata is nagyobb volt ( $\mathrm{n}=$ $\left.20 ; 0,14 \pm 0,09 \mu \mathrm{m}^{3}\right)$, mint a patkány mintákban $\left(\mathrm{n}=17 ; 0,05 \pm 0,02 \mu \mathrm{m}^{3}\right)(\mathrm{p}<0,01 ;$ MW Uteszt).

Hogy validáljuk a $20 \mathrm{~nm}$ vastagságú sorozatmetszetek megbízhatóságát, a beágyazott mintáinkból 200 nm vastagságú metszeteket is készítettünk, és azokat elektromikroszkópostomográfiával vizsgáltuk meg. Mivel a vizsgált szinapszisok axiális mérete meghaladja az elektronmikroszkópos-tomográfiával vizsgált metszeteink vastagságát, ezzel az eljárással nem tudtuk meghatározni a szinapszisokban jelen levő dokkolt vezikulák abszolút számát, csak a dokkolt vezikulák sürüségét. Hogy a két elektronmikroszkópos módszert összehasonlítsuk, mindkét eljárással megmértük a dokkolt vezikulák sűrüségét (4. ábra, D-G; 5. ábra, D-H). A $20 \mathrm{~nm}$ vastagságú sorozatmetszeteken mért eredmények azt mutatják, hogy lényeges különbség van a humán $\left(58,5 \pm 24,6 / \mu \mathrm{m}^{2} ; \mathrm{n}=21 \mathrm{AZ}\right)$ és a patkány $\left(32,5 \pm 199 / \mu \mathrm{m}^{2} ; \mathrm{n}=18\right.$ AZ) mintákban ( $\mathrm{p}=0,002$; t-teszt). Ugyanezt a különbséget kaptuk $(\mathrm{p}<0,001$; MW U-teszt) az elektronmikroszkópos-tomográfiára használt mintákból is (humán: 49,5 $\pm 23,8 / \mu \mathrm{m}^{2} ; \mathrm{n}=$ 33 AZ; patkány: $24,3 \pm 16,0 / \mu \mathrm{m}^{2} ; \mathrm{n}=31 \mathrm{AZ}$ ). A két technikából származó eredmények között nincs lényegi különbség (6. ábra, C). 


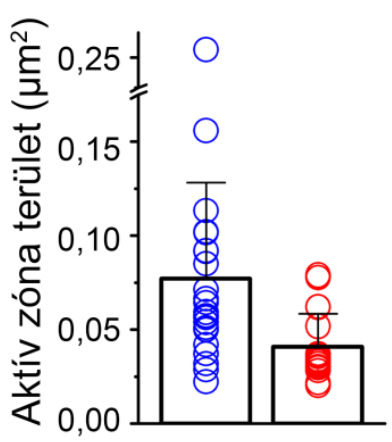

EM $20 \mathrm{~nm}$

EM $20 \mathrm{~nm} \quad$ Tomográfia
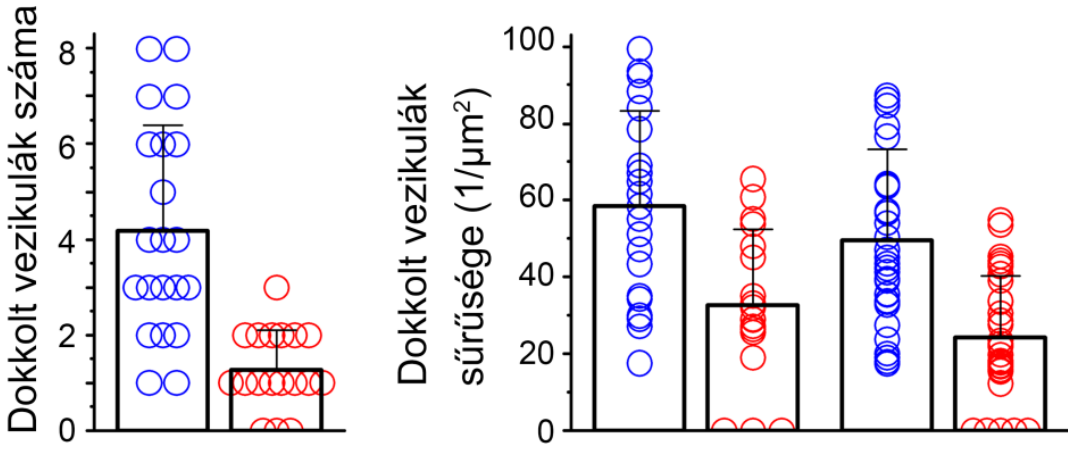

D

EM $20 \mathrm{~nm}$
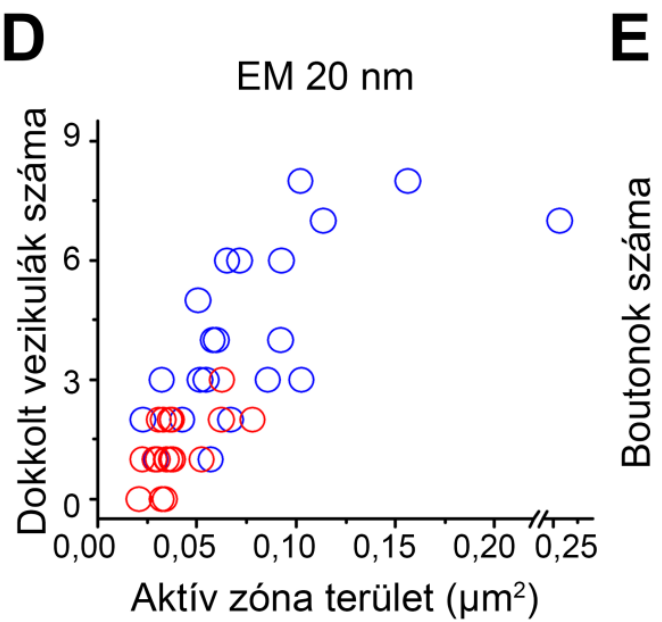

EM $20 \mathrm{~nm}$

humán

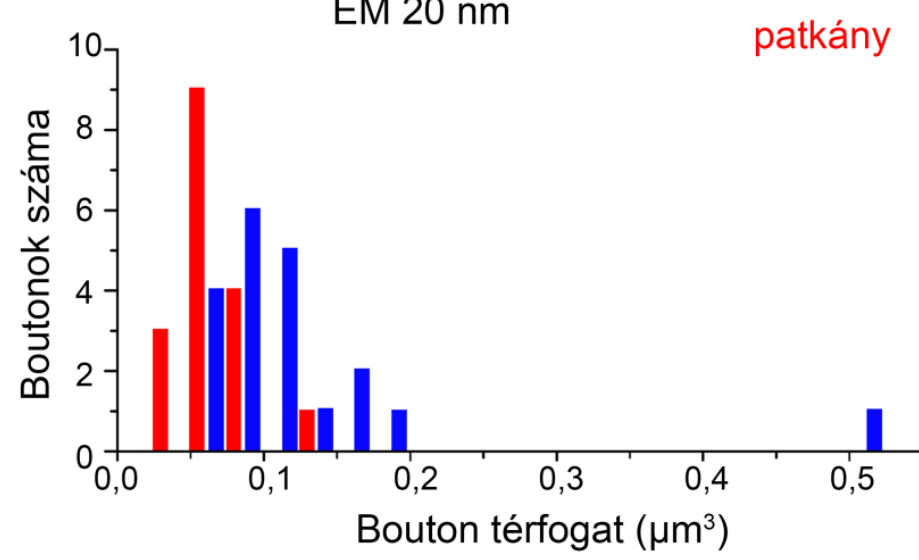

6. ábra. Humán és patkány kosársejtekre érkezö serkentö bemenetek elektronmikroszkópos vizsgálatainak összehasonlitó eredményei

$\mathrm{Az}$ A panelen jól látható, hogy a $20 \mathrm{~nm}$ vastagságú sorozatmetszetekböl összerakott háromdimenziós rekonstrukciókon mért aktív zóna (AZ) területek kétszer nagyobbak a humán mintákban $\left(0,077 \pm 0,051 \mu \mathrm{m}^{2} ; \mathrm{n}=\right.$ $22 \mathrm{AZ} ; 3$ humán minta), mint a patkány mintákban $\left(0,041 \pm 0,017 \mu \mathrm{m}^{2} ; \mathrm{n}=19 \mathrm{AZ} ; 3\right.$ patkány minta) $(\mathrm{p}=0,002$; MW U-teszt). A B panelen a $20 \mathrm{~nm}$ vastagságú sorozatmetszeteken, a teljes aktív zónákban számlált dokkolt vezikulák számát ábrázoltuk. A humán mintákban a dokkolt vezikula mennyiség négyszer több volt $(4,2 \pm 2,2 ; \mathrm{n}$ $=21 \mathrm{AZ})$, mint a patkány mintákban $(1,3 \pm 0,8 ; \mathrm{n}=18 \mathrm{AZ})(\mathrm{p}<0,001$; MW U-teszt $) . \mathrm{A} \mathbf{C}$ panelen összehasonlítottuk a $20 \mathrm{~nm}$ vastagságú sorozatmetszetekből kapott dokkolt vezikula sürüség eredményét (humán: 58,5 $\pm 24,6 / \mu \mathrm{m}^{2} ; \mathrm{n}=21 \mathrm{AZ}$; patkány: 32,5 $\pm 199 / \mu \mathrm{m}^{2} ; \mathrm{n}=18 \mathrm{AZ}$ ) az elektronmikroszkópostomográfiából származó eredményekkel (humán: 49,5 $\pm 23,8 / \mu \mathrm{m}^{2} ; \mathrm{n}=33 \mathrm{AZ}$; patkány: 24,3 $\pm 16,0 / \mu \mathrm{m}^{2} ; \mathrm{n}=$ 31 AZ). A két technikából származó eredmények között nincs különbség. Jól látható, hogy a dokkolt vezikula sürüség szignifikáns különbséget mutat a két faj között (EM $20 \mathrm{~nm}$ : p = 0,002; t-teszt; Tomográfia: $\mathrm{p}<0,001$; MW U-teszt). A D panelen a $20 \mathrm{~nm}$ vastagságú sorozatmetszeteken mért mintáknál pozitív korrelációt látunk a dokkolt vezikula szám és az aktív zóna terület között mindkét fajban (Spearman-féle korreláció; rho humán = 0,71; rho patkány $=0,54)$. Az E hisztogramon a két fajban a $20 \mathrm{~nm}$ vastagságú sorozatmetszeteken mért boutonok térfogatát ábrázoltuk. A humán mintákban a boutonok térfogata nagyobb $\left(0,14 \pm 0,09 \mu \mathrm{m}^{3} ; \mathrm{n}=20\right.$ bouton), mint a patkány mintákban $\left(0,05 \pm 0,02 \mu \mathrm{m}^{3} ; \mathrm{n}=17\right.$ bouton) $(\mathrm{p}<0,01$; MW U-teszt). 


\section{A terhesség utáni stressz vizsgálata posztpartum modellen}

Kísérleteinkben négy csoportot alakítottunk ki, melyek mind ovariektómián estek át. Az első csoport a kontrollcsoportunk, amely eredményéhez viszonyítottuk a többit. Az ebbe a csoportba eső állatok semmilyen hormonpótló kezelésben nem részesültek (Veh csoport). A második csoportnál a hormonkezelést megszakítottuk, hogy a posztpartum időszakot modellezzük (PpD csoport). A harmadik csoport esetében csak a vizsgálat előtt kezeltük az állatokat hormoninjekcióval (ProE csoport), modellezve a proösztrusz fázist, míg a negyedik csoportnál a terhesség állapotát vizsgálva folyamatos hormonkezelésben részesítettük az állatokat (Horm csoport). A csoportok sematikus kísérletmenetét az 1. táblázatban ábrázoltuk.

\section{A stressz és a megváltozott hormonszintek hatása a magatartásra}

Az aktív menekülési teszt összesített eredményeiből a varianciaanalízis alkalmazásával az derült ki, hogy a hormonszintek megváltoztatásának szignifikáns hatása van a menekülési latenciára $\left(\mathrm{F}_{3,48}=6,66 ; \mathrm{p}<0,001\right.$; egyszempontos ANOVA-teszt $)$ és a menekülési hibaszámra $(\mathrm{H}=18,665$; $\mathrm{df}=3$; $\mathrm{p}<0,001$; nem parametrikus Kruskal-Wallis egyszempontos ANOVA-teszt).

Kontrollcsoport (Veh): A kontrollcsoportnál $(\mathrm{n}=14)$ az ovárium eltávolításával megszüntettük a nemi hormonok (ösztrogén és progeszteron) stresszel szemben való befolyását a szervezetre. A nemi hormonok megvonása következtében az elkerülhetetlen stressz (IS) erős berögződést hagyott ezekben az állatokban. A 7. ábra A és $\mathbf{B}$ paneljén látható, hogy a menekülési latencia átlaga a csoportban $22,89 \pm 1,87 \mathrm{~s}$, míg a menekülési hiba $13,04 \pm 2,37$. A menekülési latencia ciklusonkénti lefutását a 8. ábrán tüntettük fel.

Terhesség utáni csoport (PpD): Szülés után az anya szervezetében drámaian lecsökken a nemi hormonok mennyisége. Ezért ennek a jelenségnek a modellezésére ennél a csoportnál $(\mathrm{n}=14)$ a három hétig folyamatosan adagoló hormonkapszulákat a 21. napon placebo-, hormonmentes kapszulára cseréltük. Hasonlóan a kontrollcsoporthoz, a hormonok megvonása és a stressz hatása itt is jól látható, vagyis az elkerülhetetlen stressz jelentős 
teljesítményeséshez vezetett. A menekülési teszt menekülési latencia átlaga a csoportban $22,16 \pm 1,97$ s, míg a menekülési hiba 12,75 \pm 1,99 (7. ábra, A, B). Ez az eredmény a kontrollcsoport eredményétől nem különbözik szignifikánsan sem latenciában $(p=0,989$; TK-teszt), sem hibaszámban ( $\mathrm{p}=0,482$; MW U-teszt). A menekülési latencia ciklusonkénti lefutását a 8. ábrán tüntettük fel, amin szintén jól látható, hogy a $\mathrm{PpD}$ csoport ciklusonkénti latenciában sem tért el a kontrollcsoporttól.

Proösztrusz csoport (ProE): A szervezet az ösztrogén vérszint maximumát a proösztruszban és az ösztrusz reggelén éri el. Ezért ez a csoport $(n=10)$ az elkerülhetetlen stresszt megelőző napon és a stressszhatás napján magas dózisú ösztrogéninjekciót kapott. A 7. ábra A és $\mathbf{B}$ panelén látható, hogy a csoport menekülési teszt eredménye ugyan javult a kontrollcsoportéhoz képest, mégsem szignifikánsan (menekülési latenciában $\mathrm{p}=0,367$; TKteszt; menekülési hibaszámban $\mathrm{p}=0,43$; MW U-teszt). A menekülési latencia átlaga a csoportban $18,71 \pm 1,21 \mathrm{~s}$, míg a menekülési hiba $12,00 \pm 1,16$. A menekülési latencia ciklusonkénti lefutását a $\mathbf{8}$. ábrán tüntettük fel.

Terhesség utáni kezelt csoport (Horm): Terhesség alatt az anya szervezetében megnő a nemi hormonok termelődése. Ez a csoport $(n=14)$ négy héten át tartó, folyamatos magas dózisú ösztrogén- és progeszteronkezelés alatt állt, aminek hatása jól látható a menekülési teszt eredményeiben. A rövidebb menekülési latencia (7. ábra, A; 13,56 $\pm 1,39 \mathrm{~s}$ ) és a kisebb hibaszám (7. ábra, B; $3,71 \pm 0,83$ ) egyértelműen azt mutatja, hogy a női nemi hormonok kivédik a stressz depresszív viselkedést kiváltó hatását. Az eredmények szignifikánsan különböznek a többi csoport eredményeitől mind a menekülési latenciában $(p<0,01$; TKteszt) (7. ábra, A), mind a menekülési hiba számában ( $\mathrm{p}<0,002$; MW U-teszt) (7. ábra, B). Egyedül a proösztrusz csoporttal való összehasonlításnál nem találtunk szignifikáns különbséget a menekülési latenciában ( $\mathrm{p}=0,196$; TK-teszt). A menekülési latencia ciklusonkénti lefutását a 8 . ábrán tüntettük fel. 

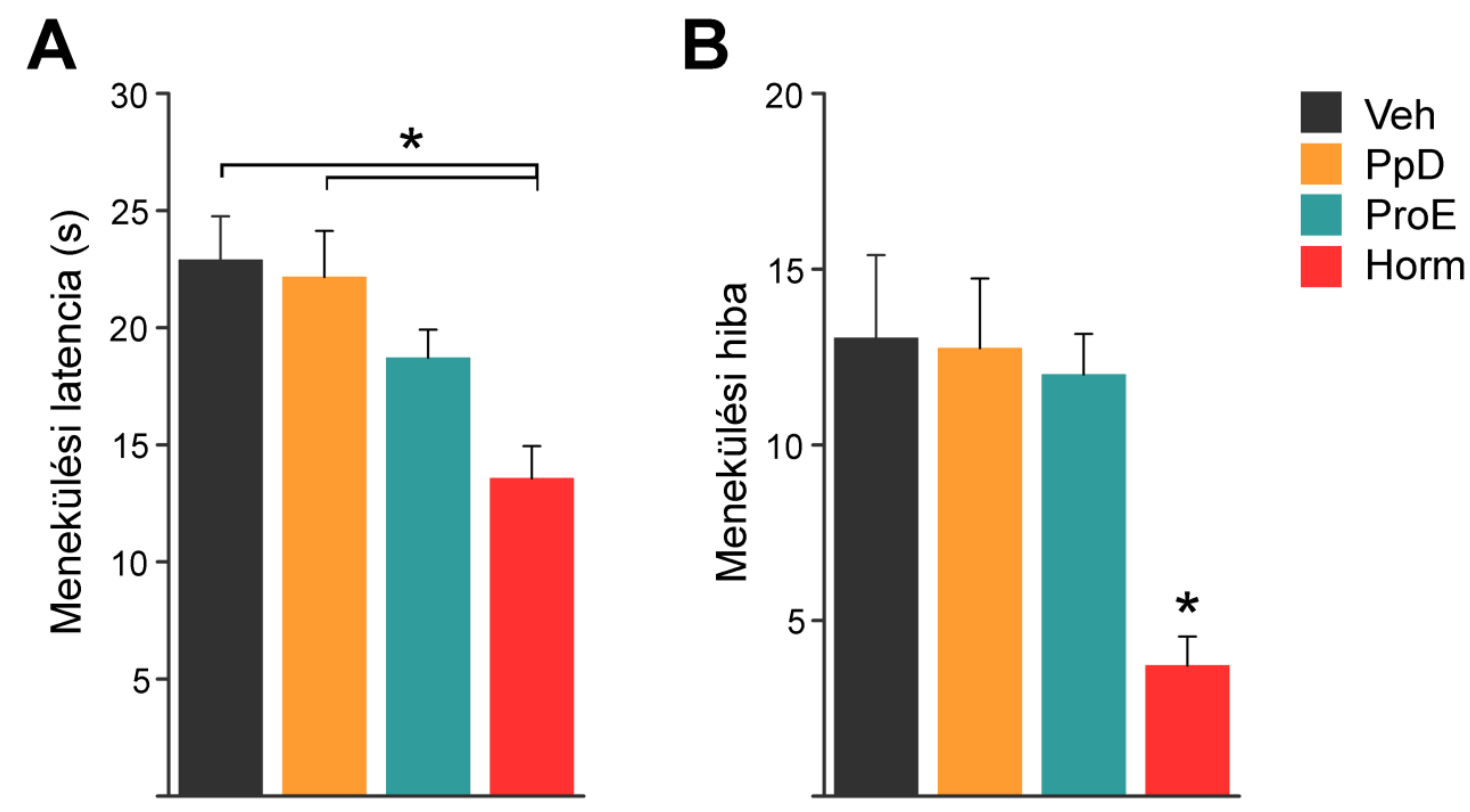

7. ábra. A megváltozott hormonszintek stresszre való hatásának vizsgálata aktív menekülési viselkedési teszttel

Az A panelen a csoportok 30 menekülési ciklusban teljesített átlagidejét ábrázoltuk ( \pm SEM). Jól látható, hogy a pirossal ábrázolt terhesség utáni kezelt csoport (Horm) szignifikánsan jobban teljesített a kontroll- (Veh; szürke) és a terhesség utáni (PpD; sárga) csoport átlagidejénél ( $\mathrm{p}<0,001$, TK-teszt). A B panelen az aktív menekülési tesztben a csoportok menekülési hibaszámának átlagát tüntettük fel ( $\pm \mathrm{SEM})$. A pirossal ábrázolt terhesség utáni kezelt csoport (Horm) szignifikánsan jobban teljesített a kontroll- (Veh; szürke), a terhesség utáni (PpD; sárga) és a proösztrusz (ProE; kék) csoportok átlagidejénél ( $\mathrm{p}<0,002$; MW U-teszt). 


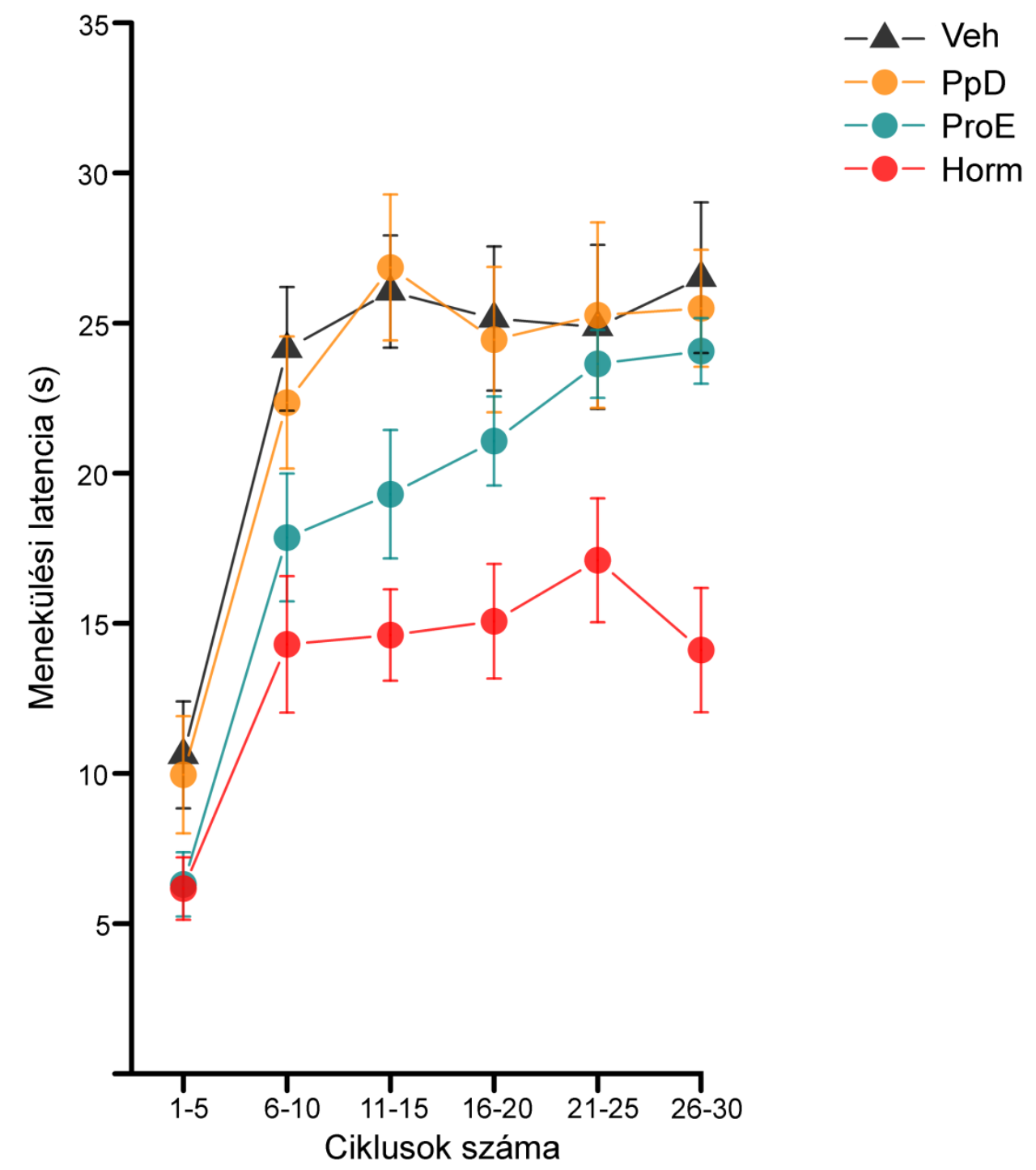

8. ábra. A csoportok menekülési tesztben elért menekülési latenciájának ciklusonkénti lefutása

A diagramon a csoportok átlagos menekülési latenciáját ( $(\mathrm{SEM})$ ábrázoltuk 5-5 ciklus összevonásával (összesen 30 ciklus). Az ábrán jól követhető a menekülési teszt 6. ciklusától induló nehezített feladat megoldásának megnövekedett időigénye. A pirossal ábrázolt terhesség utáni kezelt csoport (Horm) láthatóan gyorsabban teljesítette a ciklusokat, mint a többi csoport. Az is leolvasható, hogy a kontroll- (Veh; szürke) és a terhesség utáni (PpD; sárga) csoportok latenciagörbéje szinte teljesen megegyező. 


\section{A stressz és a megváltozott hormonszintek hatása a hippokampális tüskeszinapszisokra}

A tüskeszinapszisok számának meghatározásánál többszempontos varianciaanalízis alkalmazásával az derült ki, hogy a hippokampális tüskeszinapszisok mennyiségére szignifikáns hatása van az alkalmazott elkerülhetetlen stressznek $\left(\mathrm{F}_{1,16}=635,357 ; \mathrm{p}<0,001\right.$; többszempontos ANOVA-teszt), a hormonkezelésnek $\left(\mathrm{F}_{3,16}=194,998 ; \mathrm{p}<0,001\right.$; többszempontos ANOVA-teszt) és az állaton belüli ismétlődő szempontként vizsgált agyterületeknek $\left(\mathrm{F}_{2,32}=305,073 ; \mathrm{p}<0,001\right.$; többszempontos ANOVA-teszt). Külön-külön összehasonlítva a tüskeszinapszisok számát befolyásoló tényezőket, azt az eredményt kaptuk, hogy a hormonkezelés és a stressz $\left(\mathrm{F}_{3,16}=109,665\right.$; $\mathrm{p}<0,001$; többszempontos ANOVAteszt), a stressz és az agyterületek $\left(F_{2,32}=13,346 ; p<0,001\right.$; többszempontos ANOVA-teszt) valamint az agyterületek és a hormonkezelés $\left(\mathrm{F}_{6,32}=15,978 ; \mathrm{p}<0,001\right.$; többszempontos ANOVA-teszt) között is kapcsolat áll fenn. Tanulmányunk szempontjából a leglényegesebb, hogy a hormonkezelés befolyásolja a stresszre való érzékenységet, ami a hippokampális tüskeszinapszisok számának eltérésével áll összhangban és ezek a hatások agyterületenként különbözhetnek.

Kontrollcsoport (Veh): A stressznek kitett állatoknál (Veh-IS; $\mathrm{n}=3$ ) szignifikánsan kevesebb tüskeszinapszist találtunk, mint a stressznek ki nem tett állatoknál (Veh-NS; $n=3$ ) minden vizsgált hippokampális régióban $(\mathrm{p}<0,04$; TK-teszt; a szinapszisszámok átlaga és szórása a 2. táblázatban látható, illetve a 10. ábra, A paneljén). Ez azt mutatja, hogy az elkerülhetetlen stressz hatására lecsökken a tüskeszinapszisok száma a CA1sr, CA3s1/sr és a DGsm régiókban.

Terhesség utáni csoport (PpD): A stressznek kitett állatok (PpD-IS; $\mathrm{n}=3$ ) CA1sr, CA3sl/sr és a DGsm tüskeszinapszisszáma szignifikánsan kisebb volt a csoportban lévő stressznek ki nem tett állatok $(\mathrm{PpD}-\mathrm{NS} ; \mathrm{n}=3)$ ugyanazon régiói szinapszisai számánál $(\mathrm{p}<$ 0,01; TK-teszt; a szinapszisszámok átlaga és szórása a 2. táblázatban látható, illetve a $\mathbf{1 0}$. ábra B paneljén). Összehasonlítva a Veh-NS állatait a PpD-NS állataival, nem tapasztaltunk szignifikáns különbséget ( $\mathrm{p}>0,2$; TK-teszt), ugyanúgy, mint a Veh-IS állatai és a PpD-IS állatai között sem ( $p>0,25 ;$ TK-teszt). Vagyis a PpD csoportban alkalmazott 
hormonkezelésnek majd hormonmegvonásnak nem volt hatása sem az alap, sem a stressz után mérhető tüskeszinapszis mennyiségre.

Proösztrusz csoport (ProE): A stressznek kitett állatok (ProE-IS; $\mathrm{n}=3$ ) és a stressznek ki nem tett állatok (ProE-NS; $\mathrm{n}=3$ ) tüskeszinapszisszámai a CA1sr, a CA3sl/sr és a DGsm régiókban szignifikánsan különböztek egymástól ( $\mathrm{p}<0,01$; TK-teszt; a szinapszisszámok átlaga és szórása a 2. táblázatban látható, illetve a 10. ábra $\mathbf{C}$ paneljén). Minden vizsgált régióban kevesebb tüskeszinapszist számláltunk a stressznek kitett állatok esetében, mint a stressznek ki nem tett állatoknál. Összehasonlítva a Veh-NS állatokat a ProENS állatokkal, minden vizsgált területen szignifikáns különbséget láthatunk $(\mathrm{p}<0,02$; TKteszt), míg a Veh-IS és a ProE-IS állatok tüskeszinapszisainak száma csak a CA3sl/sr régióban mutatott szignifikáns különbséget $(\mathrm{p}<0,001$; CA1sr régióban $\mathrm{p}=0,054$; DGsm régióban $\mathrm{p}=0,063$; TK-teszt). Mindkét esetben a ProE állatok nagyobb szinapszismennyiséggel rendelkeztek az adott agyterületen.

Terhesség utáni kezelt csoport (Horm): A stressznek kitett (Horm-IS; $\mathrm{n}=3$ ) és a stressznek ki nem tett állatok (Horm-NS; $\mathrm{n}=3$ ) szinapszisszáma a hippokampális régiók közül egyikben sem mutat különbséget ( $p>0,15$; TK-teszt; a szinapszisszámok átlaga és szórása a 2. táblázatban látható, illetve a 10. ábra D paneljén). Ez azt jelenti, hogy a folyamatosan magas szintü női nemi hormonok jelenléte védelmet biztosított a stresszel szemben, ugyanis megakadályozta a tüskeszinapszisok számának csökkenését. Összehasonlítva a Veh-IS és Horm-IS csoportokat, szignifikáns különbség látható a CA3s1/sr és a DGsm régiókban $(\mathrm{p}<0,01 ; \mathrm{TK}$-teszt), míg a CA1sr régióban az eredményeink szerint nincs különbség ( $\mathrm{p}=0,412$; TK-teszt). A Veh-NS és Horm-NS összehasonlításnál a CA3s1/sr és a DGsm régiókban szignifikáns különbséget nem kaptunk ( $\mathrm{p}>0,6$; TK-teszt). A CA1sr régióban különbséget találtunk a két csoportnál, mivel a Horm-NS csoportnál kevesebb szinapszist számláltunk, mint a Veh-NS csoportnál ( $\mathrm{p}<0,02$; TK-teszt). Ez a kevesebb szinapszisszám közel azonos volt a Veh-IS állatainál mért szinapszisszámmal ( $p=0,647$; TKteszt). 


\begin{tabular}{c|cc|cc|ccc|cc|}
$\begin{array}{c}\text { szinapszisszám } \\
\mathbf{x} 10^{9} \\
(\mathbf{a} \text { Veh }\end{array}$ & IS & NS & IS & NS & IS & NS & IS & NS \\
\hline \multirow{2}{*}{ CA1sr } & 1,945 & 3,015 & 1,784 & 2,950 & 2,428 & 4,879 & 2,120 & 2,031 \\
& $\pm 0,167$ & $\pm 0,065$ & $\pm 0,118$ & $\pm 0,239$ & $\pm 0,260$ & $\pm 0,377$ & $\pm 0,277$ & $\pm 0,247$ \\
\hline \multirow{2}{*}{ CA3sil/sr } & 2,363 & 4,879 & 2,382 & 4,938 & 4,374 & 6,947 & 5,011 & $5,048 \pm$ \\
& $\pm 0,253$ & $\pm 0,477$ & $\pm 0,069$ & $\pm 0,207$ & $\pm 0,148$ & $\pm 0,290$ & $\pm 0,619$ & 0,173 \\
\hline \multirow{2}{*}{ DGsm } & 2,252 & 3,015 & 2,061 & 3,288 & 2,745 & 6,590 & 3,280 & 3,106 \\
& $\pm 0,019$ & $\pm 0,249$ & $\pm 0,246$ & $\pm 0,213$ & $\pm 0,227$ & $\pm 0,233$ & $\pm 0,094$ & $\pm 0,147$ \\
\hline
\end{tabular}

2. táblázat. Az adott csoportokon belül, a stressznek kitett (IS) és a stressznek ki nem tett (NS) állatokon számlált teljes hippokampuszra esö tüskeszinapszisok számának átlaga és szórása ( $\pm S D)$

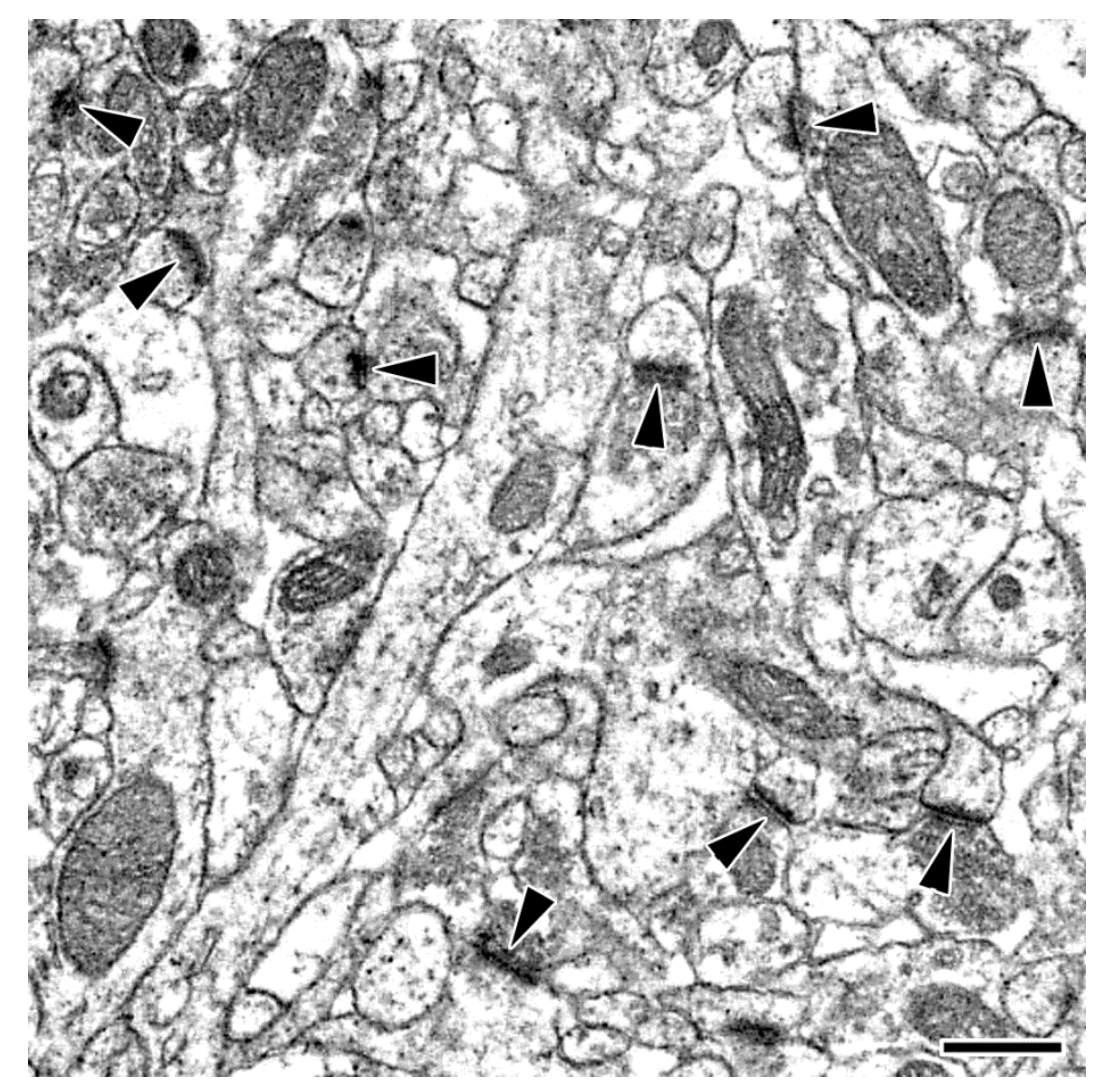

9. ábra. Elektronmikroszkópos felvétel egy stressznek ki nem tett, terhesség utáni csoportba tartozó állat (PpDNS) CA1sr régiójából

A felvételen nyilakkal ábrázoltuk a dendrittüskékre érkező aszimmetrikus szinapszisokat. A lépték mérete 500 $\mathrm{nm}$. 

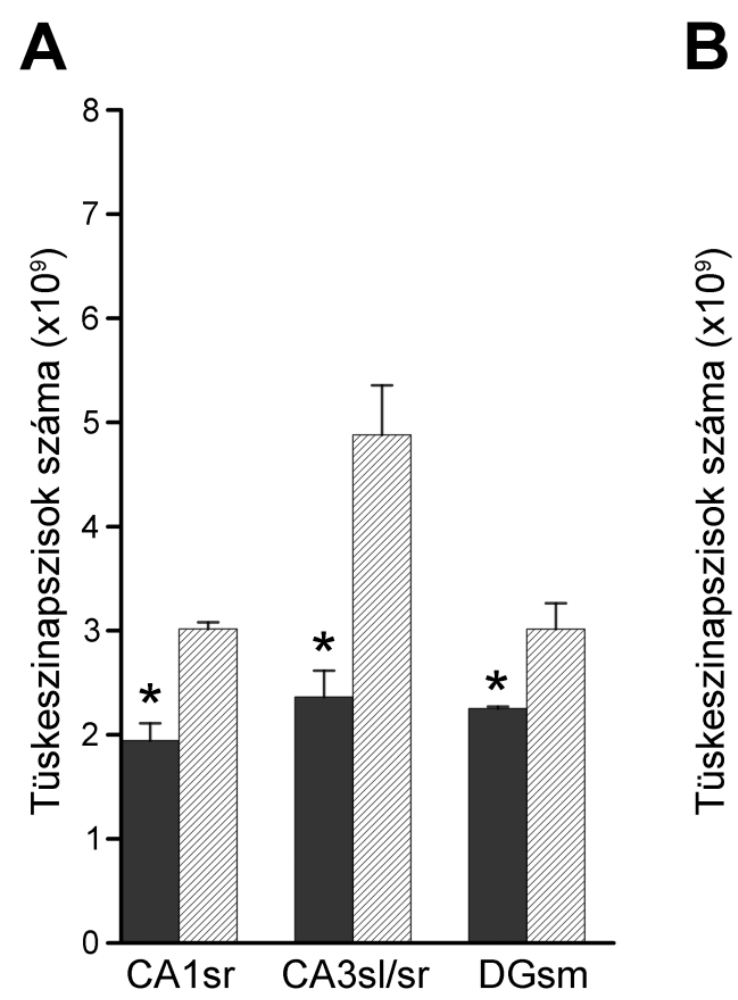

C

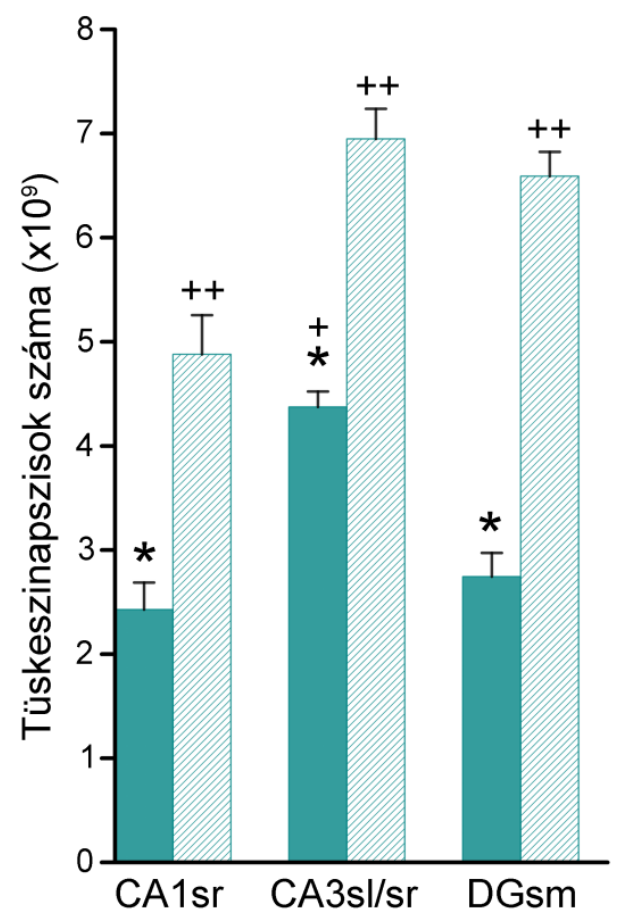

B
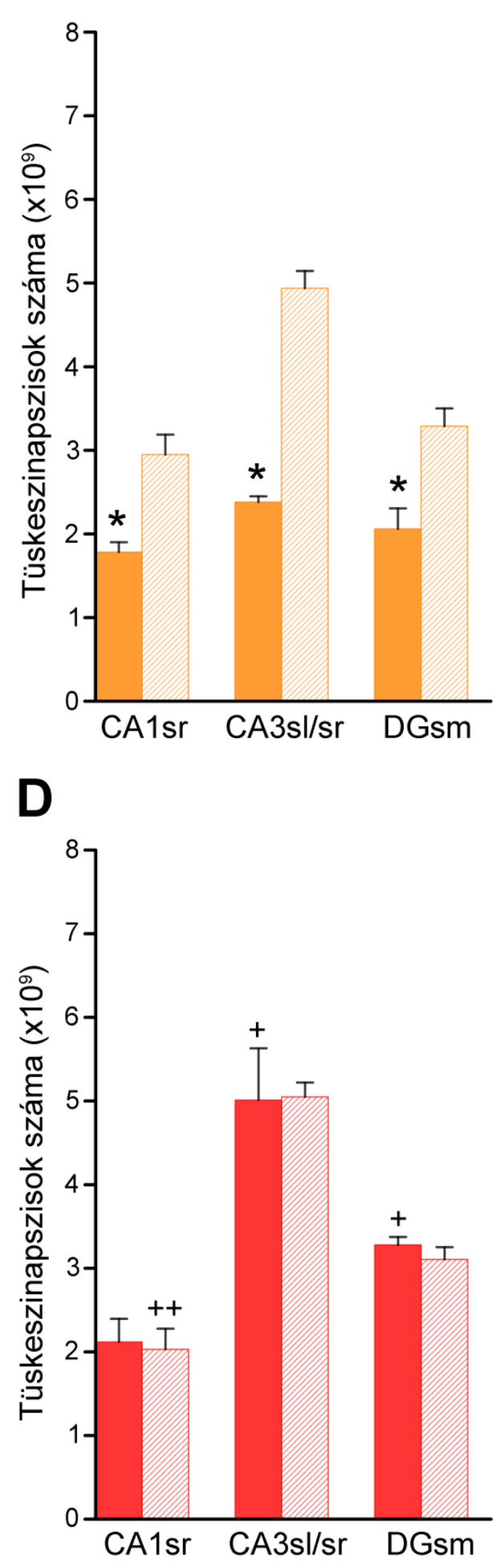

10. ábra. A stressznek kitett (IS) és a stressznek ki nem tett (NS) állatok hippokampális tüskeszinapszisszámainak összehasonlítása

A diagramokon a csoportokban mért tüskékre érkező szinapszisok teljes hippokampuszra eső számának átlagát és szórását ( $\pm \mathrm{SD}$ ) tüntettük fel. Az A panelen jól látható, hogy a kontrollcsoport (Veh) stressznek kitett állatai (teli szürke) szignifikánsan kevesebb tüskeszinapszissal rendelkeztek, mint az ugyanezen csoport stressznek ki nem tett állatai (csíkos szürke) mindhárom mért hippokampális régióban (*p < 0,04; TK-teszt). A B panelen az 
A panelen láthatóakhoz hasonló módon a terhesség utáni csoport $(\mathrm{PpD})$ stressznek kitett állatainál (teli sárga) szignifikánsan kevesebb tüskeszinapszist számláltunk, mint az ugyanezen csoport stressznek ki nem tett állatainál (csíkos sárga), mindhárom mért hippokampális régióban $\left({ }^{*} \mathrm{p}<0,01\right.$; TK-teszt). A $\mathbf{C}$ panelen a proösztrusz csoport (ProE) stressznek kitett (teli kék) és ki nem tett (csíkos kék) állataiban számolt tüskeszinapszisok mennyiségét ábrázoltuk. A két alcsoport közötti különbség itt is jól látható mindhárom mért hippokampális régióban $\left({ }^{*} \mathrm{p}<0,01\right.$; TK-teszt). Azt is megfigyelhetjük, hogy a ProE-NS állatok szinapszisszáma mindhárom mért régióban szignifikánsan magasabb, mint a Veh-NS állatoké (++p $<0,02$; TK-teszt). Különbség látható még a ProE-IS CA3sl/sr régióban kapott szinapszisszámnál, összehasonlítva azt a Veh-IS CA3sl/sr régióban kapott szinapszisszámokkal $(+\mathrm{p}<0,001$; TK-teszt). A D panelen a terhesség utáni kezelt csoport (Horm) stressznek kitett (teli piros) és ki nem tett (csíkos piros) állataiban mért hippokampális tüskeszinapszisok számát ábrázoltuk. Jól látható, hogy a két alcsoport között nem kaptunk szignifikáns különbséget egyik hippokampális területen sem, ezért a CA3sl/sr és DGsm területeken a Horm-IS állatok szinapszisszáma magasabb volt, mint ugyanezen területek Veh-IS szinapszisszáma $(+p<0,01$; TK-teszt). Kevesebb szinapszist számláltunk továbbá a Horm-NS csoport CA1sr régiójában, mint a Veh-NS csoport ugyanezen régiójában $(++\mathrm{p}$ $<0,02$; TK-teszt).

\section{Hormonszintek vizsgálata}

A szérumhormonszint-mérés eredményeiből a varianciaanalízis alkalmazásával az derült ki, hogy a hormonkezelés hatással volt a menekülési teszt utáni kortikoszteron szintekre $\left(F_{3,25}=11,340 ; p<0,001 ;\right.$ egyszempontos ANOVA-teszt $)$.

Kontrollcsoport (Veh): A kontrollcsoport $(\mathrm{n}=8)$ menekülési teszt után vett vérmintáiból kiderült, hogy a kortikoszteron szérumkoncentrációja 345,15 $\pm 36,40$ ng/ml, ami magasnak számít, és erős stresszhatás alkalmával mérhető (Brummelte et al., 2006) (11. ábra). A gonadális szteroidok szérumszintje az alkalmazott mérési módszer érzékenysége alatt volt.

Terhesség utáni csoport $(P p D)$ : A terhesség utáni csoport $(\mathrm{n}=8)$ kortikoszteron szérumkoncentrációja a menekülési teszt után 366,29 $\pm 26,22 \mathrm{ng} / \mathrm{ml}$ volt (11. ábra), ami nem különbözött szignifikánsan a kontrollcsoportban mért kortikoszteron koncentrációtól (p = 0,993; TK-teszt). Az ovariális hormonok szérumszintje az alkalmazott mérési módszer érzékenysége alatt volt. 
Proösztrusz csoport (ProE): A proösztrusz csoportnál $(\mathrm{n}=5)$ a szérum kortikoszteron koncentrációja 259,94 $\pm 25,46 \mathrm{ng} / \mathrm{ml}$, ami nem különbözött szignifikánsan egyik csoport kortikoszteron szintjétöl sem ( $\mathrm{p}>0,05$; TK-teszt) (11. ábra). A 17- $\beta$-ösztradiol szérumkoncentrációja $11,24 \pm 1,12 \mathrm{pg} / \mathrm{ml}$, míg a progeszteron koncentrációja 3,99 $\pm 0,54$ $\mathrm{ng} / \mathrm{ml}$ volt. Ezek a koncentrációk megfelelnek az ösztrusz fázisban mérhető hormonkoncentrációnak (Bridges, 1984), ugyanis a 27. napra időzített proösztrusz szintek a 28. napra lecsökkentek.

Terhesség utáni kezelt csoport (Horm): A terhesség utáni kezelt csoportnál $(\mathrm{n}=8)$ a 17 - $\beta$-ösztradiol szintje $323,13 \pm 76,90 \mathrm{pg} / \mathrm{ml}$, a progeszteron szintje pedig $5,10 \pm 1,53 \mathrm{ng} / \mathrm{ml}$. A kortikoszteron mért koncentrációja azonban 140,21 $\pm 34,51 \mathrm{ng} / \mathrm{ml}$, ami szignifikánsan alacsonyabb, mint a kontroll- vagy a terhesség utáni csoportban mért koncentrációk ( $\mathrm{p}<$ 0,001; TK-teszt) (11. ábra). Ez az érték párhuzamban a menekülési teszt eredményeivel azt mutatja, hogy a folyamatos magas dózisú hormonkezelés megvédte a szervezetet az erős stresszhatás ellen. Összehasonlítva a proösztrusz csoportban mért kortikoszteronszinttel, a két csoport között nem volt szignifikáns különbség ( $p=0,104$; TK-teszt).

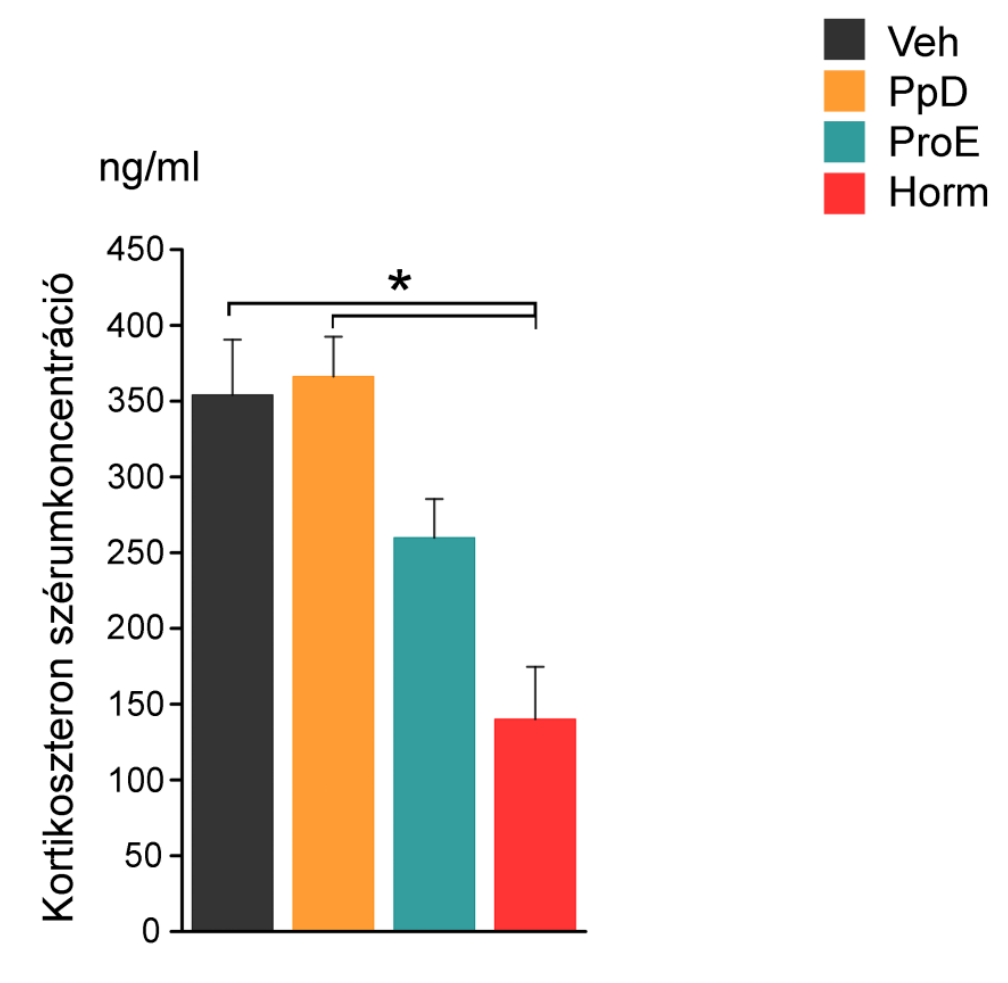

11. ábra. A menekülési teszt végeztével mért kortikoszteron szérumkoncentrációk

A kortikoszteron szérumkoncentrációját ábrázoltuk csoportonként. Jól látható, hogy a terhesség utáni kezelt csoport (Horm; piros) kortikoszteronkoncentrációja szignifikánsan alacsonyabb volt, mint a többi csoportnál ( $\mathrm{p}<$ 0,001 ; TK-teszt). 


\section{MEGBESZÉLÉS}

Doktori munkám folyamán az agykérgi szinapszisok fajok közötti különbségét és a posztpartum depresszióban játszott szerepét kutattuk elektronmikroszkópos- és magatartást vizsgáló technikákkal. Eredményeinkből kiderül, hogy az emberi agykéregben lejátszódó hatékony szinaptikus serkentés hátterében a preszinaptikus terminálisokban található nagyobb számú dokkolt vezikula a felelős, ugyanis mind a vezikulák sűrüsége, mind a preszinaptikus aktív zónák területe az emberi agykéregben kétszerese a rágcsálókénak. Munkánkból az is kiderül, hogy a női nemi hormonok szintjének szülést követő drasztikus csökkenése stresszérzékenységet okozhat, így a szülés utáni stressz csökkent hippokampális tüskeszinapszis-mennyiséget eredményez, ami a terhesség utáni depresszió hátterében állhat.

\section{A humán kosársejtekre érkező helyi serkentő szinaptikus bemeneteket multivezikuláris neurotranszmitter felszabadulás jellemzi}

Az elektronmikroszkópos vizsgálatok kiértékelése alapján elmondhatjuk, hogy fajspecifikus különbséget találtunk a serkentő preszinaptikus bemenetekben. A különbség megmutatkozik mind az aktív zóna méretében, mind a jelátvitelben részt vevő dokkolt vezikulák számában, valamint a boutonok térfogatában. Az aktív zónák átlagos mérete humán mintákban kétszer nagyobb, mint a patkány mintákban mérteké. Továbbá a dokkolt vezikulák sűrüségében is kétszeres különbség látható a két faj között, így összességében szinapszisonként átlagosan négyszer több dokkolt vezikula található egy kosársejtre érkező serkentő boutonban emberben, mint ugyanez patkányban. Az aktív zóna mérete és a hozzájuk tartozó dokkolt vezikulák mennyisége pozitívan korrelálnak egymással mindkét fajban. Továbbá a humán mintákban mért boutonok térfogata is nagyobb (háromszor), mint a patkány mintákban mért serkentő axonterminálisoké.

A kapott eredményekből azt láthatjuk, hogy amíg egy patkány kosársejtre érkező serkentő szinapszisában átlagosan csak egy dokkolt vezikula vesz részt, addig a humán mintákban mért serkentő szinapszisokban a dokkolt vezikulák átlagos száma négy. Ebből a négyszeres különbségből és a hozzájuk tartozó aktív zóna területből meghatározható az egy dokkolt vezikulára eső aktív zóna terület, mely a humán mintákban körülbelül fele akkora 
$\left(0,012 \mu \mathrm{m}^{2}\right)$, mint a patkány mintákban $\left(0,025 \mu \mathrm{m}^{2}\right)$. Tudomásunk szerint a mi munkánk ad először becslést a Katz-féle funkcionális szinaptikus felszabadulási helyek területére az emberi agykéregben (del Castillo \& Katz, 1954) és ad lehetőséget a rágcsálókkal való összehasonlítására. Összehasonlító munkánk érdekes kérdést vet fel: vajon miért igényel kisebb helyet az emberi agyban az egy vezikula felszabadításáért felelős molekuláris gépezet? Ennek a kérdésnek a megválaszolására ezen aktív zónák további ultrastrukturális vizsgálata szükséges. Érdekes lenne megvizsgálni, hogy ez a fajspecifikus különbség érvényes-e minden központi idegrendszeri sejtkapcsolatban, vagy esetleg ez csak az agykérgi mikrohálózatok egyedi jellemzője.

A munkánk azon eredménye, miszerint egy patkány piramissejt aktív zónájához átlagosan egy dokkolt vezikula tartozik, összhangban van a rágcsálókon végzett korábbi eredményekkel (Gulyás et al., 1993; Silver, 2003; Biró et al., 2005), valamint azzal a hipotézissel, miszerint egy aktív zónából egyszerre csak egy vezikula szabadulhat fel (Korn et al., 1982). Ezzel szemben az emberi agykérgi méréseinkből származó adatok szerint ezekre a szinapszisokra multivezikuláris neurotranszmitter felszabadulás jellemzö (Rudolph et al., 2015). Fontos megemlítenünk, hogy eredményeink mindkét faj esetében nagy szórást mutatnak, és az aktív zónák területe pozitívan korrelál a rajtuk található dokkolt vezikulák számával. Így a multivezikuláris neurotranszmitter felszabadítás az agykéregben nem humán specifikus, hanem előfordul a rágcsálók nagyobb területü aktív zónáiban is (Rudolph et al., 2015).

Eredményeink részletes választ adnak arra a kérdésre, hogy milyen mechanizmuson keresztül alakulnak ki az emberi agykéregre jellemző egy sejt aktivitása által kiváltott eseménysorozatok (Molnár et al., 2008; Komlósi et al., 2012; Szegedi et al., 2016), melyek a Hebb-féle neuronhálózatok kialakításában kulcsszerepet játszhatnak. A mechanizmus mozgatórugója a piramissejtek és az egyes posztszinaptikus interneuronok között kialakuló hatékony kapcsolatok, melyek az emberi agykéreg funkcionális felépítésére jellemző csomópontok (hub) kialakításáért és fenntartásáért lehetnek felelősek (Hagmann et al., 2008). A hatékony helyi serkentő kimenetekkel rendelkező piramissejtek ugyanilyen hatékonyak lehetnek a projekciós agykérgi területeiken, ahol képesek lehetnek a tölük távoli inerneuronokon is hasonlóan hatékony küszöb feletti hatást kialakítani. A távoli idegsejteken való hatékony serkentés jellemző az úgynevezett „kis világ” hálózatokra (Park \& Friston, 2013), amely hálózatok felelősek lehetnek a komplex idegrendszeri müködésekért. 
Újonnan kiderült, hogy ezek az általunk vizsgált hatékony serkentő szinapszisok hatékonysága jelentősen lecsökken a preszinaptikus sejt erős aktivitása esetén (Szegedi et al., 2016). Ennek a jelenségnek a hátterében az extracelluláris glutamát megemelkedett koncentrációja áll, amely hasonló módon egyes betegségmodellekben a betegséggel együtt járó szinapszisvesztés okozója (Segal, 1995; Wu et al., 2007). A szinaptikus kapcsolatok pontos müködésének megértése és a fajok közötti különbségek felfedése pontosabb képet ad az idegrendszer és betegségeinek megértéséhez, és hosszútávon segítséget nyújthat ezen betegségek kezelésében is.

\section{A terhesség utáni stressz szinapszisszám-csökkenést és depressziós viselkedést eredményez}

Jelen tanulmányunkban bemutattuk, hogy a pszeudoterhesség utáni időszakban, a hormonmegvont csoport $(\mathrm{PpD})$ állatai hippokampális szinapszisszám-csökkenéssel reagáltak az elkerülhetetlen stresszre. Ez az eredmény megegyezik egy korábbi megfigyelésünkkel, ahol a depresszió kialakulását vizsgáltuk nőstény patkányokon (Hajszan et al., 2010). Ezen korábbi tanulmányunkban a kezeletlen kontrollcsoport teljesített hasonlóképpen a magatartástesztben, mint a jelen tanulmány $\mathrm{PpD}$ csoportja. Ezek az adatok azt a hipotézisünket támasztják alá, miszerint a szülés után bekövetkező stressz a hippokampusz tüskéire érkező szinapszisok számának csökkenésével jár. Azt is bemutattuk kísérleteinkben, hogy a stressz ellen a női nemi hormonok magas szinten tartása védelmet biztosított a hippokampális tüskeszinapszisoknak, vagyis a stressz nem okozott szinapszisszámcsökkenést. Meg kell említenünk, hogy a hippokampális CA1sr régióban a stressznek ki nem tett hormonkezelt csoport (Horm-NS) szinapszisainak száma megegyezett a kontrollcsoport stressznek alávetett állatainak (Veh-IS) szinapszisszámával. Ez az eredmény nem támasztja teljes mértékben alá a női nemi hormonok által közvetített szinapszisvédő hatást. Továbbá, a szérumkortikoszteron-koncentrációk alapján úgy tünik, hogy a szinapszisvédő hatás, legalábbis részben, a stresszválasz mérséklésén keresztül megy végbe. Munkánkban azt is bemutattuk, hogy a nemi hormonok a proösztrusz fázisra jellemző koncentrációban nem képesek kifejteni a stresszel szembeni szinapszisvédelmező hatásukat.

A kísérleteinkben alkalmazott aktív menekülési teszt eredménye szépen korrelál a stresszt követően meghatározott hippokampális tüskeszinapszisok számával. Ebben a 
magatartásvizsgálatban a magasabb menekülési latencia és a több menekülési hiba kevesebb szinapszisszámmal párosult (PpD és Veh csoportokban), a kisebb latencia és kevesebb hibaszám több hippokampális szinapszisszámmal kapcsolódott össze (Horm csoport a Veh csoporthoz viszonyítva), míg egy közepes teljesítmény is a magatartástesztben egy közepes szinapszismennyiséget mutatott (ProE csoport a Veh és a Horm csoporthoz viszonyítva). Ezek az eredmények igazolják azt a hipotézisünket, miszerint a hippokampális szinapszisszámcsökkenés és a depressziós magatartás között kapcsolat áll fenn (Hajszan et al., 2010) és ez a kapcsolat a terhesség utáni stressz esetén is kimutatható.

Tehát elmondható, hogy az általunk felvetett szinaptogenikus hipotézis mindkét sarkalatos pontja igaznak bizonyul a posztpartum modellünkben. Ez a két fontos aspektus a stressz okozta szinapszisszám-csökkenés valamint a szinapszisszám-csökkenés és a depresszív viselkedés közti korreláció.

\section{A stressz hatása az anyai idegrendszerre}

A szülés utáni depresszió egyik fő rizikófaktora a stressz (Lancaster et al., 2010; Davey et al., 2011; Stewart, 2011; Hillerer et al., 2012). Számos, rágcsálókon végzett tanulmány számol be arról, hogy a terhesség alatti tartós stressz a szülést követöen szorongásos viselkedést és a szülöi gondoskodásban való deficitet okoz (Darnaudéry et al., 2004; Smith et al., 2004; O’Mahony et al., 2006; Brummelte \& Galea, 2010; Hillerer et al., 2011). Humán vizsgálatokkal bizonyították, hogy a terhesség alatti időszakban az erős stressz befolyásolja a hippokampális neurogenezist és a CA3 piramissejtek dendritikus morfológiáját (Pawluski et al., 2016), továbbá csökkenti a prefrontális kéregben és a bazális előagyi nucleus accumbens héj régiójában lévő principális sejtek dendrittüskéinek számát és a dendritarborizációjuk sűrüségét (Leuner et al., 2014; Haim et al., 2016), míg növeli a gyrus cinguli kérgi régióban a szinaptofizin szintjét és a bazolaterális amigdalában a dendrittüskék számát (Gemmel et al., 2016; Haim et al., 2016). E változások egy részét antidepresszánskezelésekkel vissza lehetett fordítani (Gemmel et al., 2016; Haim et al., 2016). A terhesség után ért stresszhatás ennél sokkal kevésbé kutatott és ismert. A szervezetben stressz hatására megnövekszik a kortikoszteron koncentrációja (Kant et al., 1987), így indirekt módon már vizsgálták a stressz kimenetelét terhesség után, magas dózisú kortikoszteronnal kezelt állatcsoportokon, ahol csökkent hippokampális neurogenezist (Brummelte et al., 2006) és 
csökkent dendrittüske-sürüséget figyeltek meg (Hillerer et al., 2014). Tehát jelenlegi megállapításunk, miszerint a terhesség után az anya szervezetét érő erős stressz kiválthatja a depresszív viselkedést - valószínüsíthetően a hippokampális tüskeszinapszisok csökkent száma által - hiánypótló ezen kutatási területen.

A hippokampális tüskeszinapszisok számának stressz okozta csökkenése több esemény láncolatának az eredménye, melyek többek között glükokortikoidok és glutamát által mediáltak. Az akut stressz glükokortikoidok által közvetítve nagymértékü hippokampális glutamát felszabadulást okoz (Lowy et al., 1993; Abrahám et al., 1998). A nagymennyiségben felszabaduló glutamát NMDA receptor aktiváción keresztül végbemenő excitotoxikus dendrittüske vesztéshez vezet (Segal, 1995; Wu et al., 2007), amely az általunk tapasztalt hippokampális tüskeszinapszisszám csökkenése mögött állhat. Ezt a mechanizmust támasztja alá kutatócsoportunk korábbi eredménye is, miszerint a magas dózisú kortikoszteron-kezelés az elkerülhetetlen stressz hatását reprodukálva tüskeszinapszisszám vesztéshez és depresszív magatartás kialakulásához vezet (Hajszan et al., 2009).

A fentiekben leírt kutatási eredmények fontos szerepet játszanak a terhesség utáni depresszió kialakulásának megértésében. Sajnálatos módon a terhesség után kialakult depresszióról a jelenlegi ismereteink még nem elégségesek és eltörpülnek a major depresszió kutatásának eredményei mellett (Hajszan et al., 2010; Kang et al., 2012). A terhesség utáni depresszió alatt végbemenő szinaptikus változásokról jelenleg nincsen direkt ultrastrukturális bizonyítékunk, így remélhetőleg a jelenlegi állatmodelles eredményeink segíthetnek megérteni ezt a feltérképezetlen területet.

\section{Az ösztrogén és a progeszteron szerepe}

A Galea és munkatársai által először alkalmazott szimulált terhességi állatmodellben (Galea et al., 2001) a hormonmegvonás kihatással volt a hippokampális neurogenezisre (Green \& Galea, 2008). Ezzel összhangban a jelenlegi kísérleteink is azt mutatják, hogy már egyedül a nemi hormonok megvonása (PpD-NS és Veh-NS csoportok), stresszmentesen is, a proösztrusz szintekhez képest (ProE-NS csoport) csökkentik a hippokampális kapcsolatok számát a terhesség utáni időszakban. Ezt az eredményt más kutatások is alátámasztják, miszerint a petefészek eltávolításával az állatban hippokampális szinapszisszám-csökkenés figyelhető meg, amit az ösztrogén pótlása visszafordít (Woolley \& McEwen, 1992; Leranth et 
al., 2008). A hormonmegvonás viselkedésre gyakorolt hatását önmagában ebben a kísérletsorozatban nem vizsgáltuk, mivel egy előző munkánkban az ovárium eltávolítása után depresszív viselkedést figyeltünk meg, ami hippokampális tüskeszinapszis-vesztéssel párosult (Hajszan et al., 2010).

Eredményeink azt mutatják, hogy a szülés után a nemi hormonok terhességi szinten tartásával (Horm csoport) az elkerülhetetlen stressz okozta károsodás nem jelentkezik. Megfigyelésünket kiegészítik klinikai vizsgálatok is, amelyek igazolják az ösztrogénkezelés előnyeit a terhesség utáni időszakban, amivel a posztpartum depresszió tüneteit sikeresen enyhítették (Sichel et al., 1995; Gregoire et al., 1996; Studd \& Panay, 2004). Az állatmodelleken végzett kísérletek szintén azt mutatták, hogy az ösztrogén csökkenti a depresszív magatartást és potencírozza az antidepresszánsok hatását (Rachman et al., 1998; Frye \& Wawrzycki, 2003; Estrada-Camarena et al., 2004). A terhességi hormonális szintekkel ellentétben, érdekes módon, a nemi hormonok proösztrusz szintje nem tudja kivédeni a terhesség után ért stressz káros hatását. Ez az eredmény összhangban van korábbi kutatásokkal, miszerint az akut stressz csökkenti vagy akár el is törli az ösztrogén és az antidepresszánsok hatását a hippokampális tüskeszinapszisokon (Frick et al., 2004; Hajszan et $a l ., 2010)$. Ez az eltérés a terhességre és a proösztruszra jellemző hormonszintek hatása között valószínüleg a kísérletek közötti különbségekkel magyarázható, mint például az ösztrogén adagolásának hossza és dózisa, vagy az alkalmazott stressz mértéke.

A terhesség utáni időszak alatt a folyamatosan magas koncentrációban jelen levő nemi hormonok (Horm csoport) a szinaptikus és a viselkedésbeli hatásokon túl a szérumkortikoszteron-szintet is alacsonyan tartják a szülés utáni stressz bekövetkezésének ellenére. Ez az eredményünk párhuzamban van több korábbi tanulmánnyal, melyek a női reproduktív rendszer és a stressz közötti összefüggést vizsgálták (Chrousos et al., 1998). Ezekből a tanulmányokból kiderül, hogy a női nemi hormonok hatékonyan képesek leszabályozni a hipotalamusz-hipofízis-mellékvese (HPA)-tengely aktivitását (Douglas et al., 1998; Wartella et al., 2003; Slattery \& Neumann, 2008; Pawluski et al., 2015). A HPAtengely leszabályzásával kialakuló csökkent stresszérzékenység képes lehet a glükokortikoid/glutamát/excitotoxicitás láncreakció mérséklésére, mely folyamat egyébként a hippokampális tüskeszinapszisok számának csökkenéséhez vezetne. Ez a mechanizmus, legalábbis részben, magyarázhatja az általunk tapasztalt szinapszisvédelmező hatást. Érdekes módon a női nemi hormonok stresszválaszt mérséklő hatása nagyon hasonlít egyes régóta alkalmazott antidepresszánsokéra, melyek a kedélyállapot javítását feltételezhetően a stresszre 
való érzékenység megfékezésével érik el (Barden et al., 1995; Nemeroff \& Owens, 2004; Pawluski et al., 2012).

Az eddigi kutatások, amelyek a posztpartum depresszió hormonális aspektusait vizsgálták, föleg az ösztrogénmegvonás hatására helyezték a hangsúlyt (Galea et al., 2001; Stoffel \& Craft, 2004; Green \& Galea, 2008). Ennek eredményeképpen a progeszteron kikerült a kutatások homlokteréből, holott hatékonyan képes befolyásolni a stresszre adott válaszokat és a neuronális aktivitást. A progeszteron egyik metabolitja, az allopregnanolon nevü neuroszteroid, például ópioid dependens módon képes gátolni a terhesség alatti stresszérzékenységet (Brunton et al., 2009). Egyéb progeszteron-származék neuroszteroidok pedig hatékonyan potencíroznak egyes $\mathrm{GABA}_{\mathrm{A}}$ receptorokat (Bitran \& Dowd, 1996; Stell et al., 2003; Oláh et al., 2009), ami az idegsejtek alacsonyabb aktivitásához, és így alacsonyabb glutamát felszabaduláshoz vezet (Stell et al., 2003). Ezen mechanizmusok hibája a stresszre való érzékenységhez, és így posztpartum depresszióhoz vezethet. Ezzel összhangban azok a transzgén egerek, amelyek $\mathrm{GABA}_{\mathrm{A}}$ receptorai képtelenek a neuroszteroid általi potencírozódásra, depressziós magatartást és szorongásos viselkedést mutatnak, továbbá zavar mutatkozik az anyai gondoskodásukban is (Maguire \& Mody, 2008; Mostallino et al., 2009). 


\section{ÖSSZEFOGLALÁS}

Az agykéreg a sejtes szerveződés legkomplexebb struktúrája. Az emberi agykérget $10^{10}$ számú idegsejt és ugyanennyi gliasejt alkotja, ami az egész agy sejtes felépítésének a 90\%-a. Az emberi agykéregben az idegsejtek közötti kapcsolatok száma $10^{12}$ és $10^{14}$ között van, nemtől, kortól és egészségi állapottól függően. Agyunk fő feladata, hogy a külső és belső környezetből érkező, folyamatosan változó és hatalmas mennyiségű információt feldolgozza, tárolja és arra megfelelő választ adjon. Ezen feladatok ellátását az idegsejtek és a köztük lévő szinaptikus kapcsolatok változatossága és plaszticitása teszi lehetővé.

A szinapszison keresztüli jelátvitelt Castillo és Katz tanulmányozta és írta le mint a szinaptikus transzmisszió ma már széles körben elfogadott kvantális modelljét, melynek azóta az anatómiai hátterére is fény derült. A neurotranszmitter a preszinaptikus sejt axonterminálisaiban vezikulumokban raktározódik. A szinaptikus transzmisszió folyamán ezek a vezikulumok szabadítják fel a bennük lévő neurotranszmittert, ami a szinaptikus résbe ürülve a posztszinaptikus sejten fejti ki hatását. A felszabadításra váró vezikulumok a preszinaptikus aktív zónához (AZ) horgonyzódnak (dokkolt vezikulák), és az akciós potenciál hatására exocitózissal ürülhetnek. Ezek a vezikuláris neurotranszmitter-csomagok okozzák a szinaptikus transzmisszió kvantális természetét.

Disszertációm első fele a fajok között megfigyelt agykérgi szinapszisok különbségét vizsgálja fény- és elektronmikroszkópos technikákkal.

Az agykérgi piramissejtek glutamáterg szinapszisaikkal serkentik a helyi gátló sejteket. A legszélesebb körben alkalmazott rágcsáló-modellállatokon már több tanulmány is készült ezen kapcsolatok működéséről. Ezek a szinaptikus kapcsolatok átlagosan 1-4 mV amplitúdójúak, melyek általában egyedül nem képesek a posztszinaptikus interneuronon akciós potenciált kiváltani. Ezzel ellentétben, az emberi agykéregben ugyanezen szinapszisok jóval hatékonyabbak: egy piramissejt egyetlen akciós potenciálja képes lehet a környező gyorsan tüzelö interneuronokat nyugalmi membránpotenciáljukról küszöb fölé depolarizálni és akciós potenciálba vinni. A hatékony serkentés hatására poliszinaptikus hálózatok aktiválódnak, amelyek a Hebb-féle hálózatok alapjául szolgálhatnak.

Az elektronmikroszkópos vizsgálataink kiértékelése alapján fajspecifikus különbséget találtunk a gyorsan tüzelő kosársejtekre érkező serkentő bemenetekben. A különbség megmutatkozik mind az aktív zóna méretében, mind a jelátvitelben részt vevő dokkolt 
vezikulák számában, valamint a boutonok térfogatában. Az aktív zónák átlagos mérete humán mintákban kétszer nagyobb, mint a patkány mintákban mérteké. Továbbá a dokkolt vezikulák sürüségében is kétszeres különbség látható a két faj között, így összességében szinapszisonként átlagosan négyszer több dokkolt vezikula található egy kosársejtre érkező serkentő boutonban emberben, mint patkányban. Az aktív zóna mérete és a hozzájuk tartozó dokkolt vezikulák mennyisége pozitívan korrelálnak egymással mindkét fajban. Továbbá a humán mintákban mért boutonok térfagata is nagyobb (háromszor), mint a patkány mintákban mért serkentő axonterminálisoké.

A kapott eredményekből azt láthatjuk, hogy amíg egy patkány kosársejtre érkező serkentő szinapszisában átlagosan csak egy dokkolt vezikula vesz részt, addig a humán mintákban mért serkentő szinapszisokban a dokkolt vezikulák átlagos száma négy. Ebből a négyszeres különbségből és a hozzájuk tartozó aktív zóna területböl meghatározható az egy dokkolt vezikulára eső aktív zóna terület, mely a humán mintákban körülbelül fele akkora $\left(0,012 \mu \mathrm{m}^{2}\right)$, mint a patkány mintákban $\left(0,025 \mu \mathrm{m}^{2}\right)$. Tudomásunk szerint a mi munkánk ad először becslést a Katz-féle funkcionális szinaptikus felszabadulási helyek területére az emberi agykéregben és ad lehetőséget a rágcsálókkal való összehasonlítására.

Disszertációm második felében a terhesség utáni depresszió anatómiai hátterét vizsgáltuk.

A major depresszió patomechanizmusának egyik fö komponense a hippokampusz müködésének rendellenessége. A rendellenes müködéssel együtt jár a hippokampusz térfogatának csökkenése, a hippokampális neurogenezis hanyatlása és a triszinaptikus kört alkotó tüskeszinapszisok számának csökkenése, amelyek hatékony antidepresszánskezelésekkel visszafordíthatóak vagy megakadályozhatóak. Habár a legutóbbi kutatási eredmények beszámolnak a hippokampusz anyai stressz indukálta strukturális változásairól, közvetlen elektronmikroszkópos eredmény a hippokampusz szinaptikus változásairól posztpartum depresszióban jelenleg nincs.

Korábbi kutatások alapján a női nemi hormonok megvonása stresszre való érzékenységet eredményezett a szülés utáni időszakban. Már a petefészek eltávolításával bizonyos fokú magatartás következik be, amit az elkerülhetetlen stressz felerősít. Ezzel a megfigyeléssel összhangban a jelenlegi kutatásunk bemutatja, hogy a szülést követő stressz a hormonmegvont pszeudoterhességi állatmodellünkön is hasonló kárt okozott, azaz a hippokampusz triszinaptikus szerveződésének minden szintjén az aszimmetrikus szinaptikus kapcsolatok számának csökkenéséhez vezetett, amely az információáramlás és így a 
hippokampusz diszfunkcióját eredményezheti. A stressz hatással van számos agyterületre, azonban a depresszív viselkedés kialakulásában ezek közül a hippokampusz játszhat kulcsszerepet, mivel az részt vesz a tanulás és memória folyamatokban, a stresszválasz visszacsatolásában és a motivációért felelős agyterületek modulációjában. Tehát a hippokampális diszfunkció hozzájárulhat a kognitív képesség hanyatlásához és a motivációvesztéshez, amik a terhesség utáni depresszió és a major depresszió gyakori tünetei.

Jelen tanulmányunk azt is megmutatta, hogy a női nemi hormonok magas koncentrációja (ami a terhesség alatt mérhető) védelmet biztosít a stressz ellen a hippokampális tüskeszinapszisoknak. Fontos megemlítenünk, hogy ez a szinapszis-védelmező hatás együtt jár a menekülési teljesítmény javulásával a menekülési tesztben, vagyis a csökkent depressziós magatartással. Ezek az eredmények is alátámasztják a major depressziónál felállított hipotézisünket, miszerint a szinapszisvesztés hozzájárul a depresszív tünetek kialakulásához, így a szinapszisok védelme elméletileg kedvező terápiás hatással járhat. 


\section{SUMMARY}

The cerebral cortex is one of the most complex cellular structures. The human cerebral cortex consists of $10^{10}$ neurons and the same number of glial cells, which accounts for $90 \%$ of all the cellular elements. The number of synaptic junctions connecting neurons ranges from $10^{12}$ to $10^{14}$ depending on gender, age, and health. The main task of our brains is to process, store and respond to an ever-changing and vast amount of information from external and internal environments. These tasks are put into effect by the variety and plasticity of the neurons and their synaptic connections.

The widely accepted quantal model of the synaptic transmission was formulated by Castillo and Katz and since then the anatomical backround of the synaptic transmission has became clear. The neurotransmitter is stored in vesicles of the axon terminals of the presynaptic cell. During synaptic transmission, these vesicles release their neurotransmitter content into the synaptic cleft, exerting its effect upon the postsynaptic cell. The vesicles anchored to the presynaptic active zone (docked vesicles) are waiting to be released by a presynaptic action potential arriving to the axon terminal. The the quantum nature of synaptic transmission are caused by these vesicle neurotransmitter packets.

The first part of my $\mathrm{PhD}$ thesis deals with the ultrastructural differences between rodent and human cortical synapses using light- and electron microscopic techniques.

Pyramidal cells of the cerebral cortex excite local inhibitory interneurons via their glutamatergic axon terminals. Over the past decades several studies were performed to elucidate the workings of these connections in rodents, the most commonly used model animals. The excitatory postsynaptic potentials evoked by these connections in the rodent cortex have an average amplitude of 1 to $4 \mathrm{mV}$, which is hardly enough to drive the postsynaptic interneuron to fire action potentials. As opposed to that, these connections are far more efficient in the human cerebral cortex: a single action potential in the presynaptic pyramidal cell is sufficient to depolarize the surrounding fast spiking axo-axonic and basket cells above their firing threshold. Single action potentials of human neurons are sufficient to recruit Hebbian-like neuronal assemblies that are proposed to participate in cognitive processes.

Our high resolution EM analysis identified species-specific differences in the AZ area, the number of docked vesicles and the volume of presynaptic excitatory boutons terminating on supragranular basket cells. The human AZs were on average twice as large, furthermore, 
when we counted docked vesicles in these AZs using the $20 \mathrm{~nm}$ thin serial section approach we found a significantly larger number in human (4.2 \pm 2.2 / AZ) compared to rats $(1.3 \pm 0.8$ / AZ), resulting in a twice as large docked vesicle density in human. Our data allowed us to provide the first estimate of the size of Katz's functional release site of cortical synapses; approximately $0.012 \mu \mathrm{m}^{2} \mathrm{AZ}$ membrane area in human and $0.025 \mu \mathrm{m}^{2}$ in rats. Thus, the space that harbors a functional release site or a docking site seems to be substantially smaller in human AZs.

The second part of my $\mathrm{PhD}$ thesis deals with the anatomical background of postpartum depression.

The hippocampus participates in the stress response, and its compromised function is a central component in the pathomechanism of major depression. Compromised hippocampal function in major depression is correlated with reduced hippocampal volume, suppressed adult hippocampal neurogenesis, and loss of spine synapses along the trisynaptic loop, and these structural impairments are all prevented/reversed by effective antidepressant treatment.

Although recent studies have demonstrated hippocampal structural modifications that are related to maternal stress and mood disorders, direct electron microscopic evidence of synaptic remodeling along the trisynaptic circuit in PPD is presently not available.

Earlier research suggests that withdrawal of female reproductive hormones creates vulnerability to stress during the postpartum period. In accordance with this theory, we have previously shown in the rat learned helplessness paradigm that withdrawal of ovarian hormones alone leads to hippocampal spine synapse loss and development of depressive behavior, but these responses are only partial and become exacerbated after exposure to inescapable stress. In line with these previous findings, the present study demonstrates that 'postpartum' stress in a hormone withdrawal model of PPD causes the loss of asymmetric spine synapses along the hippocampal trisynaptic circuit, potentially disrupting signal flow and leading to a dysfunctional hippocampus. Among several brain areas that are affected by stress and mood disorders, the hippocampus plays an important role, as it is strongly involved in learning and memory, in feed-back regulation of the stress response, and in modulating the motivation circuitries. As a result, deteriorating hippocampal function may contribute to the joint development of cognitive decline, loss of motivation, and derailed stress response, the common symptoms of PPD and major depression. On the other hand, the present study also indicates that pregnancy levels of gonadal steroids protect hippocampal spine synapses against the detrimental effects of 'postpartum' stress. Importantly, this synaptoprotection is 
associated with improved escape performance, i.e., decreased depressive behavior. These results, along with our synaptogenic hypothesis of depression, suggest that protecting spine synapses by muting the stress response and/or by curbing neuronal excitability may be valid therapeutic options for preventing and treating postpartum affective illness. 


\section{KÖSZÖNETNYILVÁNÍTÁS}

Szeretnék köszönetet mondani Dr. Hajszán Tibornak és Dr. Tamás Gábornak témavezetői munkájukért, építő kritikájukért, hasznos tanácsaikért, hogy irányításuk alatt elsajátíthattam a tudományos kutatás elvi és gyakorlati alapjait.

Köszönettel tartozom Dr. Siklós László témavezetői hozzáállásáért, segítőkészségéért és támogatásáért.

Köszönöm Dr. Rázga Zsoltnak az elektronmikroszkópiában nyújtott segítségét.

Külön szeretném megköszönni Dr. Holderith Noémi hasznos tanácsait és önzetlen segítőkészségét.

Hálával tartozom férjemnek, Marcinak, mindenért :)

Köszönettel tartozom munkatársaimnak, akik részt vettek a disszertációm alapjául szolgáló kísérletekben: Dr. Molnár Gábornak, Rózsa Marcinak, Dr. Csákvári Eszternek, Dr. Dobos Nikolettának, Huzián Orsolyának, Tóth Évának és Ábramám-Tóth Nellinek. Köszönet nekik és a labor többi jelenlegi és volt tagjának, Veketyné Váradi Margónak, Boldog Eszternek, Szemenyei Viktornak, Szemenyeiné Mikite Katalinnak, Lovas Sanyinak, Piszár Ildikónak, Dr. Komlósi Gergelynek, Dr. Oláh Szabolcsnak, Dr. Kocsis Ágnes Katalinnak, Ozsvár Attilának, Oláh Gáspárnak, Kovács Balázsnak, Averkin Róbertnek, Dr. Báldi Ritának, Dr. Braskó Csillának, Dr. Füle Miklósnak, Horváth Jánosnak, Mezei Leonának, Bakos Emőkének, Törteli Annának, Tóth Martinnak, Lákovics Rajmundnak a baráti légkörért, amit kialakítottak a laborban.

Külön szeretném megköszönni Sági Varga Kinga és Dr. Oláh-Német Orsolya baráti segítségét és ösztönzését a $\mathrm{PhD}$ munkám elkezdéséhez és befejezéséhez.

Végül szeretném megköszönni a Családom, a Lányok és a Barátok türelmét, támogatását, bátorítását és szeretetét, amivel munkámat is segítették.

Kutatási támogatások:

MB08C OTKA 81190; TÁMOP-4.2.2.A-11/1/KONV-2012-0052; TÁMOP-4.2.4.A/2-11-12012-0001; GINOP-2.3.2-15- 2016-00001; GINOP-2.3.2-15-20016-00034. 


\section{IRODALOMJEGYZÉK}

Abrahám, I., Juhász, G., Kékesi, K.A., \& Kovács, K.J. (1998) Corticosterone peak is responsible for stress-induced elevation of glutamate in the hippocampus. Stress, 2, 171181.

Ali, A.B., Deuchars, J., Pawelzik, H., \& Thomson, A.M. (1998) CA1 pyramidal to basket and bistratified cell EPSPs: dual intracellular recordings in rat hippocampal slices. $J$. Physiol., 507 ( Pt 1, 201-217.

American Psychiatric Association (2000) Diagnostic and Statistical Manual of Mental Disorders 4th Edn. American Psychiatric Association: Washington, DC.

Andersen, P., Bliss, T. V, \& Skrede, K.K. (1971) Unit analysis of hippocampal polulation spikes. Exp. brain Res., 13, 208-221.

Barden, N., Reul, J.M., \& Holsboer, F. (1995) Do antidepressants stabilize mood through actions on the hypothalamic-pituitary-adrenocortical system? Trends Neurosci., 18, 611.

Bartheld, C.S. Von, Bahney, J., \& Herculano-houzel, S. (2016) The Search for True Numbers of Neurons and Glial Cells in the Human Brain: A Review of 150 Years of Cell Counting 3895, 3865-3895.

Belmaker, R.H. (2008) The future of depression psychopharmacology. CNS Spectr., 13, 682687.

Biró, A.A., Holderith, N.B., \& Nusser, Z. (2005) Quantal size is independent of the release probability at hippocampal excitatory synapses. J. Neurosci., 25, 223-232.

Bitran, D. \& Dowd, J. a. (1996) Ovarian steroids modify the behavioral and neurochemical responses of the central benzodiazepine receptor. Psychopharmacology (Berl)., 125, 6573.

Blackstad, T.W. (1958) On the termination of some afferents to the hippocampus and fascia dentata; an experimental study in the rat. Acta Anat. (Basel)., 35, 202-214.

Bloch, M., Daly, R.C., Rubinow, D.R., Ppd, I.S., With, A., Symptoms, P.O.F., \& Or, C. (2003) Endocrine factors in the etiology of postpartum depression. Compr. Psychiatry, 44, 234-246.

Bloch, M., Schmidt, P.J., Danaceau, M., Murphy, J., Nieman, L., \& Rubinow, D.R. (2000) Effects of gonadal steroids in women with a history of postpartum depression. Am. J. Psychiatry, 157, 924-930. 
Brecht, M. (2012) Neuronal communication: firing spikes with spikes. Curr. Biol., 22, R6335.

Bridges, R.S. (1984) A quantitative analysis of the roles of dosage, sequence, and duration of estradiol and progesterone exposure in the regulation of maternal behavior in the rat. Endocrinology, 114, 930-940.

Brodmann, K. (1909) Vergleichende Lokalisationslehre der Grosshirnrinde in ihren Prinzipien dargestellt auf Grund des Zellenbaues. Leipzig J. A. Barth.,.

Brummelte, S. \& Galea, L. a M. (2010) Depression during pregnancy and postpartum: contribution of stress and ovarian hormones. Prog. Neuropsychopharmacol. Biol. Psychiatry, 34, 766-776.

Brummelte, S., Pawluski, J.L., \& Galea, L. a M. (2006) High post-partum levels of corticosterone given to dams influence postnatal hippocampal cell proliferation and behavior of offspring: A model of post-partum stress and possible depression. Horm. Behav., 50, 370-382.

Brunton, P.J., McKay, A.J., Ochedalski, T., Piastowska, A., Rebas, E., Lachowicz, A., \& Russell, J. a (2009) Central opioid inhibition of neuroendocrine stress responses in pregnancy in the rat is induced by the neurosteroid allopregnanolone. J. Neurosci., 29, 6449-6460.

Carney, R.M., Freedland, K.E., Miller, G.E., \& Jaffe, A.S. (2002) Depression as a risk factor for cardiac mortality and morbidity: a review of potential mechanisms. J. Psychosom. Res., 53, 897-902.

Chrousos, G.P., Torpy, D.J., \& Gold, P.W. (1998) Interactions between the hypothalamicpituitary-adrenal axis and the female reproductive system: clinical implications. Ann. Intern. Med., 129, 229-240.

Claiborne, B.J., Amaral, D.G., \& Cowan, W.M. (1986) A light and electron microscopic analysis of the mossy fibers of the rat dentate gyrus. J. Comp. Neurol., 246, 435-458.

Cooper, D.C., Klipec, W.D., Fowler, M.A., \& Ozkan, E.D. (2006) A role for the subiculum in the brain motivation/reward circuitry. Behav. Brain Res., 174, 225-231.

Cragg, B.G. (1967) The density of synapses and neurones in the motor and visual areas of the cerebral cortex. J. Anat., 101, 639-654.

Crawley, R. a., Dennison, K., \& Carter, C. (2003) Cognition in pregnancy and the first year post-partum. Psychol. Psychother., 76, 69-84.

Darnaudéry, M., Dutriez, I., Viltart, O., Morley-Fletcher, S., \& Maccari, S. (2004) Stress during gestation induces lasting effects on emotional reactivity of the dam rat. Behav. 
Brain Res., 153, 211-216.

Davey, H.L., Tough, S.C., Adair, C.E., \& Benzies, K.M. (2011) Risk factors for sub-clinical and major postpartum depression among a community cohort of canadian women. Matern. Child Health J., 15, 866-875.

DeFelipe, J. (2011) The evolution of the brain, the human nature of cortical circuits, and intellectual creativity. Front. Neuroanat., 5, 29.

DeFelipe, J., Alonso-Nanclares, L., \& Arellano, J.I. (2002) Microstructure of the neocortex: comparative aspects. J. Neurocytol., 31, 299-316.

DeFelipe, J. \& Fariñas, I. (1992) The pyramidal neuron of the cerebral cortex: morphological and chemical characteristics of the synaptic inputs. Prog. Neurobiol., 39, 563-607.

del Castillo, J. \& Katz, B. (1954) Quantal components of the end-plate potential. J. Physiol., 124, 560-573.

Douglas, a J., Johnstone, H. a, Wigger, a, Landgraf, R., Russell, J. a, \& Neumann, I.D. (1998) The role of endogenous opioids in neurohypophysial and hypothalamo-pituitaryadrenal axis hormone secretory responses to stress in pregnant rats. J. Endocrinol., 158, $285-293$.

Douma, S.L., Husband, C., O’Donnell, M.E., Barwin, B.N., \& Woodend, A.K. (2005) Estrogen-related mood disorders: reproductive life cycle factors. ANS. Adv. Nurs. Sci., 28, 364-375.

Duman, R.S. \& Monteggia, L.M. (2006) A Neurotrophic Model for Stress-Related Mood Disorders. Biol. Psychiatry, 59, 1116-1127.

Elston, G.N. (2003) Cortex, cognition and the cell: new insights into the pyramidal neuron and prefrontal function. Cereb. Cortex, 13, 1124-1138.

Estrada-Camarena, E., Fernández-Guasti, A., \& López-Rubalcava, C. (2004) Interaction between estrogens and antidepressants in the forced swimming test in rats. Psychopharmacology (Berl)., 173, 139-145.

Freund, T.F. \& Katona, I. (2007) Perisomatic inhibition. Neuron, 56, 33-42.

Frick, K.M., Fernandez, S.M., Bennett, J.C., Prange-Kiel, J., MacLusky, N.J., \& Leranth, C. (2004) Behavioral training interferes with the ability of gonadal hormones to increase CA1 spine synapse density in ovariectomized female rats. Eur. J. Neurosci., 19, 30263032.

Fricker, D. \& Miles, R. (2000) EPSP amplification and the precision of spike timing in hippocampal neurons. Neuron, 28, 559-569.

Frye, C.A. \& Wawrzycki, J. (2003) Effect of prenatal stress and gonadal hormone condition 
on depressive behaviors of female and male rats. Horm. Behav., 44, 319-326.

Galarreta, M. \& Hestrin, S. (1999) A network of fast-spiking cells in the neocortex connected by electrical synapses. Nature, $\mathbf{4 0 2}, 72-75$.

Galarreta, M. \& Hestrin, S. (2001) Spike transmission and synchrony detection in networks of GABAergic interneurons. Science, 292, 2295-2299.

Galea, L. a, Wide, J.K., \& Barr, a M. (2001) Estradiol alleviates depressive-like symptoms in a novel animal model of post-partum depression. Behav. Brain Res., 122, 1-9.

Gavin, N.I., Gaynes, B.N., Lohr, K.N., Meltzer-Brody, S., Gartlehner, G., \& Swinson, T. (2005) Perinatal depression: a systematic review of prevalence and incidence. Obstet. Gynecol., 106, 1071-1083.

Gemmel, M., Rayen, I., van Donkelaar, E., Loftus, T., Steinbusch, H.W., Kokras, N., Dalla, C., \& Pawluski, J.L. (2016) Gestational stress and fluoxetine treatment differentially affect plasticity, methylation and serotonin levels in the PFC and hippocampus of rat dams. Neuroscience, 327, 32-43.

Gibson, J.R., Beierlein, M., \& Connors, B.W. (1999) Two networks of electrically coupled inhibitory neurons in neocortex. Nature, 402, 75-79.

Grace, S.L., Evindar, A., \& Stewart, D.E. (2003) The effect of postpartum depression on child cognitive development and behavior: a review and critical analysis of the literature. Arch. Womens. Ment. Health, 6, 263-274.

Green, A.D. \& Galea, L.A.M. (2008) Adult hippocampal cell proliferation is suppressed with estrogen withdrawal after a hormone-simulated pregnancy. Horm. Behav., 54, 203-211.

Gregoire, A.J., Kumar, R., Everitt, B., Henderson, A.F., \& Studd, J.W. (1996) Transdermal oestrogen for treatment of severe postnatal depression. Lancet (London, England), 347, 930-933.

Grota, L.J. \& Eik-Nes, K.B. (1967) Plasma progesterone concentrations during pregnancy and lactation in the rat. J. Reprod. Fertil., 13, 83-91.

Gulyás, A.I., Miles, R., Sík, A., Tóth, K., Tamamaki, N., \& Freund, T.F. (1993) Hippocampal pyramidal cells excite inhibitory neurons through a single release site. Nature, 366, 683687.

Hagmann, P., Cammoun, L., Gigandet, X., Meuli, R., Honey, C.J., Wedeen, V.J., \& Sporns, O. (2008) Mapping the structural core of human cerebral cortex. PLoS Biol., 6, e159.

Haim, A., Albin-Brooks, C., Sherer, M., Mills, E., \& Leuner, B. (2016) The effects of gestational stress and Selective Serotonin reuptake inhibitor antidepressant treatment on structural plasticity in the postpartum brain--A translational model for postpartum 
depression. Horm. Behav., 77, 124-131.

Hajszan, T., Dow, A., Warner-Schmidt, J.L., Szigeti-Buck, K., Sallam, N.L., Parducz, A., Leranth, C., \& Duman, R.S. (2009) Remodeling of hippocampal spine synapses in the rat learned helplessness model of depression. Biol. Psychiatry, 65, 392-400.

Hajszan, T., Szigeti-Buck, K., Sallam, N., \& Bober, J. (2010) Effects of estradiol on learned helplessness and associated remodeling of hippocampal spine synapses in female rats. Biological, 67, 168-174.

Hebb, D.O. (1949) The organization of behavior. New York Wiley Sons, .

Heidrich, A., Schleyer, M., Spingler, H., Albert, P., Knoche, M., Fritze, J., \& Lanczik, M. (1994) Postpartum blues: relationship between not-protein bound steroid hormones in plasma and postpartum mood changes. J. Affect. Disord., 30, 93-98.

Hendrick, V., Altshuler, L.L., \& Suri, R. (1998) Hormonal changes in the postpartum and implications for postpartum depression. Psychosomatics, 39, 93-101.

Herculano-Houzel, S. (2009) The human brain in numbers: a linearly scaled-up primate brain. Front. Hum. Neurosci., 3, 31.

Hillerer, K.M., Neumann, I.D., Couillard-Despres, S., Aigner, L., \& Slattery, D.A. (2014) Lactation-induced reduction in hippocampal neurogenesis is reversed by repeated stress exposure. Hippocampus, 24, 673-683.

Hillerer, K.M., Neumann, I.D., \& Slattery, D.A. (2012) From stress to postpartum mood and anxiety disorders: how chronic peripartum stress can impair maternal adaptations. Neuroendocrinology, 95, 22-38.

Hillerer, K.M., Reber, S.O., Neumann, I.D., \& Slattery, D.A. (2011) Exposure to chronic pregnancy stress reverses peripartum-associated adaptations: implications for postpartum anxiety and mood disorders. Endocrinology, 152, 3930-3940.

Holmgren, C., Harkany, T., Svennenfors, B., \& Zilberter, Y. (2003) Pyramidal cell communication within local networks in layer $2 / 3$ of rat neocortex. J. Physiol., 551, 139153.

Kang, H.J., Voleti, B., Hajszan, T., Rajkowska, G., Stockmeier, C. a, Licznerski, P., Lepack, A., Majik, M.S., Jeong, L.S., Banasr, M., Son, H., \& Duman, R.S. (2012) Decreased expression of synapse-related genes and loss of synapses in major depressive disorder. Nat. Med., 1-7.

Kanner, A.M. (2005) Depression and the risk of neurological disorders. Lancet (London, England), 366, 1147-1148.

Kant, G.J., Leu, J.R., Anderson, S.M., \& Mougey, E.H. (1987) Effects of chronic stress on 
plasma corticosterone, ACTH and prolactin. Physiol. Behav., 40, 775-779.

Kawaguchi, Y. (1993) Groupings of nonpyramidal and pyramidal cells with specific physiological and morphological characteristics in rat frontal cortex. J. Neurophysiol., 69, 416-431.

Kawaguchi, Y. \& Kubota, Y. (1993) Correlation of physiological subgroupings of nonpyramidal cells with parvalbumin- and calbindinD28k-immunoreactive neurons in layer V of rat frontal cortex. J. Neurophysiol., 70, 387-396.

Kawaguchi, Y. \& Kubota, Y. (1996) Physiological and morphological identification of somatostatin- or vasoactive intestinal polypeptide-containing cells among GABAergic cell subtypes in rat frontal cortex. J. Neurosci., 16, 2701-2715.

Kawaguchi, Y. \& Kubota, Y. (1997) GABAergic cell subtypes and their synaptic connections in rat frontal cortex. Cereb. Cortex, 7, 476-486.

Kendler, K.S., Karkowski, L.M., \& Prescott, C.A. (1999) Causal relationship between stressful life events and the onset of major depression. Am. J. Psychiatry, 156, 837-841.

Kessler, R.C., McGonagle, K.A., Zhao, S., Nelson, C.B., Hughes, M., Eshleman, S., Wittchen, H.U., \& Kendler, K.S. (1994) Lifetime and 12-month prevalence of DSM-III$\mathrm{R}$ psychiatric disorders in the United States. Results from the National Comorbidity Survey. Arch. Gen. Psychiatry, 51, 8-19.

Kisvárday, Z.F., Beaulieu, C., \& Eysel, U.T. (1993) Network of GABAergic large basket cells in cat visual cortex (area 18): implication for lateral disinhibition. J. Comp. Neurol., 327, $398-415$.

Klier, C.M., Muzik, M., Dervic, K., Mossaheb, N., Benesch, T., Ulm, B., \& Zeller, M. (2007) The role of estrogen and progesterone in depression after birth. J. Psychiatr. Res., 41, $273-279$.

Komlósi, G., Molnár, G., Rózsa, M., Oláh, S., Barzó, P., \& Tamás, G. (2012) Fluoxetine (prozac) and serotonin act on excitatory synaptic transmission to suppress single layer 2/3 pyramidal neuron-triggered cell assemblies in the human prefrontal cortex. $J$. Neurosci., 32, 16369-16378.

Korn, H., Mallet, A., Triller, A., \& Faber, D.S. (1982) Transmission at a central inhibitory synapse. II. Quantal description of release, with a physical correlate for binomial n. $J$. Neurophysiol., 48, 679-707.

Lancaster, C.A., Gold, K.J., Flynn, H.A., Yoo, H., Marcus, S.M., \& Davis, M.M. (2010) Risk factors for depressive symptoms during pregnancy: a systematic review. Am. J. Obstet. Gynecol., 202, 5-14. 
Laura J. Miller, M. (2002) Postpartum Depression. JAMA, 287, 11-14.

Leranth, C., Hajszan, T., Szigeti-Buck, K., Bober, J., \& MacLusky, N.J. (2008) Bisphenol A prevents the synaptogenic response to estradiol in hippocampus and prefrontal cortex of ovariectomized nonhuman primates. Proc. Natl. Acad. Sci. U. S. A., 105, 14187-14191.

Letourneau, N.L., Dennis, C.-L., Benzies, K., Duffett-Leger, L., Stewart, M., Tryphonopoulos, P.D., Este, D., \& Watson, W. (2012) Postpartum depression is a family affair: addressing the impact on mothers, fathers, and children. Issues Ment. Health Nurs., 33, 445-457.

Leuner, B., Fredericks, P.J., Nealer, C., \& Albin-Brooks, C. (2014) Chronic gestational stress leads to depressive-like behavior and compromises medial prefrontal cortex structure and function during the postpartum period. PLoS One, 9, e89912.

Lisman, J.E. \& Grace, A.A. (2005) The hippocampal-VTA loop: controlling the entry of information into long-term memory. Neuron, 46, 703-713.

Loomer, H.P., Saunders, J.C., \& Kline, N.S. (1957) A clinical and pharmacodynamic evaluation of iproniazid as a psychic energizer. Psychiatr. Res. Rep. Am. Psychiatr. Assoc., 8, 129-141.

Lowy, M.T., Gault, L., \& Yamamoto, B.K. (1993) Rapid Communication: Adrenalectomy Attenuates Stress-Induced Elevations in Extracellular Glutamate Concentrations in the Hippocampus. J. Neurochem., 61, 1957-1960.

Maguire, J. \& Mody, I. (2008) GABA(A)R plasticity during pregnancy: relevance to postpartum depression. Neuron, 59, 207-213.

Manji, H.K., Drevets, W.C., \& Charney, D.S. (2001) The cellular neurobiology of depression. Nat. Med., 7, 541-547.

Markram, H., Toledo-Rodriguez, M., Wang, Y., Gupta, A., Silberberg, G., \& Wu, C. (2004) Interneurons of the neocortical inhibitory system. Nat. Rev. Neurosci., 5, 793-807.

McEwen, B.S. (2003) Mood disorders and allostatic load. Biol. Psychiatry, 54, 200-207.

McNeilly, A.S. (2001) Neuroendocrine changes and fertility in breast-feeding women. Prog. Brain Res., 133, 207-214.

Melges, F.T. (1968) Postpartum psychiatric syndromes. Psychosom. Med., 30, 95-108.

Molnár, G., Oláh, S., Komlósi, G., Füle, M., Szabadics, J., Varga, C., Barzó, P., \& Tamás, G. (2008) Complex events initiated by individual spikes in the human cerebral cortex. PLoS Biol., 6, e222.

Moses-Kolko, E.L., Horner, M.S., Phillips, M.L., Hipwell, A.E., \& Swain, J.E. (2014) In search of neural endophenotypes of postpartum psychopathology and disrupted maternal 
caregiving. J. Neuroendocrinol., 26, 665-684.

Mostallino, M.C., Sanna, E., Concas, A., Biggio, G., \& Follesa, P. (2009) Plasticity and function of extrasynaptic $\operatorname{GABA}(\mathrm{A})$ receptors during pregnancy and after delivery. Psychoneuroendocrinology, 34 Suppl 1, S74-83.

Mountcastle, V.B. (1997) The columnar organization of the neocortex. Brain, 120 ( Pt 4, 701-722.

Nemeroff, C.B. \& Owens, M.J. (2004) Pharmacologic differences among the SSRIs: focus on monoamine transporters and the HPA axis. CNS Spectr., 9, 23-31.

Nestler, E.J., Barrot, M., Dileone, R.J., Eisch, A.J., Gold, S.J., \& Monteggia, L.M. (2002) Neurobiology of Depression Review 34, 13-25.

Nomura, Y., Wickramaratne, P.J., Warner, V., Mufson, L., \& Weissman, M.M. (2006) Family discord, parental depression, and psychopathology in offspring: 20-year follow-up. $J$. Am. Acad. Child Adolesc. Psychiatry, 45, 452-460.

O’Hara, M.W. \& Wisner, K.L. (2014) Perinatal mental illness: definition, description and aetiology. Best Pract. Res. Clin. Obstet. Gynaecol., 28, 3-12.

O’Mahony, S.M., Myint, A.-M., van den Hove, D., Desbonnet, L., Steinbusch, H., \& Leonard, B.E. (2006) Gestational stress leads to depressive-like behavioural and immunological changes in the rat. Neuroimmunomodulation, 13, 82-88.

Oláh, S., Füle, M., Komlósi, G., Varga, C., Báldi, R., Barzó, P., \& Tamás, G. (2009) Regulation of cortical microcircuits by unitary GABA-mediated volume transmission. Nature, 461, 1278-1281.

Palucha, A. \& Pilc, A. (2005) The involvement of glutamate in the pathophysiology of depression. Drug News Perspect., 18, 262-268.

Pariser, S.F., Nasrallah, H.A., \& Gardner, D.K. (1997) Postpartum mood disorders: clinical perspectives. J. women's Heal., 6, 421-434.

Park, H.-J. \& Friston, K. (2013) Structural and functional brain networks: from connections to cognition. Science, 342, 1238411.

Parry, B.L., Sorenson, D.L., Meliska, C.J., Basavaraj, N., Zirpoli, G.G., Gamst, A., \& Hauger, R. (2003) Hormonal basis of mood and postpartum disorders. Curr. Womens. Health Rep., 3, 230-235.

Pawluski, J.L., Császár, E., Savage, E., Martinez-Claros, M., Steinbusch, H.W.M., \& van den Hove, D. (2015) Effects of stress early in gestation on hippocampal neurogenesis and glucocorticoid receptor density in pregnant rats. Neuroscience, 290, 379-388.

Pawluski, J.L., Lambert, K.G., \& Kinsley, C.H. (2016) Neuroplasticity in the maternal 
hippocampus: Relation to cognition and effects of repeated stress. Horm. Behav., 77, 8697.

Pawluski, J.L., Rayen, I., Niessen, N. a, Kristensen, S., van Donkelaar, E.L., Balthazart, J., Steinbusch, H.W., \& Charlier, T.D. (2012) Developmental fluoxetine exposure differentially alters central and peripheral measures of the HPA system in adolescent male and female offspring. Neuroscience, 220, 131-141.

Pepe, G.J. \& Rothchild, I. (1974) A comparative study of serum progesterone levels in pregnancy and in various types of pseudopregnancy in the rat. Endocrinology, 95, 275279.

Pitt, B. (1968) “Atypical” Depression Following Childbirth. Br. J. Psychiatry, 114, 13251335.

Price, J.L. \& Drevets, W.C. (2010) Neurocircuitry of mood disorders. Neuropsychopharmacology, 35, 192-216.

Rachman, I.M., Unnerstall, J.R., Pfaff, D.W., \& Cohen, R.S. (1998) Estrogen alters behavior and forebrain c-fos expression in ovariectomized rats subjected to the forced swim test. Proc. Natl. Acad. Sci. U. S. A., 95, 13941-13946.

Ramón y Cajal, S. (1904) Textura del systema nervioso del hombre y los vertebrados. In. Madrid, Spain Moya,

Ramón y Cajal, S. (1911) Histologie du systeme nerveux de l'homme et des vertebres. Paris: Maloine,

Rubinow, D.R. \& Schmidt, P.J. (2006) Gonadal steroid regulation of mood: the lessons of premenstrual syndrome. Front. Neuroendocrinol., 27, 210-216.

Rudolph, S., Tsai, M.-C., von Gersdorff, H., \& Wadiche, J.I. (2015) The ubiquitous nature of multivesicular release. Trends Neurosci., 38, 428-438.

Schmidt, P.J. \& Rubinow, D.R. (2009) Sex hormones and mood in the perimenopause. Ann. N. Y. Acad. Sci., 1179, 70-85.

Segal, M. (1995) Morphological alterations in dendritic spines of rat hippocampal neurons exposed to N-methyl-D-aspartate. Neurosci. Lett., 193, 73-76.

Sheline, Y.I., Gado, M.H., \& Kraemer, H.C. (2003) Untreated depression and hippocampal volume loss. Am. J. Psychiatry, 160, 1516-1518.

Shepherd, G.M. (2004) The organization of the Brain. New York Oxford Univ. Press,.

Sichel, D.A., Cohen, L.S., Robertson, L.M., Ruttenberg, A., \& Rosenbaum, J.F. (1995) Prophylactic estrogen in recurrent postpartum affective disorder. Biol. Psychiatry, 38, $814-818$. 
Silver, R.A. (2003) Estimation of nonuniform quantal parameters with multiple-probability fluctuation analysis: theory, application and limitations. J. Neurosci. Methods, 130, 127141.

Slattery, D.A. \& Neumann, I.D. (2008) No stress please! Mechanisms of stress hyporesponsiveness of the maternal brain. J. Physiol., 586, 377-385.

Sloper, J.J., Hiorns, R.W., \& Powell, T.P. (1979) A qualitative and quantitative electron microscopic study of the neurons in the primate motor and somatic sensory cortices. Philos. Trans. R. Soc. Lond. B. Biol. Sci., 285, 141-171.

Smith, J.W., Seckl, J.R., Evans, A.T., Costall, B., \& Smythe, J.W. (2004) Gestational stress induces post-partum depression-like behaviour and alters maternal care in rats. Psychoneuroendocrinology, 29, 227-244.

Somogyi, P., Kisvárday, Z.F., Martin, K.A., \& Whitteridge, D. (1983) Synaptic connections of morphologically identified and physiologically characterized large basket cells in the striate cortex of cat. Neuroscience, 10, 261-294.

Somogyi, P., Tamás, G., Lujan, R., \& Buhl, E.H. (1998) Salient features of synaptic organisation in the cerebral cortex. Brain Res. Brain Res. Rev., 26, 113-135.

Sousa, N., Lukoyanov, N. V., Madeira, M.D., Almeida, O.F.X., \& Paula-Barbosa, M.M. (2000) Reorganization of the morphology of hippocampal neurites and synapses after stress-induced damage correlates with behavioral improvement. Neuroscience, 97, 253266.

Spinelli, M.G. (2004) Maternal infanticide associated with mental illness: prevention and the promise of saved lives. Am. J. Psychiatry, 161, 1548-1557.

Steiner, M., Dunn, E., \& Born, L. (2003) Hormones and mood: from menarche to menopause and beyond. J. Affect. Disord., 74, 67-83.

Stell, B.M., Brickley, S.G., Tang, C.Y., Farrant, M., \& Mody, I. (2003) Neuroactive steroids reduce neuronal excitability by selectively enhancing tonic inhibition mediated by delta subunit-containing GABAA receptors. Proc. Natl. Acad. Sci. U. S. A., 100, 1443914444.

Sterio, D.C. (1984) The unbiased estimation of number and sizes of arbitrary particles using the disector. J. Microsc., 134, 127-136.

Stewart, D.E. (2011) Clinical practice. Depression during pregnancy. N. Engl. J. Med., 365, $1605-1611$.

Stoffel, E.C. \& Craft, R.M. (2004) Ovarian hormone withdrawal-induced "depression" in female rats. Physiol. Behav., 83, 505-513. 
Studd, J. \& Panay, N. (2004) Hormones and depression in women. Climacteric, 7, 338-346.

Suda, S., Segi-Nishida, E., Newton, S.S., \& Duman, R.S. (2008) A postpartum model in rat: behavioral and gene expression changes induced by ovarian steroid deprivation. Biol. Psychiatry, 64, 311-319.

Szabadics, J., Varga, C., Molnár, G., Oláh, S., Barzó, P., \& Tamás, G. (2006) Excitatory effect of GABAergic axo-axonic cells in cortical microcircuits. Science, 311, 233-235.

Szegedi, V., Paizs, M., Csakvari, E., Molnar, G., Barzo, P., Tamas, G., \& Lamsa, K. (2016) Plasticity in Single Axon Glutamatergic Connection to GABAergic Interneurons Regulates Complex Events in the Human Neocortex. PLoS Biol., 14, e2000237.

Tamás, G., Buhl, E.H., Lörincz, a, \& Somogyi, P. (2000) Proximally targeted GABAergic synapses and gap junctions synchronize cortical interneurons. Nat. Neurosci., 3, 366371.

Tamás, G., Szabadics, J., Lörincz, A., \& Somogyi, P. (2004) Input and frequency-specific entrainment of postsynaptic firing by IPSPs of perisomatic or dendritic origin. Eur. $J$. Neurosci., 20, 2681-2690.

Tang, Y., Nyengaard, J.R., De Groot, D.M., \& Gundersen, H.J. (2001) Total regional and global number of synapses in the human brain neocortex. Synapse, 41, 258-273.

Trivedi, M.H., Rush, A.J., Wisniewski, S.R., Nierenberg, A.A., Warden, D., Ritz, L., Norquist, G., Howland, R.H., Lebowitz, B., McGrath, P.J., Shores-Wilson, K., Biggs, M.M., Balasubramani, G.K., \& Fava, M. (2006) Evaluation of outcomes with citalopram for depression using measurement-based care in STAR*D: Implications for clinical practice. Am. J. Psychiatry, 163, 28-40.

Verbeek, T., Bockting, C.L.H., van Pampus, M.G., Ormel, J., Meijer, J.L., Hartman, C.A., \& Burger, H. (2012) Postpartum depression predicts offspring mental health problems in adolescence independently of parental lifetime psychopathology. J. Affect. Disord., 136, 948-954.

Wartella, J., Amory, E., Macbeth, A., McNamara, I., Stevens, L., Lambert, K.G., \& Kinsley, C.H. (2003) Single or multiple reproductive experiences attenuate neurobehavioral stress and fear responses in the female rat. Physiol. Behav., 79, 373-381.

Winfield, D.A., Gatter, K.C., \& Powell, T.P. (1980) An electron microscopic study of the types and proportions of neurons in the cortex of the motor and visual areas of the cat and rat. Brain, 103, 245-258.

Witter, M.P. (1993) Organization of the entorhinal-hippocampal system: a review of current anatomical data. Hippocampus, 3 Spec No, 33-44. 
Woolley, C.S. \& McEwen, B.S. (1992) Estradiol mediates fluctuation in hippocampal synapse density during the estrous cycle in the adult rat. J. Neurosci., 12, 2549-2554.

Wu, L.-X., Sun, C.-K., Zhang, Y.-M., Fan, M., Xu, J., Ma, H., \& Zhang, J. (2007) Involvement of the Snk-SPAR pathway in glutamate-induced excitotoxicity in cultured hippocampal neurons. Brain Res., 1168, 38-45.

Zhang, B., Koh, Y.H., Beckstead, R.B., Budnik, V., Ganetzky, B., \& Bellen, H.J. (1998) Synaptic vesicle size and number are regulated by a clathrin adaptor protein required for endocytosis. Neuron, 21, 1465-1475. 